\title{
Sintiencia animal: Necesidad de un reconocimiento jurídico material, y sus implicaciones teóricas y prácticas
}

\author{
Juan Diego Valdés Rocha \\ MA Derecho Animal y Sociedad (UAB) \\ J.R.A.A. Abogados Asociados, Bogotá, Colombia \\ https://orcid.org/0000-0002-3143-8991
}

Cita recomendada. VALDÉS ROCHA, J.D., Sintiencia animal: Necesidad de un reconocimiento jurídico material, y sus implicaciones teóricas y prácticas, dA. Derecho Animal (Forum of Animal Law Studies) 12/3 (2021). - DOI https://doi.org/10.5565/rev/da.575

\section{Resumen}

Los animales no humanos que ostentan la calidad de seres sintientes, son sujetos de consideración moral y, por tanto, titulares de derechos morales. Esto debe reflejarse en el mundo del derecho, que debe reconocer jurídicamente esa sintiencia, lo que hace necesaria la edificación una categoría jurídica propia para ellos, que los defina jurídicamente, y les reconozca unos derechos mínimos inviolables que se derivan, necesariamente, de la condición biológica de seres sintientes, a saber: el derecho a la vida, a la libertad, a la integridad y a la dignidad. Para sustentar lo anterior, estudiamos el concepto de sintiencia y sus implicaciones, de manera general, para luego hacerlo desde el punto de vista jurídico, para lo que se hace un repaso sobre los conceptos de persona y sujeto de derecho, a efectos de verificar la idoneidad, o no, de estos para incluir a los animales no humanos. Posteriormente hacemos un análisis jurisprudencial sobre la materia en distintos países, para luego revisar el caso concreto de la legislación y jurisprudencia colombiana. Finalmente, exponemos algunas consecuencias prácticas que debería tener el reconocimiento jurídico de la sintiencia de los animales no humanos, con relación a actividades que implican su explotación, y señalamos ciertos elementos de las relaciones laborales entre humanos que pueden extrapolarse a algunas de las relaciones existentes entre los seres humanos y otros animales, y, a partir de ello, planteamos la posibilidad de la creación de un sistema de seguridad social que cubra las contingencias a las que pueden verse sometidos algunos animales con fundamento en estas relaciones.

Palabras clave: Sintiencia; sujeto de derecho; persona; personalidad jurídica; derechos de los animales; moral; explotación; especismo; animales no humanos.

Abstract - Animal sentience: the need for material legal recognition, and the theoretical and practical implications

Nonhuman animals qualified as sentient beings are subjects of moral consideration and are therefore holders of moral rights. This must be recognized in the legal world, which must legally recognize such sentience, making it necessary to construct a legal category specifically for them that legal defines them and recognizes minimum inviolable rights that necessarily derive from the biological condition of sentient beings, which are the right to life, to freedom, to integrity and to dignity. To support this point, we study the concept of sentience and its implications generally in order to then do so from a legal perspective, for which we re-examine the concepts of person and legal subject, to the effect of verifying their suitability, or lack of, for including 
nonhuman animals. Subsequently, we make a jurisprudential analysis of this subject in different countries in order to then review the specific case of Colombian legislation and jurisprudence. Lastly, point out certain practical consequences of nonhuman animal sentience relating to activities that entail their exploitation that should have legal consequences, and point out certain elements of working relations between humans that could be extrapolated to certain existing relations between human beings and other animals and, aside from this, we propose the possibility of creating a social security system that covers the contingencies that certain animals could be subjected to due to such relations.

Keywords: sentience; subject of law; person; legal personhood; animal rights; moral; exploitation; speciesism; non-human animals.

\section{Índice de Abreviaturas}

DRAE: Diccionario De La Real Academia Española

RAE: Real Academia Española

TFUE: Tratado De Funcionamiento De La Unión Europea.

OIE: Organización Mundial de Sanidad Animal ("Office International des Epizooties").

FAO: Organización de las Naciones Unidas para la Alimentación y la Agricultura.

\section{Introducción}

Los animales no humanos, hoy en día, son utilizados por el ser humano, en muchos casos, como simples objetos y, asimismo en ocasiones son explotados y matados sin consideración alguna para satisfacer caprichos humanos, y no necesidades. El Derecho, como ciencia inescindible de la sociedad humana, juega un importante rol y, en múltiples ocasiones, en vez de ser un elemento tutelar de los animales, se ha convertido en un mecanismo para garantizar y perpetuar su explotación. Hoy en día, existen nuevas realidades, que obedecen a importantes avances científicos y sociales, a los cuales el Derecho debe ofrecer una regulación. Hasta el día de hoy, los animales son considerados jurídicamente como cosas, y así mismo se les trata, bajo el manto de protección y legitimidad que para ello otorga el Derecho, aunque los avances científicos apunten en otra dirección.

Los avances en las ciencias naturales han llevado al reconocimiento en ese ámbito de la sentiencia, o sintiencia, de los animales no humanos, lo que a la vez ha repercutido en cuestionamientos de índole moral sobre el trato y el relacionamiento con los animales no humanos. En este marco de progreso científico y social, es mandatorio que el derecho haga lo propio, que avance en el sentido que marcan las ciencias naturales y los movimientos sociales, en beneficio de los animales no humanos y les reconozca como seres sintientes, con derechos, y no como cosas.

Es evidente que siempre ha habido personas y grupos preocupados por los animales, y en el mundo jurídico ha habido muchos avances que se han dado de forma paulatina desde hace algún tiempo, y no solo recientemente, aunque tal vez es en los últimos 200 años (a partir de la expedición del "Martin's Act" en 1822) cuando se ha visto un auge en las normas de protección de los animales (lento, pero creciente). Recientemente vemos avances legislativos, así como jurisprudenciales, pero muchas veces se evidencia la dificultad de proteger a los animales debido a las rígidas formas del derecho, y, por tanto, se ha optado por el uso de analogías y por la extensión de categorías jurídicas que no se ajustan propiamente a las características de los animales para defenderlos, lo que ha demostrado ser una tarea difícil y muchas veces infructuosa.

Es necesario que el derecho siga el camino marcado por el avance científico y social, que se plantee consideraciones de índole ética, y se tome la sintiencia de los animales no humanos en serio, que se dejen de lado los intereses económicos y el egoísmo, y se les incluya, verdaderamente, a través del derecho, en círculo de consideración moral, para darles la protección y el trato que corresponde.

\subsection{Tesis:}


Los animales no humanos que ostentan la calidad de seres sintientes, de conformidad con la evidencia científica, son sujetos de consideración moral y, por tanto, titulares de derechos morales. Esto debe reflejarse en el mundo del derecho, el cual debe ajustarse a los avances sociales y científicos y, por lo tanto, debe dar el paso de reconocer jurídicamente la sintiencia de estos, como ya se hace en algunas legislaciones. Sin embargo, un reconocimiento jurídico de la sintiencia, sin concesión de derechos, es un reconocimiento meramente formal, incompleto, por lo que, a partir del estatus de seres sintientes de los animales no humanos, se debe edificar una categoría jurídica propia para aquellos, que les defina jurídicamente, y que les reconozca unos derechos mínimos inviolables que se derivan, necesariamente, de la condición biológica de seres sintientes. Además de esta serie de derechos mínimos, deben reconocerse otros derechos a los animales con base en sus características particulares (las de su especie), sus necesidades y, también, según el tipo de relaciones que tengan con los seres humanos.

\subsection{Objetivos que se pretenden alcanzar:}

Plantear que el derecho debe seguir el camino señalado por las ciencias naturales y por los avances sociales y, por lo tanto, debe reconocer la sintiencia de los animales no humanos. Así mismo, pretendo señalar que este reconocimiento debe implicar un respeto absoluto por la vida de aquellos, por cuanto, en su condición de seres sintientes, tienen un interés en vivir, por lo que el derecho no puede limitarse a declarar la sintiencia, sino que, si pretende tener un mínimo nivel de coherencia, debe proteger a los seres que la ostentan, reconociéndoles derechos que sean inviolables, que considero deben ser los derechos a la vida, a la libertad, a la dignidad y a la integridad.

\subsection{Razón de la elección del tema en cuestión:}

Considero que los seres humanos maltratamos y explotamos a los animales no-humanos sin necesidad alguna, por egoísmo e intereses económicos, y les quitamos casi cualquier consideración de tipo moral según sea necesario, para justificar la explotación a la que sometemos a cada especie, según lo creamos conveniente (para justificar la práctica en cuestión, sí, pero también para no sentir culpabilidad), y esta es una situación insostenible en una sociedad que pretenda progresar, por cuanto el progreso, en mi opinión, no puede tener como única medida el crecimiento económico sino que debe tener como guía -y objetivo- el progreso moral.

Por lo anterior, considero que es necesario un cambio radical en la forma en que los humanos nos relacionamos con los demás animales. Un cambio de esta naturaleza debe conllevar el reconocimiento de los animales como seres de consideración moral, aparejado de la concesión de derechos para aquellos, lo cual implica, a su turno, tratarles como un fin, y no como medios para satisfacer caprichos e intereses económicos de los seres humanos, y aunque la inclusión de los animales tiene cada vez mayor apoyo dentro de las sociedades humanas, es necesario que el derecho haga parte de este cambio, de esta revolución, si se quiere, y que deje de ser un mecanismo que se presta para la explotación de los animales no humanos y, por el contrario, se convierta en un elemento y una herramienta de cambio y de protección para aquellos, para lo cual debe cambiar el enfoque desde el que se aborda el tema de los animales, pasando de un enfoque antropocéntrico, a uno que tenga como eje a los animales y sus intereses.

\section{Sintiencia: Concepto e implicaciones.}

A lo largo de este trabajo usaré los términos sintiencia y sintiente, aunque en la doctrina se utilicen también los términos sentiencia y sentiente, como se expondrá más adelante. Ahora bien, como señala la profesora Giménez-Candela, "La Ciencia del Bienestar Animal, ha cumplido acabadamente — durante muchos años- el papel de investigar los intereses de los animales como "seres sentientes", expresión esta procedente del mundo de las Ciencias relativas a los animales y el medio ambiente, que se ha integrado dentro del mundo jurídico como expresión del grado de tratamiento y protección de los animales, de forma que el sistema jurídico parece haberla ya hecho suya, a pesar de que ni el término sentiencia/sintiencia, ni la expresión seres sentientes/sintientes figure aún en el Diccionario de la RAE"1.

El concepto de sintiencia (o sentiencia) presenta, desde su definición, algunas dificultades en la medida en que, como se señaló en la cita anterior, este término no está reconocido en el Diccionario de la Real Academia Española (DRAE). Al hacer referencia a este concepto en inglés se utiliza el término sentience que es, de acuerdo con el diccionario de Cambridge "The quality of being able to experience feelings", es decir,

${ }^{1}$ GIMÉNEZ-CANDELA, M. Transición Animal en España (Valencia 2020) 158. 
la cualidad de ser capaz de experimentar sensaciones ${ }^{2}$. Sin embargo, la traducción al español del término sentient es "sensible" (así se encuentra, por ejemplo, en el texto en español del artículo 13 del Tratado de Funcionamiento de la Unión Europea), que se define, de acuerdo con el DRAE así: "Dicho de un ser vivo o de uno de sus órganos: capaz de experimentar sensaciones".

Sin embargo, en español, la palabra "sensibles" puede referirse también a cosas o seres inanimados, como señala Enrique Alonso, quien afirma que, "Hay cosas o seres inanimados que son sensibles (a la erosión, a la luz.) y nadie duda que las plantas son seres sensibles (de nuevo, a la luz, a la humedad...). Es obvio que en el Tratado [TFUE] se ha querido expresar algo muy distinto y que solo es aplicable a los animales" 3 . En ese sentido, es posible considerar que la palabra "sensibles" no es la más adecuada para plasmar lo que se quiere expresar cuando se hace referencia a la capacidad y facultad de los animales de sentir, de experimentar sensaciones, tanto en el ámbito físico como en el psicológico, y a la consciencia que tienen estos de sí mismos, por cuanto parece quedarse corto el término y, por tanto, al referirse a esto, la doctrina y la legislación han adoptado los términos sintiencia o sentiencia.

Como ya se señaló, los vocablos sintiencia y sentiencia no están reconocidos por la RAE. Sin embargo, al buscar la definición de la palabra "sentir" en el Diccionario Panhispánico de Dudas de la Real Academia Española (RAE) se obtiene el siguiente resultado: "4. Pertenece a la familia de este verbo el adjetivo sentiente ('que siente'), forma que deriva directamente del latín sentiens, -entis (participio de presente de sentire) y es la preferida en el uso culto: «La energía estimular solo es potencialmente estimulante; para que de hecho estimule precisa del otro término de la relación, el organismo sentiente» (Pinillos Psicología [Esp. 1975]). No obstante, la variación vocálica que el verbo sentir presenta en su raíz — sentimos, sintió - ha favorecido la creación de la variante sintiente, también válida: «Ponen especial énfasis en no dañar a ningún ser sintiente» (Calle Yoga [Esp. 1990])” (Negrita fuera del texto).

En ese sentido, y de acuerdo con lo que se ha dicho, se ha optado por la doctrina y la literatura jurídica, así como por la legislación en algunos casos, por utilizar los términos sintiencia o sentiencia (o los adjetivos correspondientes sintiente y sentiente), en vez de sensibilidad (o el adjetivo "sensible"), siendo estos, además, términos utilizados, como ya se dijo, por las ciencias relativas a los animales y el medio ambiente.

\subsection{Definición doctrinal de la sintiencia}

Siguiendo con lo señalado por Enrique Alonso, la sintiencia es "tener la habilidad de experimentar dolor y sufrimiento físico o psicológico porque tienen [los animales] un sistema nervioso y un cerebro desarrollado"4. Por otra parte, Peter Singer define la sintiencia ("sentience") como "la capacidad de sufrir o experimentar gozo o felicidad" 56 mientras que Gary Francione señala que la sintiencia es una característica que permite a los seres que la poseen identificar situaciones que son dañinas y que amenazan su supervivencia $y$, en ese sentido, es también un medio para alcanzar el fin de una existencia continuada. Los seres sintientes, en virtud de tal característica, tienen un interés en permanecer vivos. Adicionalmente, Francione señala que, de conformidad con el biólogo Donald Griffin, puede entenderse que cualquier ser sintiente es consciente de sí mismo ${ }^{7}$ en la medida en que ser sintiente significa ser la clase de ser que reconoce que es precisamente este, y no otro ser, el que experimenta dolor o angustia ${ }^{8}$. En esa medida, cuando un ser siente dolor, ese ser reconoce que es quien siente ese dolor, y en ese sentido, hay alguien que es consciente de sentir dolor y tiene interés en no experimentarlo más ${ }^{9}$. Finalmente, es relevante señalar que la sintiencia es, por supuesto, común entre los animales humanos y no humanos, y que, de acuerdo con Xavier Zubiri, el sentir es un proceso, compuesto por una serie de momentos esenciales, que "constituye lo específico de la animalidad" 10 .

\footnotetext{
${ }^{2}$ Se hace la traducción de "feelings" como sensaciones, y no como "sentimientos", en la medida en que el mismo diccionario define "feeling" como "the fact of feeling something physical" y señala como sinónimo de "feeling" la palabra "sensation" (sensación), por lo que se considero se entiende que "sentience" hace referencia a la capacidad de experimentar sensaciones desde el ámbito físico. ${ }^{3}$ ALONSO, E. El artículo 13 del Tratado de Funcionamiento de la Unión Europea: Los animales como seres «sensibles [sentientes]» a la luz de la jurisprudencia del Tribunal de Justicia de la Unión Europea, en FAVRE, D., GIMÉNEZ-CANDELA, T. (Eds.), Animales y Derecho (Valencia 2015) 32

${ }^{4}$ ALONSO, E. El artículo 13 del Tratado de Funcionamiento de la Unión Europea: Los animales como seres «sensibles [sentientes]» a la luz de la jurisprudencia del Tribunal de Justicia de la Unión Europea, en FAVRE, D., GIMÉNEZ-CANDELA, T. (Eds.), Animales y Derecho (Valencia 2015) 34

5 "The capacity to suffer or experience enjoyment or happiness".

${ }^{6}$ SINGER, P. All Animals are Equal, en Philosophic Exchange, 5 (1974) 7

7 "Self-aware"

8 "Distress"

${ }^{9}$ FRANCIONE, G. Animal Welfare and the Moral Value of nonhuman Animals, en Law, Culture and the Humanities (2010) 32

${ }^{10}$ ZUBIRI, X. La Inteligencia Sentiente (Madrid 1980) 10
} 
De acuerdo con lo expuesto anteriormente, considero que puede tomarse el concepto de sintiencia como la capacidad de sentir, tanto en el plano físico como psicológico (es decir, experimentar dolor y placer, como también felicidad y tristeza, entre otras sensaciones y emociones) y tener consciencia de dichas experiencias. Dado que en esta síntesis que se hace del concepto de sintiencia se tomará en cuenta la consciencia como un elemento esencial, considero relevante, en este punto, a modo de cierre de este aparte del texto, citar la Declaración de Cambridge sobre la Consciencia (2012), en la que se señala lo siguiente:

La ausencia de un neocórtex no parece prevenir que un organismo experimente estados afectivos. Evidencia convergente indica que los animales no humanos poseen los substratos neuroanatómicos, neuroquímicos y neurofisiológicos de estados conscientes, así como la capacidad de exhibir comportamientos deliberados. Por consiguiente, el peso de la evidencia indica que los seres humanos no son los únicos que poseen los sustratos neurológicos necesarios para generar conciencia. Animales no humanos, incluyendo todos los mamíferos y pájaros, y muchas otras criaturas, incluyendo los pulpos, también poseen estos sustratos neurológicos.

\subsection{Implicaciones del reconocimiento de la sintiencia de los animales no humanos}

Habiendo hecho las consideraciones previas acerca del significado y alcance del vocablo sintiencia, pasaremos ahora a estudiar las implicaciones que tiene, o debería tener, el reconocimiento del carácter de seres sintientes de los animales.

De acuerdo con el profesor David Favre, las consideraciones de índole moral y ética deben comenzar con todos los seres que tienen intereses propios, es decir, aquellos que son llevados a vivir una vida de conformidad con la codificación de su ADN y, en esa medida, deben considerarse las capacidades específicas de cada especie, como la consciencia y, en especial, la consciencia de sí mismos de los animales, para efectos de determinar qué derechos puede merecer un animal ${ }^{11}$.

En ese sentido, es importante destacar los elementos que pueden extraerse de la idea anteriormente parafraseada, que a mi juicio son tres: 1) Los seres con intereses propios merecen una consideración de índole moral o ética, 2) La consciencia es un elemento de gran relevancia a la hora de determinar los derechos que puede merecer un animal, y 3) Un aspecto que se hace evidente con la lectura del anterior, y es que los animales pueden merecer derechos. Así mismo es importante mencionar que el profesor Favre vincula la consciencia de los animales a los derechos que estos pueden merecer, y lo digo puesto que en las definiciones anteriores de sintiencia (en particular la dada por Gary Francione) se destaca la consciencia como uno de sus elementos.

Por otro lado, el Profesor Simone Pollo, trae a colación otro elemento sobre el que hasta ahora no se ha hablado en este texto: el bienestar. Pollo señala que, si se repara sobre el concepto de bienestar, se verá que su correcto uso siempre se refiere a seres sintientes, es decir "seres que pueden en algún modo 'experimentar' las condiciones a las cuales nos referimos con el término "bienestar""12 13

Así, explica Pollo, si un ser sintiente se encuentra en malas condiciones, tenemos razones para estar moralmente preocupados por dicho ser, y estas razones son diferentes de las que podríamos tener en casos en que un objeto no-sintiente estuviera en malas condiciones. Esto, en la medida en que -siguiendo el ejemplo planteado por Pollo- si una obra de arte fuese dañada por alguien, podríamos moralmente juzgar a quien dañó la obra por privar a las generaciones futuras de apreciarla, pero no habría lugar a la preocupación o simpatía en sí por el "sufrimiento" causado a la obra. La preocupación moral por la obra no está basada en una experiencia de aquella, sino en los intereses de otros, de los humanos que se ven afectados al ser privados de esta, por lo que no hay lugar a hablar de una ofensa o daño al bienestar de la obra. ${ }^{14}$

En ese orden de ideas, se observa que cuando hablamos de bienestar, nos referimos entonces a condiciones predicables de seres sintientes, que implican consideraciones de índole moral basadas en los intereses del animal en sí mismo. Por lo tanto, el bienestar es un concepto que implica la idea de que hay determinadas condiciones de la vida de un animal que son moralmente buenas o malas, porque hay un animal que las está experimentando. En otras palabras, al hablar de bienestar animal, aceptamos la idea de que los animales tienen experiencias subjetivas.

Sobre las ideas expresadas por el Profesor Simone Pollo, considero que los elementos de mayor relevancia para los efectos de este estudio son: 1) el concepto de bienestar se predica necesariamente de seres

\footnotetext{
${ }^{11}$ FAVRE, D. Animals as living property. En HÄNNI. J., KÜHNE. D. \& MICHEL. M., Animal Law- Tier und Recht (Zürich 2012 ) 418

12 "Beings that can somewhat 'experience' the conditions to which we refer with the term 'welfare"”

${ }^{13}$ POLLO, S. Animal Welfare, Animal Minds, Animal individuality (2007) 96

${ }^{14}$ POLLO, S. Animal Welfare, Animal Minds, Animal individuality (2007) 96
} 
sintientes, y 2) el concepto de bienestar implica, necesariamente, el reconocimiento de que los animales tienen experiencias subjetivas. En ese sentido, observamos, una vez más, cómo la consciencia de los animales está íntimamente ligada al concepto de sintiencia, en este caso mediante el reconocimiento de las experiencias subjetivas de aquellos. Finalmente, 3) los seres sintientes deben tener una consideración moral por y en sí mismos, y no, como ocurre con un objeto, según las consideraciones de terceros.

Por su parte, la Concejal de Bogotá Andrea Padilla, señala que varias teorías morales, entre ellas las de Peter Singer y Gary Francione, coinciden en que la capacidad de sintiencia debe ser la condición umbral -en palabras de Martha Nussbaum- "para incluir a los animales dotados de ella en el conjunto de seres cuyos intereses cuentan moralmente" 15 .

En el texto "Animales no humanos: nuevos sujetos de derecho en el constitucionalismo latinoamericano", Padilla estudia tres tendencias que se han dado dentro de la jurisprudencia latinoamericana reciente sobre protección animal, y señala que una de ellas es la que reconoce la protección animal por vía de la sintiencia, criterio determinante de consideración tanto moral como jurídica. Por ello, se entiende que el interés de los animales en no sufrir daños o en no ser maltratados, es un interés primario que le corresponde garantizar al Derecho, y que esta postura en particular se distancia de las otras que son expuestas en dicho estudio, por cuanto en esta "predomina el argumento de que los animales deben ser protegidos por sí mismos, en gracia de su animalidad sintiente". Es decir, que existe un imperativo moral de proteger a los animales por sí mismos, en consideración a su ser, y no debido a consideraciones externas, como ocurre en otras tendencias de protección de los animales, en las cuales no se los protege en consideración a ellos mismos, y a su capacidad de sentir y sufrir, sino con base en consideraciones antropocéntricas, como la dignidad humana, o de índole ambiental. ${ }^{16}$

Finalmente, señala Padilla que este imperativo moral se ve vulnerado cuando se inflige un daño a un ser o se lo expone a "experiencias aversivas como dolor, sufrimiento, miedo, angustia, frustración o la muerte, que vulneran su interés más fundamental en gozar de bienestar, a saber: un concepto amplio que incluye la ausencia de sufrimiento, la integridad física y la libertad corporal". ${ }^{17}$

Los aspectos fundamentales que, a mi juicio, se deben tener en cuenta respecto a las consideraciones hechas por Padilla son: 1) La sintiencia debe ser el umbral para la consideración moral de un ser, 2) el interés en no sufrir, en no ser dañado, es un interés primario que debe ser garantizado por el derecho, 3) los animales, como seres sintientes, merecen protección en sí mismos, en virtud de su ser y de los intereses que les son propios, 4) su interés más fundamental, es el de gozar de bienestar.

Luego de haber expuesto los planteamientos hechos por estos tres autores, considero que pueden extraerse cuatro ideas centrales sobre la sintiencia, a saber:

1. La sintiencia hace de los animales sujetos de consideración moral.

2. Los animales merecen una consideración moral en sí mismos, en virtud de su sintiencia, y no a raíz de consideraciones de terceros. El foco deben ser ellos y sus intereses.

3. Los animales, como seres sintientes con capacidades e intereses propios, pueden ser merecedores de derechos, los cuales que deben ser protegidos jurídicamente.

4. Las capacidades de los animales (dentro de las cuales se encuentra la consciencia, como elemento de la sintiencia) deben tenerse en cuenta para efectos de determinar los derechos de los que pueden ser titulares aquellos (David Favre habla de "merecer"), pero hay un interés fundamental que tienen los animales, que es el de gozar de bienestar. El cual implica, necesariamente, el respeto a la vida.

Tras realizar estas consideraciones sobre las implicaciones del reconocimiento del carácter de seres sintientes de los animales, analizaré las implicaciones de dicho reconocimiento desde el plano jurídico.

\footnotetext{
15 PADILLA, A. Animales no humanos: nuevos sujetos de derecho en el constitucionalismo latinoamericano. En ESTUPIÑAN. L, STORINI. C, MARTÍNEZ. R, \& DE CARVALHO DANTAS. F. A., La naturaleza como sujeto de derechos en el constitucionalismo democrático (Bogotá 2019) 392

${ }^{16}$ PADILLA, A. Animales no humanos: nuevos sujetos de derecho en el constitucionalismo latinoamericano. En ESTUPIÑAN. L, STORINI. C, MARTÍNEZ. R, \& DE CARVALHO DANTAS. F. A., La naturaleza como sujeto de derechos en el constitucionalismo democrático (Bogotá 2019) 403

${ }^{17}$ PADILLA, A. Animales no humanos: nuevos sujetos de derecho en el constitucionalismo latinoamericano. En ESTUPIÑAN. L, STORINI. C, MARTÍNEZ. R, \& DE CARVALHO DANTAS. F. A., La naturaleza como sujeto de derechos en el constitucionalismo democrático (Bogotá 2019) 412
} 


\section{Consideraciones jurídicas sobre el reconocimiento del estatus de seres sintientes de los animales no humanos y sus implicaciones.}

\subsection{Consideraciones preliminares sobre los conceptos de persona y sujeto de derecho.}

Antes de abordar el estudio de las implicaciones jurídicas del reconocimiento de los animales como seres sintientes, es preciso hacer unas consideraciones sobre los conceptos jurídicos de persona y sujeto de derecho.

En primer lugar, es importante señalar que estos conceptos se utilizan como sinónimos en muchas ocasiones, sin distinguir el uno del otro, y hay ordenamientos jurídicos en que ello se considera así, como es el caso de los ordenamientos de Argentina y Colombia ${ }^{18}$. No obstante, hay también consideraciones doctrinales según las cuales estos conceptos no significan lo mismo.

En segundo lugar, debe considerarse que la palabra persona -en sentido jurídico- no hace referencia únicamente a los seres humanos, sino que también incluye otros entes o seres que no tienen esa naturaleza. Así, suelen utilizarse las acepciones de persona natural o física para referirse a las personas que pertenecen a la especie humana, y persona jurídica, o moral, al hablar de entidades que adquieren su carácter de persona no por su naturaleza de ser humano sino por medio de una ficción que les confiere personalidad jurídica, como ocurre con las sociedades, por ejemplo. Al respecto, señala Giménez-Candela, que "persona es un término que se aplica también a realidades distintas del ser humano, se acepta, como ya se ha dicho, en todos los sistemas jurídicos occidentales. La distinción entre la llamada persona natural y la persona jurídica, obedece a la identificación entre persona e individuo humano" ${ }^{19}$. Al respecto, el código civil colombiano dispone lo siguiente en sus artículos 73 y 74 :

“Articulo 73. personas naturales o jurídicas. Las personas son naturales o jurídicas.

De la personalidad jurídica y de las reglas especiales relativas a ella se trata en el título final de este libro.

Articulo 74. personas naturales. Son personas todos los individuos de la especie humana, cualquiera que sea su edad, sexo, estirpe o condición."

En ese orden de ideas, en este texto se utilizarán los términos señalados anteriormente, adoptados en el Código Civil Colombiano, de modo que al referirme a personas estaré haciendo referencia a personas naturales y jurídicas, y no necesariamente a seres humanos.

En este mismo sentido se expresa Manuel Ossorio, quien señala que una persona es "un ser o entidad capaz de derechos y obligaciones, aunque no tenga existencia individual física, como las corporaciones, asociaciones, sociedades y fundaciones. (...) Capitant hace una definición análoga cuando dice que persona es el ente al que se reconoce capacidad para ser sujeto de derecho". ${ }^{20}$ Acá podemos ver una primera aproximación a la relación entre ambos conceptos, donde no se tratan como sinónimos, pero de la que se pueden extraer, en mi opinión, tres aspectos importantes: 1) que el concepto de sujeto de derecho es más amplio que el de persona, y este último se enmarca dentro de aquel; 2) se entiende por persona a un ente, por lo que este puede ser distinto de un ser humano; y 3) Puede haber sujetos de derecho que no sean personas, de modo que una persona siempre es sujeto de derecho, pero un sujeto de derecho puede no ser persona.

Ahora bien, entrando ya a las consideraciones sobre las diferencias y similitudes entre los conceptos de persona y sujeto de derecho, Nava Escudero indica que "es indispensable aclarar que la expresión sujeto de derecho es un concepto jurídico fundamental al igual que el de persona jurídica, y ningún jurista serio de nuestros días habría de sostener lo contrario. Sin embargo, existe cierta polémica entre algunos juristas respecto a que tal aseveración no deriva en aceptar de modo alguno que tales expresiones, si bien no son antagónicas, tampoco son intercambiables o sinónimas. En efecto, esta tradición de equiparación conceptual no siempre ha sido aceptada por la doctrina. Esta polémica ha tomado al menos dos rutas distintas de discusión. La primera de ellas rechaza la existencia real del sujeto de derecho como sustrato y, por lo tanto, niega tal sinonimia. [...] Esta postura conduce a reflexionar que sólo las personas tienen o pueden tener derechos, lo que de suyo excluye la posibilidad de que puedan existir titulares de derechos que no sean personas. Una segunda ruta de discusión se concentra en señalar que hay seres o entes que tienen o pueden tener derechos

\footnotetext{
${ }^{18}$ MOLANO. A \& MURCIA, D. Animales y naturaleza como nuevos sujetos de derecho: un estudio de las decisiones judiciales más relevantes en Colombia (Bogotá 2018) 92

${ }^{19}$ GIMÉNEZ-CANDELA, M. Persona y Animal: una aproximación sin prejuicios. dA.Derecho Animal (Forum of Animal Law Studies) 10/1 (2019) 11. https://doi.org/10.5565/rev/da.417

${ }^{20}$ OSSORIO, M. Diccionario de ciencias jurídicas, políticas y sociales (Buenos Aires 2015) 715
} 
sin ser personas jurídicas. El punto de partida es que tener derechos no es exclusivo de persona" ${ }^{21}$. De lo dicho por Nava Escudero, observamos que hay una tendencia doctrinal a la no equiparación de los dos conceptos, según la que, aunque estos no sean contrarios, tampoco pueden considerarse como sinónimos. Sobre las dos opciones que señala el autor, estoy de acuerdo con la segunda de ellas, según la cual es posible considerar que hay seres o entes que pueden ser titulares de derechos sin ser reconocidos como personas, lo cual ha sido declarado jurisprudencialmente en diversos países.

De otro lado, Galiano Maritán indica que "cuando la persona natural, con personalidad jurídica reconocida por el Estado, actúa en el marco de una relación jurídica determinada, se convierte entonces en sujeto de derecho. [...] Por tanto, queda claro que persona es el ente sustantivo del ordenamiento jurídico al que se le reconoce capacidad para ser titular de derechos y obligaciones, y sujeto de derecho es esa persona, pero sólo actuando en el marco de una relación jurídica bien como titular de un derecho o sujeto activo, o como titular de un deber u obligación o sujeto pasivo, y sólo desenvolviéndose en ese contexto se considerará como tal" 22 .

Nuevamente, se determina a la persona como un ente a quien se le reconoce la capacidad para ser titular de derechos y obligaciones, tal como señalaba Ossorio. Sin embargo, sobre la idea citada anteriormente, considero que es importante resaltar que se entiende que la calidad de sujeto de derecho se obtiene cuando se actúa dentro de una relación jurídica, bien como sujeto activo o como sujeto pasivo, por lo que, creo, esta definición deja las puertas abiertas a que otros entes, no considerados como personas, puedan también ser sujetos de derecho, incluso sin que se les reconozca la titularidad de derechos y de obligaciones, en la medida en que, como ocurre en algunos ordenamientos jurídicos con los animales, estos pueden ser objeto de un deber de protección por parte de los humanos sobre aquellos, y en esa medida podrían ser sujetos pasivos de una relación jurídica y, entonces, sujetos de derecho.

La discusión sobre el alcance y las definiciones de los conceptos de persona y sujeto de derecho es muy amplia y puede ser objeto de estudios mucho más profundos, teniendo en cuenta la relevancia que estos conceptos tienen en el mundo jurídico. Sin embargo, no es el objeto del presente estudio y, por lo tanto, considero que basta con lo señalado y con las siguientes conclusiones:

1. Aunque en muchas ocasiones y dentro de algunos ordenamientos jurídicos los conceptos de persona y sujeto de derecho se traten como sinónimos, lo cierto es que cabe al menos la duda de si en realidad lo son, y doctrinalmente hay tendencias con argumentos suficientes para considerar que no deberían tratarse como tal.

2. Por persona se entienden seres o entidades capaces de ser titulares de derechos y obligaciones.

3. De acuerdo con la conclusión anterior, en sentido jurídico, el concepto de persona no equivale al de ser humano, en tanto el derecho permite que haya otros entes con la capacidad de ser titulares de derechos y obligaciones, como las personas jurídicas, de modo que todos los seres humanos son personas, pero no todas las personas son seres humanos.

4. El concepto de sujeto de derecho es más amplio que el de persona, por lo que es válido sostener que puede haber sujetos de derecho que no sean personas (ni naturales, ni jurídicas). En ese sentido, toda persona es sujeto de derecho, pero no todo sujeto de derecho es persona.

\subsection{Consideraciones jurídicas sobre el reconocimiento de la sintiencia.}

La legislación colombiana reconoció el estatus de seres sintientes de los animales en el artículo $1^{\circ}$ de la Ley 1774 de 2016 (aunque dicha condición se reconoce por vía jurisprudencial desde el año 2010 con la sentencia C-666 de la Corte Constitucional), en el cual, además, se indica expresamente que los animales "no son cosas". Esto abre la puerta a una diversidad de consideraciones que pueden hacerse sobre el estatus que tienen, entonces, los animales, en la medida en que, al no ser cosas, no pueden considerarse meramente como objetos, pero entonces ¿cómo deben considerarse jurídicamente? ¿Tienen derechos?

Antes de proceder con las consideraciones pertinentes frente a los interrogantes planteados anteriormente, cabe resaltar que, aunque en Colombia se indique expresamente que los animales no son cosas, se les sigue ubicando dentro del Código Civil como tal, en la medida que el artículo 654 de este señala que "Las cosas corporales se dividen en muebles e inmuebles" y, a continuación, el artículo 655 (que fue modificado por la citada Ley 1774 de 2016) indica que "Muebles son las que pueden transportarse de un lugar

\footnotetext{
21 NAVA ESCUDERO, C. Los Animales como Sujetos de Derecho. dA. Derecho Animal (Forum of Animal Law Studies) 10/3 (2019) 57. https://doi.org/10.5565/rev/da.444

${ }^{22}$ GALIANO MARITAN, G. Reflexiones conceptuales sobre las categorías: Persona, Personalidad, Capacidad y Sujeto de Derecho. Derecho y Cambio Social (2013) 11
} 
a otro, sea moviéndose ellas a sí mismas como los animales (que por eso se llaman semovientes), sea que sólo se muevan por una fuerza externa, como las cosas inanimadas" (Subrayado fuera del texto). Vale la pena resaltar que en el parágrafo de este artículo se reconoce, nuevamente, la calidad de seres sintientes de los animales.

Ahora sí, procederé con las consideraciones del caso frente a la categorización jurídica de los animales. Como señala la profesora Giménez-Candela ${ }^{23}$, las últimas décadas han presenciado un auge en las reflexiones que se dan en torno a los animales en la esfera jurídica. Así, la concepción del animal como una cosa ha sido objeto de diversas consideraciones y, como resultado de ello, de modificaciones en el ámbito legislativo. Esto ocurrió, en primer lugar, en Austria, donde se introdujo una modificación en el Tratado de Propiedad del Código Civil de dicho país, mediante la cual se determinó que los animales no son cosas y se rigen por leyes especiales, modificación que repercutiría posteriormente en Alemania y, más tarde, en Suiza, países cuyos códigos civiles fueron reformados en el mismo sentido que el austríaco. Estos cambios son muestra del rompimiento con un concepto o categoría clásica, a saber, la de los animales como cosas en propiedad.

Giménez-Candela señala también que, a partir de los cambios expuestos anteriormente, otros países han adoptado la fórmula de señalar a los animales como "no cosas", y se ha visto una tendencia dentro de los códigos civiles europeos a buscar una definición jurídica de los animales que se adapte a la condición que tienen estos de seres sintientes, condición reconocida por la ciencia desde hace bastante tiempo. Este rompimiento con el estatus jurídico de los animales como cosas, es un primer paso de gran relevancia, por cuanto, como señala Lachance, los animales, en general, se encuentran atrapados en las estructuras rígidas del sistema del Derecho Civil, que no les admite como personas en sentido jurídico y son, por lo tanto, un bien del que se puede abusar. ${ }^{24}$

El derecho es una ciencia que debe ajustarse a la realidad, que debe moverse en el sentido en que lo hacen los movimientos sociales, y debe adaptarse a las nuevas formas de pensar y a los avances de otras ciencias. La ley debe ajustarse a los aspectos mencionados anteriormente, para tener vigencia (no en el sentido formal), y amoldarse a la realidad. En este momento el derecho es un elemento central para la opresión de los animales, por cuanto es el sistema legal el que autoriza a los humanos a lastimarlos y explotarlos, motivo por el cual es esencial que haya una reforma en el ámbito jurídico para terminar con su opresión. ${ }^{25}$ En ese orden de ideas, es imperioso que el derecho se adapte a lo que las ciencias naturales ya han demostrado, a un planteamiento que no se discute, que es el de la sintiencia de los animales, planteamiento que además ha ido permeando también en la forma de pensar de los seres humanos, y que crece entre estos día a día. Actualmente, es muy difícil encontrar a alguien que, en realidad, considere que los animales son cosas y que no merecen consideración moral alguna. Por supuesto, esto tendrá excepciones y matices, puesto que los seres humanos parecemos dar mayor importancia a unos animales (a sus vidas) que a otros, pero es una tendencia creciente en la sociedad. Como señala Pezzeta, citando a Sunstein, "casi todos acordamos en que los animales no humanos tienen derechos, pero esta expresión requiere de aclaración. Es entonces cuando el acuerdo desaparece: en la búsqueda de la especificación sobre qué significa decir que un ANH [Animal No Humano] tiene derechos, qué derechos y de qué tipo. Sin embargo, es importante partir de este primer nivel muy general y rudimentario de coincidencia sobre los derechos de los ANH para poder explorar una fundamentación de los mismos y determinar cuáles serían -así como eliminar distinciones arbitrarias entre especies de animales no humanos-“. ${ }^{26}$

Explica también la profesora Giménez-Candela que este cambio (considerar a los animales como nocosas) puede ser criticado en la medida en que tampoco determina qué son los animales en sí, puesto que se trata de una categoría negativa, es decir, no se les da un estatuto jurídico nuevo, ni se mejora su condición jurídica, y se les "define" a partir de lo que no son, aunque, sin duda, este cambio en la consideración de los animales abre la puerta a que su condición jurídica se rija por sus propias leyes.

Ahora, si bien es claro que estamos ante un avance importante en el ámbito jurídico frente a la consideración de los animales, concuerdo con lo dicho por la profesora Giménez-Candela, en la medida que no basta con la creación de una categoría negativa (no-cosas) para determinar qué son los animales jurídicamente y, por tanto, debe hacerse un esfuerzo por definirles por lo que son, y no limitarse a señalar lo que no son. Esto abre la posibilidad de una consideración adicional, a saber: ¿es necesaria la creación de una categoría jurídica propia, nueva, específicamente para los animales (lo que implicaría la delimitación y

\footnotetext{
${ }^{23}$ GIMÉNEZ-CANDELA, M. Transición Animal en España (Valencia 2020) 159

${ }^{24}$ LACHANCE, M. Animals as Sentient Beings: Are we Concerned by Animal Suffering in Canada? En FAVRE. D. \& GIMÉNEZCANDELA. T., Animales y Derecho (Valencia 2015) 259

${ }^{25}$ KYMLICKA, W. Social Membership: Animal Law Beyond the Property/Personhood Impasse, en Dalhousie Law Journal 40 (2017) 124

${ }^{26}$ PEZZETA, S. Una teoría del derecho para los animales no humanos. Aportes para la perspectiva interna del Derecho, en Revista Bioética y Derecho 44 (2018) 169
} 
definición de dicha categoría) o pueden estos ser enmarcados dentro de una categoría jurídica ya existente?

A pesar del avance que ha habido en las relaciones entre los animales y el Derecho, existe aún un rechazo a repensar la aplicación del término "persona" y de su ampliación de modo que se incluya, dentro de ella, a los animales, y se mantiene la tendencia o mentalidad a definirles como cosas. Al respecto, creo que es pertinente recordar un caso que señala la profesora Giménez-Candela, ocurrido en la India, y sobre el que expresa que "contra toda lógica asentada, así se ha hecho en la legislación de la India, donde se califica a los delfines como "personas no-humanas". Puede cuestionarse si el término es acertado o existe otro mejor, pero, para quien se extrañe de esta reflexión, quiero recordar que el término "persona", se aplica, desde hace muchos siglos, a entes que nada tienen que ver con un ser humano, y sí con patrimonios, actividades, funciones. Es decir, "personas jurídicas", no humanas...". 27

Dentro de las consideraciones que hace la profesora Giménez-Candela, señala los siguientes objetivos que se deberían alcanzar en el marco del "binomio Animales y Derecho": 1) Lograr una definición jurídica del animal que se aparte de la consideración de estos como cosas o productos, 2) considerar el bienestar animal como un compromiso dentro del desarrollo sostenible, 3) la protección normativa de los animales frente al sufrimiento innecesario, 4) la promoción de estudios sectoriales destinados a distintos ámbitos de interés (jurídico, social, económico, veterinario) y 5) lograr aunar esfuerzos por parte de agentes potencialmente implicados en el bienestar animal (administraciones públicas, sociedades protectoras, agentes económicos encargados del transporte, alimentación sacrificio y experimentación técnica).

Para efectos del presente estudio, considero especialmente importantes los dos primeros objetivos, es decir, el lograr una definición jurídica de los animales alejada de la consideración de aquellos como cosas, y considerar el bienestar animal como un compromiso dentro del desarrollo sostenible. Sobre el primero, hablaré a continuación, mientras que sobre el bienestar animal hablaré más adelante en el aparte 5.4. Trabajo Animal, aunque desde una perspectiva distinta a la planteada por la profesora Giménez-Candela.

Abordaré a continuación el primero de los objetivos planteados por la profesora Giménez-Candela, a saber, el de lograr una definición jurídica de los animales que se aparte del concepto clásico de los animales como cosas y, en ese orden de ideas, retomo la pregunta que planteé anteriormente: a partir del reconocimiento de los animales como seres sintientes desde el punto de vista biológico y jurídico ¿es necesaria la creación de una categoría jurídica propia para los animales o pueden estos ser enmarcados dentro de una categoría existente?

Con el reconocimiento de los animales como seres sintientes se ha levantado la discusión sobre si ello implica el reconocimiento de los animales como personas -en el sentido jurídico de la palabra, por supuestoo como sujetos de derecho o, tal vez, de alguna otra forma. Para ello retomaré y ampliaré el tema de los conceptos de persona y de sujeto de derecho, así como sus definiciones.

Como se mencionó anteriormente, estos dos conceptos, en diversos estudios, se tratan como sinónimos, usándolos para referirse a quien puede ser titular de derechos y obligaciones en el ámbito jurídico. Sin embargo, existen también posiciones dentro de las que se sostiene -en palabras de César Nava Escudero- que "tales expresiones, si bien no son antagónicas, tampoco son intercambiables o sinónimas" ${ }^{2}$. Siguiendo con lo señalado por Nava Escudero, uno de los caminos que ha tomado esta discusión sobre las diferencias entre el concepto de persona ${ }^{29} \mathrm{y}$ de sujeto de derecho, es que la posibilidad de tener derechos no es algo exclusivo de una persona y, en ese sentido, se abre la posibilidad para la existencia de otras expresiones o categorías jurídicas que designen a seres o entes que puedan ser titulares de derechos, sin tener la consideración de persona. Como ejemplos de esto señala el autor, en el ámbito del derecho internacional, la humanidad y los movimientos de liberación nacional; en el ámbito del derecho ambiental, la madre tierra y la naturaleza, y, por otro lado, el nasciturus (un ser humano concebido, pero que aún no ha nacido) cuyo reconocimiento de personalidad o estatus de persona está sujeta al cumplimiento de una condición, cual es, su nacimiento. Sobre estos últimos, cabe señalar que, aunque no se los considere como personas, sí son titulares de protección a la vida, como se observa expresamente en los artículos 90 y 91 del Código Civil Colombiano.

En ese orden de ideas, vemos que la titularidad de derechos no viene siempre aparejada con la consideración jurídica del titular de aquellos como persona. Señala Nava Escudero que es posible identificar

\footnotetext{
${ }^{27}$ GIMÉNEZ-CANDELA, M. Transición Animal en España (Valencia 2020) 165

${ }^{28}$ NAVA ESCUDERO, C. Los Animales como Sujetos de Derecho. dA. Derecho Animal (Forum of Animal Law Studies) 10/3 (2019) 56. https://doi.org/10.5565/rev/da.444

${ }^{29}$ Hablo de persona aunque el autor habla de persona jurídica en la medida en que en la persona jurídica en la legislación colombiana hace referencia a lo que en México se conoce como persona moral, es decir aquellos entes que adquieren su personalidad jurídica a partir de una ficción jurídica, y no por su condición de ser humano, como ocurre con las personas naturales o físicas, y en este aparte se hace referencia al concepto de persona que abarca tanto a seres humanos (personas naturales o físicas) como a aquellos entes que son personas sin tener la calidad de ser humano.
} 
un rechazo doctrinal a la posibilidad de considerar a los animales como personas, el cual se basa, en buena medida, en dos motivos: el primero, la cercanía que en el mundo jurídico han tenido los conceptos de humano y persona, y el segundo, "que sólo hay dos tipos de persona jurídica, la física y la moral". ${ }^{30}$

En este punto, es importante hacer una precisión, y es que la terminología usada por Nava Escudero corresponde al ordenamiento jurídico mexicano, y difiere de la utilizada en el colombiano. De acuerdo con la definición que él da, y conforme a los artículos 22 a 28 del Código Civil Federal de México, dentro de la categoría de persona (esta es la categoría general) están las personas físicas y las morales, y se entiende que "la persona física es un ser humano, la persona moral o jurídica, en cambio, es un ente de creación artificial, con capacidad para tener un patrimonio, adquirir derechos y contraer obligaciones". ${ }^{31}$ Por otra parte, en el ordenamiento jurídico colombiano no se usan estos mismos términos, pues en este, la categoría general es la de persona, y dentro de esta se enmarcan las personas naturales y las jurídicas ${ }^{32}$, que corresponderían a las físicas y morales, respectivamente.

La precisión es útil para efectos de ubicarse según la terminología que se usa en cada país, sin embargo, la realidad es la misma, tanto en una como en otra legislación, solo hay dos tipos de personas (en este texto adopto la terminología de la ley colombiana): las naturales, que son "todos los individuos de la especie humana, cualquiera que sea su edad, sexo, estirpe o condición" ${ }^{33}$, y las jurídicas, "Se llama persona jurídica, una persona ficticia, capaz de ejercer derechos y contraer obligaciones civiles" ${ }^{34}$, y por tanto la dificultad que se presenta sigue allí: dentro de ninguna de estas categorías pueden (aparentemente) ser incluidos los animales.

De igual forma, es importante tocar el tema de la capacidad de los animales en el sentido jurídico de la palabra. La capacidad es un atributo de la personalidad, y puede ser definida como "la aptitud de tener o ejercitar derechos y facultades o ser sujeto de obligaciones y responsabilidades jurídicas" 35 . El artículo 1502 del Código Civil colombiano señala que "La capacidad legal de una persona consiste en poderse obligar por sí misma, sin el ministerio o la autorización de otra". Si entendemos que las personas (tanto naturales como jurídicas) tienen como un atributo propio la capacidad, y esta es precisamente la facultad de poder obligarse por sí mismas, de poder tener obligaciones y responsabilidades jurídicas, es claro que no podría incluirse, entonces, a los animales dentro de esta categoría.

En ese orden de ideas considero que debe abandonarse la idea de considerar a los animales como personas, y puede -en principio- ser más apto el concepto se sujeto de derecho para incluir a los animales, en la medida en que no se presentan las dificultades doctrinales que se han señalado anteriormente, y que la noción de sujeto de derecho es más amplia. Ferrajoli señala que “'sujeto' tiene ciertamente una extensión mayor que la de 'ser humano', esto es, que la de la clase formada por los hombres y las mujeres, y mayor también que la de 'persona', que como veremos en el capítulo VII corresponde a un estatus jurídico específico asociado a algunos sujetos por el derecho positivo. Por ejemplo, en los sistemas jurídicos existen sujetos e incluso personas que no son seres humanos, como los entes a los que se reconoce como personas jurídicas, y por otro lado sujetos que no son personas" 36 .

Por tanto, es válido señalar que toda persona se considera, necesariamente, sujeto de derecho, pero este concepto no se encuentra limitado a las personas, sino que es más amplio, y este sería el panorama dentro del cual podría considerarse a los animales como sujetos de derecho, sujetos que pueden ser titulares de derechos, o al menos sujetos sobre los cuales recae un deber de protección por parte de los humanos en el marco de una relación jurídica, pero que carecen de capacidad jurídica, de modo que carecen de capacidad para contraer o tener obligaciones. $\mathrm{Al}$ respecto, Nava Escudero dice que:

La expresión subjectum iuris o sujeto de derecho aparece en el Derecho como supraconcepto, o si se quiere, como concepto primordial y, por lo tanto, es prescindible acudir a otras nociones (como la de persona) para argumentar que los animales tienen o pueden tener derechos. En otras palabras, la subjetividad jurídica permite predicar derechos a seres o entes que no se identifiquen con persona o ser humano. $[\ldots]$

Si bien se delibera que tanto sujeto de derecho como persona jurídica son conceptos de amplio

\footnotetext{
${ }^{30}$ NAVA ESCUDERO, C. Los Animales como Sujetos de Derecho. dA. Derecho Animal (Forum of Animal Law Studies) 10/3 (2019) 58. https://doi.org/10.5565/rev/da.444

${ }^{31}$ FERNÁNDEZ RUIZ, J. Personas Jurídicas de Derecho Público en México, en Boletín Mexicano de Derecho Comparado 89 (1997). 467

${ }^{32}$ Código Civil colombiano, artículo 73

${ }^{33}$ Código Civil colombiano, artículo 74

${ }^{34}$ Código Civil colombiano, artículo 633

${ }^{35}$ NAVA ESCUDERO, C. Los Animales como Sujetos de Derecho. dA. Derecho Animal (Forum of Animal Law Studies) 10/3 (2019) 60. https://doi.org/10.5565/rev/da.444

${ }^{36}$ FERRAJOLI, L. Principia iuris - Teoría del derecho y de la democracia. (Madrid 2013) 173
} 
contenido que permitirían incluir a seres o entes de los que se predican derechos como seria el caso de los animales, el primero no ha estado acompañado (a diferencia del segundo) de las resistencias doctrinales que al efecto se han enarbolado para oponerse a tal propuesta. Es verdad que desde sus orígenes y durante muchos años, el concepto de persona jurídica ha gozado de amplitud de contenido, situación que ha contribuido a argumentar que tal expresión pueda utilizarse sin mayor problema para designar a los animales como sustentantes, portadores o titulares de derechos. Sin embargo, y como ya se ha advertido, la extensión del concepto de persona hacia los animales y su eventual posición en el Derecho (ya sea en la persona física o moral, en una categoría intermedia o cuasi-categoría, o incluso en un tercer tipo de persona), pueden conducir a absurdos jurídicos o indeterminaciones conceptuales que en poco o en nada ayudarían a precisar el estatus jurídico de los animales como sujetos de derechos ${ }^{37}$.

Para responder el interrogante planteado en este aparte del estudio, considero que, si debiera incluirse a los animales dentro de una categoría jurídica existente, la más apropiada sería la de sujetos de derecho, en la medida en que la categoría de persona acarrea muchas (más) dificultades y parece incompatible con la naturaleza de los animales, en cuanto implica la capacidad de ser titular de derechos y obligaciones. Aun cuando se llegare a reconocer a los animales como titulares de derechos, creo que no es viable proponer que se les considere como capaces de contraer obligaciones. Adicionalmente, y de acuerdo con las conclusiones hechas previamente en el aparte "Consideraciones preliminares sobre los conceptos de persona y sujeto de derecho", el concepto de sujeto de derecho es más amplio que el de persona, y da lugar a la existencia de sujetos de derecho que no sean personas, lo que permitiría la inclusión de los animales en esta categoría.

Finalmente, puede señalarse un argumento adicional a favor de esta propuesta, y es que hay ordenamientos jurídicos en que no se reconoce a los animales como titulares de derechos, sino como objetos de una protección especial, supuesto frente al cual cabe mencionar de nuevo la posibilidad de que la calidad de sujeto de derecho se obtenga por ser parte de una relación jurídica, de forma que aun en los casos en que no se reconozca a los animales como titulares de derechos, pero sí de un deber de protección, estos estarían dentro del marco de una relación jurídica y, en esa medida, podrían ser sujetos de derecho.

A pesar de lo anterior, siguen existiendo dificultades en cuanto a la inclusión de los animales como sujetos de derecho, particularmente si se tiene en cuenta que en muchos casos se consideran sinónimos los conceptos de persona y sujeto de derecho, de modo que en los ordenamientos en que ello es así, no podría entenderse a los animales como sujeto de derecho, al menos en principio, por cuanto ello implicaría reconocer que pueden ser titulares de derechos y obligaciones, siendo que, en mi opinión, no es posible entender que los animales puedan tener capacidad para ser titulares de obligaciones, aunque sí de derechos.

No obstante lo dicho anteriormente, considero que el ideal es que se defina la categoría de seres sintientes como una categoría jurídica en propiedad, dentro de la cual se determine específicamente a los animales como entidad jurídica, como seres que pueden ser titulares de derechos (en un mundo ideal, fundamentales e inviolables), como sujetos individualmente considerados, pero sin deberes y sin capacidad de ser titulares de obligaciones y, por otro lado, titulares de deberes generales de protección por parte de los seres humanos, no ya solo individualmente considerados, sino colectivamente como animales no humanos.

Es relevante señalar -de acuerdo con Giménez-Candela- que la idea de extender a los animales la personalidad jurídica ha aparecido como una consecuencia de la afirmación de su sintiencia, y en los últimos años se ha empezado a utilizar y a justificar la aplicación del término persona a los animales, como en el caso de Alemania, donde, señala, "una propuesta novedosa como esta, no ha producido reacciones en contra procedentes de la dogmática jurídica, en parte porque la introducción de la categoría de 'persona animal', no pretende alterar la estructura del BGB ["Bürgerliches Gesetzbuch" o Código Civil de Alemania] establecida, como es habitual, sobre la base de la distinción entre persona natural y persona jurídica, sino conservar dicha distinción y añadir una nueva categoría de persona animal sin confrontación o menoscabo de las prerrogativas de los seres humanos" ${ }^{\prime 38}$. En ese sentido, aunque no creo que deba utilizarse la categoría de persona para incluir a los animales, concuerdo en la importancia de definirlos o incluirlos dentro de una clasificación que no tenga o pueda conllevar una confrontación o menoscabo de las prerrogativas propias de los seres humanos (esto teniendo en cuenta, como ya se ha indicado, que se suele asemejar el concepto de persona al de ser humano), simplemente para efectos de facilitar el reconocimiento de la misma.

\footnotetext{
${ }^{37}$ NAVA ESCUDERO, C. Los Animales como Sujetos de Derecho. dA. Derecho Animal (Forum of Animal Law Studies) 10/3 (2019) 62. https://doi.org/10.5565/rev/da.444

${ }^{38}$ GIMÉNEZ-CANDELA, M. Persona y Animal: una aproximación sin prejuicios. dA.Derecho Animal (Forum of Animal Law Studies) 10/1 (2019) 12. https://doi.org/10.5565/rev/da.417
} 
Es importante resaltar que, en mi opinión, esta categoría jurídica de seres sintientes debería conllevar el reconocimiento como titulares de derechos propiamente hablando, y no simplemente como sujetos frente a los cuales hay un deber de protección por parte de los humanos (también, sí, pero sin limitarse a ello). Frente a la cuestión de los derechos de los animales, señala Sunstein que, si se entiende por derechos la protección legal contra un daño, entonces muchos animales ya tienen derechos, y en ese sentido la idea de derechos no es controversial ${ }^{39}$. Por otro lado, si entendemos que los derechos significan una legitimación moral de dicha protección, observamos que hay un consenso general sobre que los animales tienen derechos de alguna clase. En efecto, como ya he mencionado, la idea general que parece encontrarse entre los seres humanos es que los animales merecen "algún" tipo de derechos, y ya existen normas que los protegen contra ciertas conductas, protección legal que, considero, implica un reconocimiento de un derecho, aun cuando sea de forma subyacente, porque la protección tiene como fundamento, precisamente, ese derecho, aunque este no esté expresamente mencionado en una determinada norma.

\subsection{La naturaleza y los animales como sujetos de derecho. Aproximación jurisprudencial en Latinoamérica, y el reciente caso del elefante Kaavan.}

\subsubsection{El caso del Río Vilcabamba y el caso de los ríos Yamuna y Ganges.}

Molano y Murcia exponen, en el texto Animales y naturaleza como nuevos sujetos de derecho: un estudio de las decisiones judiciales más relevantes en Colombia, el caso del 2011 del Río Vilcabamba, en Ecuador, en el que en un período de lluvias la creciente de este arrastró toneladas de desechos de construcción de una carretera que no tenía el correspondiente estudio de impacto ambiental, afectando terreno fértil de propiedad de unos ciudadanos, quienes interpusieron una acción de protección contra el gobierno provincial. De este caso, considero como elemento relevante (para efectos de este texto) el reconocimiento como sujeto de derecho de la naturaleza por parte de la Constitución de Ecuador, y el reconocimiento por parte de la Corte que conoció del caso de "el derecho que la Naturaleza tiene de que se le respete integralmente su existencia y el mantenimiento y regeneración de sus ciclos vitales, estructura, funciones y procesos evolutivos" 40 Así mismo, las autoras señalan lo ocurrido en el caso de los Ríos Yamuna y Ganges, en 2017, cuando la Corte de Uttarakhand los declaró como "entidades vivientes que tienen el estatus de persona con todos los derechos, obligaciones y responsabilidades correspondientes de una persona viva con el fin de ser preservados". ${ }^{41}$

En ese sentido, encontramos precedentes en que se reconoce el estatus de sujeto de derecho (Caso Río Vilcabamba) o de persona (Caso ríos Yamuna y Ganges) a entidades que no pueden ser enmarcadas dentro de las categorías clásicas de persona, a saber, una persona natural o una persona jurídica y, sin embargo, se hacen dichos reconocimientos para efectos de -valga la redundancia- reconocer y proteger los derechos de estas entidades.

\subsubsection{Caso de la orangutana Sandra - Argentina}

Un caso semejante sucedió en Argentina, en el 2015, cuando la Cámara Federal de Casación Penal, Sala II, resolvió una acción de amparo interpuesta contra el Gobierno de la Ciudad de Buenos Aires y el Jardín Zoológico de dicha ciudad. En esta Sentencia, la sala abordó el problema del estatus jurídico de Sandra, una orangutana del zoológico, revisando si se le debería considerar como un sujeto de derecho o como un objeto ${ }^{42}$. Al respecto, la Sala concluyó que "Corresponde reconocer a la orangutana como un sujeto de derecho, conforme lo dispuesto por la Ley 14.346 y el CCivCom., en cuanto al ejercicio no abusivo de los derechos por parte de sus responsables, toda vez que es una persona no humana, y por ende, sujeto de derechos y consecuentes obligaciones hacia ella por parte de las personas humanas". ${ }^{43}$

Acá cabe resaltar que la sala clasifica a la orangutana como sujeto de derecho y al mismo tiempo como una "persona no humana", advirtiendo que esta clasificación no la iguala a la persona humana y no modifica las categorías existentes en el código civil. Sin embargo, de acuerdo con algunos planteamientos hechos anteriormente, considero que puede ser conflictivo el reconocimiento de los animales no-humanos dentro de la categoría de persona, en la medida en que carecen de capacidad en el sentido jurídico de la palabra.

\footnotetext{
${ }^{39}$ SUNSTEIN, C. R. The Rights of Animals, en The University of Chicago Law Review 70 (2003) 389

${ }^{40}$ Corte Provincial de Loja, Sala Penal, 11121-2011-0010, 2011

${ }^{41}$ MOLANO. A \& MURCIA, D. Animales y naturaleza como nuevos sujetos de derecho: un estudio de las decisiones judiciales más relevantes en Colombia (Bogotá 2018) 88

${ }^{42}$ Cámara Federal de Casación Penal, Sala II, Causa CCC68831/2014/CFCI

${ }^{43}$ Cámara Federal de Casación Penal, Sala II, CCC68831/2014/CFCI, 2015, Considerando II, párr. 2
} 
Aun así, hay dos puntos sobre los que se sustenta la decisión y que resultan, a mi parecer, de gran importancia, a saber: 1) el reconocimiento de la dignidad y la vida como principios aplicables a los animales como seres sintientes, y 2) que las categorías jurídicas son socialmente construidas y, por lo tanto, dinámicas, y en ese sentido la asignación de derechos corresponde a construcciones que dependen de las condiciones históricas y sociales ${ }^{44}$.

Finalmente, esta sentencia, con base en los argumentos señalados anteriormente y en otros más que no corresponde señalar expresamente por no relacionarse directamente con el punto a tratar acá, resuelve favorablemente la acción de amparo, y declara a la orangutana Sandra como un sujeto de derechos, por lo que ordena que "El Gobierno de la Ciudad Autónoma de Buenos Aires deberá garantizar a Sandra las condiciones adecuadas del hábitat y las actividades necesarias para preservar sus habilidades cognitivas" 45 .

\subsubsection{Caso de la chimpancé Cecilia - Argentina}

También en Argentina, esta vez en Mendoza, el tercer Juzgado de Garantías del Poder Judicial de la ciudad resolvió un caso semejante, el de la chimpancé Cecilia, que se trataba también de una acción de habeas corpus que fue interpuesta en favor de Cecilia. Al resolver esta acción, el juzgado abordó el tema planteando la cuestión sobre si los grandes simios, como orangutanes, bonobos, gorilas y chimpancés, podían considerarse sujetos de derechos no humanos, cuestión que fue resuelta de forma afirmativa.

Así, señala la sentencia que "Resulta innegable que los grandes simios, entre los que se encuentra el chimpancé, son seres sintientes por ello son sujetos de derechos no humanos. Tal categorización en nada desnaturaliza el concepto esgrimido por la doctrina. El chimpancé no es una cosa, no es un objeto del cual se puede disponer como se dispone de un automóvil o un inmueble. Los grandes simios son sujetos de derecho con capacidad de derecho e incapaces de hecho, en tanto, se encuentra ampliamente corroborado según la prueba producida en el presente caso, que los chimpancés alcanzan la capacidad intelectiva de un niño de 4 años. Los grandes simios son sujetos de derechos y son titulares de aquellos que son inherentes a la calidad de ser sintiente" 46 .

Al respecto, Molano y Murcia señalan que "En esta sentencia se considera que la calificación que el Código Civil y Comercial les da a los animales como cosa es contraria a la de ser sintiente. Así, define a los animales como seres sintientes y de esta calidad colige que los primates son sujetos de derechos fundamentales con dos precisiones: (i) son incapaces (absolutos) de hecho y (ii) tienen solo los derechos inherentes a la calidad de ser sintiente (Tercer Juzgado de Garantías del Poder Judicial de Mendoza, P-72.254/15, 2016, p. 33). (...) En esta sentencia se afirma que la categoría de sujeto de derecho también les es aplicable a los primates, por vía de las similitudes entre el humano y el simio en cuanto 'también [son] de carne hueso, nacen, sufren, beben, juegan, duermen, tienen capacidad de abstracción, quieren, son gregarios, etc." "47.

Sobre el aparte citado anteriormente, vale la pena hacer una serie de consideraciones: en primer lugar, es importante resaltar cómo el Juzgado conecta la calidad de seres sintientes de los animales con la de sujetos de derecho, de modo que la primera acarrea como consecuencia la segunda; en segundo lugar, el juzgado considera a los animales como sujetos de derecho, sí, pero como incapaces de hecho, lo que en la legislación colombiana equivaldría a incapaces absolutos (como señalan las autoras), es decir, que no pueden obligarse, ${ }^{48}$ lo que es consecuente con la posición señalada anteriormente en la que indico que no se debe categorizar a los animales como personas en la medida en que carecen de capacidad jurídica. Sin embargo, es preciso resaltar que, de conformidad con lo dicho por Molano y Murcia, en el sistema jurídico argentino la calidad de sujeto de derecho corresponde con la de persona, al igual que en el ordenamiento jurídico colombiano ${ }^{49}$.

El tercer punto que considero relevante resaltar, es que la sentencia estipula que los animales, "tienen solo los derechos inherentes a la calidad de ser sintiente", pero ¿qué derechos son inherentes a la calidad de ser sintiente? Lo lógico sería pensar que cualquier forma de daño físico o psicológico es contraria a la calidad de ser sintiente, de conformidad con la definición y consideraciones que sobre ese concepto he hecho, sin

\footnotetext{
4444 MOLANO. A \& MURCIA, D. Animales y naturaleza como nuevos sujetos de derecho: un estudio de las decisiones judiciales más relevantes en Colombia (Bogotá 2018) 90

${ }^{45}$ Cámara Federal de Casación Penal, Sala II, CCC68831/2014/CFCI, 2015, Parte Resolutiva.

${ }^{46}$ Tercer Juzgado de Garantías del Poder Judicial de Mendoza, P-72.254/15, 2016, p. 33

${ }^{47}$ MOLANO. A \& MURCIA, D. Animales y naturaleza como nuevos sujetos de derecho: un estudio de las decisiones judiciales más relevantes en Colombia (Bogotá 2018) 90

${ }^{48}$ Código Civil de Colombia. Artículo 1504. modificado por el artículo 57 de la Ley 1996 de 2019. INCAPACIDAD ABSOLUTA Y RELATIVA: Son absolutamente incapaces los impúberes. Sus actos no producen ni aún obligaciones naturales, y no admiten caución. Son también incapaces los menores púberes. Pero la incapacidad de estas personas no es absoluta y sus actos pueden tener valor en ciertas circunstancias y bajo ciertos respectos determinados por las leyes. Además de estas incapacidades hay otras particulares que consisten en la prohibición que la ley ha impuesto a ciertas personas para ejecutar ciertos actos.

${ }^{49}$ MOLANO. A \& MURCIA, D. Animales y naturaleza como nuevos sujetos de derecho: un estudio de las decisiones judiciales más relevantes en Colombia (Bogotá 2018) 92
}

124 Derecho Animal. Forum of Animal Law Studies, vol. 12/3 
importar la finalidad de la acción mediante la cual se cause ese daño. Por supuesto, considerando, que la sintiencia es un medio para alcanzar el fin de la existencia continuada (vivir), debería extraerse como conclusión que la vida es un derecho que se deriva de la sintiencia.

Conectado con el punto anterior, el cuarto aspecto a resaltar, es el hecho que la sentencia indica que la categoría de sujeto de derecho es aplicable a los primates con motivo de las similitudes entre estos y el ser humano, pero muchas de las características que se señalan no pueden predicarse solo de los grandes simios. El ser de carne y hueso, nacer, sufrir, beber, jugar, dormir y querer, no son atributos exclusivos de los grandes simios, sino compartidos con una amplia gama de animales no humanos.

En ese sentido, considero que debería entenderse que un animal es titular de derechos en cuanto es un ser sintiente y, como tal, se le deben reconocer los derechos asociados necesariamente a esta condición, aquellos que son inherentes ella, que desde mi perspectiva son, como mínimo, el derecho a la vida, a la dignidad, a la integridad y a la libertad, derechos cuyo contenido desarrollaré más adelante. Esto, por supuesto, debería ser reconocido según las características que son propias de cada animal, puesto que las condiciones que pueden dar una vida que sea posible catalogar como digna a un animal de una especie pueden ser totalmente desfavorables y dañinas para otro. Un punto de partida para el reconocimiento de estos derechos puede ser la observancia de las cinco libertades de los animales propuestas por la OiE, de las que hablé anteriormente, a saber, "vivir 1) libre de hambre, de sed y de desnutrición; 2) libre de temor y de angustia; 3) libre de molestias físicas y térmicas; 4) libre de dolor, de lesión y de enfermedad; 5) [ser] libre de manifestar un comportamiento natural". ${ }^{50}$

Lo anterior, considero es particularmente relevante en la medida en que existen derechos que son reconocidos a los seres humanos cuyo reconocimiento puede reducirse al respeto a la calidad de sintientes que tienen estos, como lo son el derecho a la vida ${ }^{51}$, a no ser sometido a torturas o tratos crueles ${ }^{52}$, el derecho al descanso ${ }^{53}$, "derecho a un nivel de vida adecuado que le asegure (...) la salud y el bienestar, y en especial la alimentación" ${ }^{2}$, y, en este aspecto, el de la sintiencia, no hay una diferencia relevante entre los humanos y los animales no humanos que justifique el reconocimiento de estos derechos a los primeros y no a los segundos.

\subsubsection{Caso del Elefante Kaavan. Sentencia de la Alta Corte de Islamabad de 25 de abril de 2020.}

Kaavan es un elefante asiático, obsequio del Gobierno de Sri Lanka al de Pakistán, que desde 1985 habita en un pequeño recinto en el Zoológico Marghazar, del Territorio Federal de Islamabad, sin las condiciones apropiadas para suplir los requerimientos fisiológicos, sociales y comportamentales de su especie, al punto que el elefante mostraba comportamientos que eran muestra de su soledad, angustia y sufrimiento ${ }^{55}$.

En este caso, la Alta Corte de Islamabad señala que fue llamada a reconocer que los animales tienen derechos que deben ser respetados o, más bien, que es el deber de la especie humana proteger estos derechos ${ }^{56}$. En este caso, además, se hicieron peticiones particulares con respecto a la reubicación de algunos de los animales del zoológico, entre ellos un oso negro, además del elefante Kaavan. Al fijar los términos sobre los cuáles ha sido llamada a decidir, esta corte señala que el asunto es si los animales, o criaturas vivientes no humanas, tienen derechos independientes, y si hay un deber por parte de la raza humana, a través del Estado y sus funcionarios públicos, de proteger, preservar y conservar estas especies.

En el desarrollo del fallo, la corte hace una serie de consideraciones sobre las condiciones en las que se tenía al animal en este zoológico, como lo hace también sobre otros de los animales que se encontraban en este recinto, para luego hacer un estudio sobre qué autoridad tiene la facultad o poder para administrar los asuntos del zoológico según la ley, señalando una serie de normas relevantes para dilucidar esta cuestión, y, finalmente, llegar al tema que considero relevante para efectos del presente estudio, a saber, en términos de la sentencia, si los animales tienen derechos y si hay un deber por parte del Estado y de la especie humana de proteger el bienestar de las otras especies animales.

Para responder a los interrogantes planteados anteriormente, la corte hace referencia a la Declaración Universal de los Derechos del Animal, y cita jurisprudencia y casos de otros países. Entre los casos que menciona, el de la orangutana Sandra y la chimpancé Cecilia, en Argentina, así como otros ocurridos en India,

\footnotetext{
${ }^{50} \mathrm{https}: / /$ www.oie.int/es/bienestar-animal/el-bienestar-animal-de-un-vistazo/

${ }^{51}$ Art. 3 Declaración Universal de los Derechos Humanos

${ }^{52}$ Art. 5 Declaración Universal de los Derechos Humanos.

${ }^{53}$ Art. 24 Declaración Universal de los Derechos Humanos

${ }^{54}$ Art. 25. Declaración Universal de los Derechos Humanos.

${ }^{55}$ Sentencia de la Alta Corte de Islamabad de 25 de abril de 2020 (W.P. 1155/2019)

${ }^{56}$ Sentencia de la Alta Corte de Islamabad de 25 de abril de 2020 (W.P. 1155/2019) P. 4
} 
Estados Unidos, Sur África, y otros más que tuvieron lugar en Pakistán. Finalmente, hace mención al tratamiento que hacen varias religiones de los animales, sin embargo, este último aspecto no será tratado acá.

Luego de este análisis, la Corte concluye que es obvio que hay consenso en que un animal no es meramente una cosa o propiedad, y que no hay disputa en cuanto a que ningún animal merece ser sometido a tratos crueles, para, finalmente, preguntarse si los animales tienen derechos legales, a lo que señala que la respuesta es, sin ninguna duda, afirmativa ${ }^{57}$. Posteriormente, la Alta Corte de Islamabad expresa que "la vida, entonces, es la premisa de la existencia de un derecho. Ya sean derechos humanos, o derechos garantizados expresamente bajo la constitución, todos tienen un nexo con la "vida". Un objeto o cosa sin "vida" no tiene derecho. Un ser vivo, por otro lado, tiene derechos con motivo del regalo de la "vida". Un animal, sin lugar a dudas, es un ser sintiente. Tiene emociones y puede sentir dolor o gozo. [...] Como los humanos, los animales también tienen derechos naturales que deben ser reconocidos. Es un derecho de cada animal, un ser sintiente, el vivir en un ambiente que cumpla con sus necesidades comportamentales, sociales y fisiológicas. [...] Los humanos no pueden arrogarse a sí mismos el derecho o prerrogativa de esclavizar o subyugar un animal, porque este ha nacido libre para propósitos específicos. Es el derecho natural de un animal el no ser torturado o matado innecesariamente, porque el regalo de la vida que posee es precioso y su irrespeto socava el respeto al Creador". ${ }^{58}$

Sobre esta sentencia, consideramos sumamente importante que se parta del supuesto que la vida es la premisa de la existencia de un derecho, el darle valor a la vida en sí misma, y que esto se conecte con la sintiencia, como elemento que debe dar lugar al reconocimiento de derechos específicos de un animal con miras a la satisfacción de sus necesidades de diversa índole. Así mismo, es importante que se enfatice en esta decisión que los humanos no tienen el derecho a esclavizar o subyugar otros animales, en la medida en que ellos han nacido libres, lo cual puede verse como es una aproximación al derecho a la libertad de los animales no humanos, como uno de los derechos que pueden serles reconocidos. Dejo de lado explícitamente aquellos argumentos de índole religiosa que se plantean en la sentencia, en la medida en que este estos no pueden ser utilizados como un factor común con legislaciones que no tengan como fuente el Corán.

\section{El caso concreto de Colombia: legislación y jurisprudencia relevante.}

\subsection{Legislación.}

\subsubsection{Estatuto Nacional de Protección de los Animales. Ley 84 de 1989.}

En Colombia se estableció el Estatuto Nacional de Protección de los Animales mediante la Ley 84 de 1989. Esta norma señaló que, en el territorio colombiano, los animales gozarían de "especial protección contra el sufrimiento y el dolor, causados directa o indirectamente por el hombre" ${ }^{59}$, y señalaba dentro de sus objetivos el "promover la salud y el bienestar de los animales" así como "erradicar y sancionar el maltrato y actos de crueldad para con los animales" y "prevenir y tratar el dolor y el sufrimiento de los animales"60.

Esta norma, así mismo, señalaba una serie de deberes hacia los animales, entre los que se establecía, un deber general de respetarles y de abstenerse de causarles daños o lesiones, y unos deberes particulares que se imponían al "propietario, tenedor o poseedor de un animal" ${ }^{1}$, relativas a mantener al animal en condiciones locativa apropiadas, suministrarle comida y bebida suficientes (en cantidad y calidad), así como los medicamentos y cuidados necesarios para preservar su salud y bienestar, y evitarle daño, enfermedad o muerte $\mathrm{y}$, también, suministrarle abrigo apropiado contra la intemperie.

Finalmente, cabe resaltar que esta ley señalaba que quien causara daño a un animal o realizara cualquier conducta de las que en ella se indicaban y calificaban como crueles con los animales, sería sancionado de conformidad con la pena prevista para cada caso (art. 6), y posteriormente determinaba "las penas y agravantes" ${ }^{\prime 2}$ de estas, que consistían sanciones económicas o arresto de hasta seis (6) meses. Esta ley determinaba algunas excepciones a lo que podía considerarse como daño o como una conducta cruel hacia los animales, entre las cuales incluía actividades que implican necesariamente daño y crueldad con los animales, pero que se desarrollaban en el marco de "espectáculos", a saber, el rejoneo, el coleo, las corridas de toros,

\footnotetext{
${ }^{57}$ Sentencia de la Alta Corte de Islamabad de 25 de abril de 2020 (W.P. 1155/2019) P. 7

${ }^{58}$ Sentencia de la Alta Corte de Islamabad de 25 de abril de 2020 (W.P. 1155/2019) p. 60.

${ }^{59}$ Ley 84 de 1989 , artículo $1^{\circ}$

${ }^{60}$ Ley 84 de 1989, artículo2 ${ }^{\circ}$

${ }^{61}$ Ley 84 de 1989, artículo 4

${ }^{62}$ Ley 84 de 1989, Capítulo IV.
} 
novilladas, corralejas, becerradas, tientas y riñas de gallos ${ }^{63}$, y también los "actos de aprehensión o apoderamiento en la caza y pesca deportiva, comercial, industrial, de subsistencia o control de animales silvestres, bravíos o salvajes" ${ }^{\text {"64 }}$ y la muerte de plagas domésticas o agropecuarias, siempre que esto último se llevara a cabo de conformidad con lo señalado por el Ministerio de Agricultura o las autoridades sanitarias. En ese sentido, aunque la norma incluyera preceptos tendientes a la protección animal, quedaban permitidos los daños y tratos crueles hacia los animales en diversos casos, muchos de estos, básicamente, para diversión y entretenimiento del ser humano.

\subsubsection{Reconocimiento legal de la sintiencia en Colombia. Ley 1774 de 2016.}

Posteriormente, los animales son reconocidos legalmente como seres sintientes en virtud de la Ley 1774 de 2016. Esta norma modificó el Código Civil, el Código Penal y el Estatuto Nacional de Protección de los Animales de Colombia, y en su artículo $1^{\circ}$ señaló, precisamente, que "[1] os animales como seres sintientes no son cosas, recibirán especial protección contra el sufrimiento y el dolor, en especial, el causado directa o indirectamente por los humanos".

Con base en el reconocimiento legal que se hace de la sintiencia de los animales, esta norma señala tres principios $^{65}$, que son:

1. La protección animal: En virtud de este principio el trato a los animales debe basarse en el "respeto, la solidaridad, la compasión, la ética, la justicia, el cuidado, la prevención del sufrimiento, la erradicación del cautiverio y el abandono, así como cualquier forma de abuso, maltrato, violencia y trato cruel".

2. El bienestar animal: Este principio señala que en el cuidado de los animales la persona que sea responsable de aquellos, o su tenedor, (acá cabe señalar que no se hace referencia en la ley a un propietario o dueño del animal) debe asegurar como mínimo que los animales no sufran hambre o sed, que no sufran malestar físico ni dolor injustificado, que no sufran enfermedades por negligencia o descuido, que no sean sometidos a condiciones de miedo o estrés, y que puedan manifestar su comportamiento natural. Estos cinco aspectos reflejan, aunque con leves diferencias en el orden en que son agrupados, las cinco libertades señaladas por la Organización Mundial de Sanidad Animal (World Organization for Animal Health - OiE), "para describir los derechos que son responsabilidad del hombre [el ser humano]"66 en materia de bienestar animal.

3. La solidaridad social. Este principio establece la obligación por parte del Estado, la sociedad y sus miembros de asistir y proteger a los animales con acciones diligentes ante situaciones que pongan en peligro su vida, su salud o integridad física, así como tomar parte activa en la prevención y eliminación del maltrato, la crueldad y la violencia contra los animales.

Finalmente, aunque la Ley 1774 tiene otra serie de elementos relevantes, para los efectos de este texto, basta expresar que, además del reconocimiento de la sintiencia y de los principios señalados anteriormente, esta ley modifica el Código Penal e introduce en él los artículos 339A y 339B, los cuales regulan, respectivamente, los "Delitos contra la vida, la integridad física y emocional de los animales" 67 y sus circunstancias de agravación punitiva, delitos para los cuales estableció una pena de prisión de doce (12) a treinta y seis (36) meses. Estas penas pueden ser aumentadas de la mitad a tres cuartas partes si se incurre en una de las circunstancias de agravación punitiva del artículo 339B, además de penas de inhabilidad para el ejercicio de profesiones, oficios, comercio o tenencia relacionada con animales y multas económicas.

Sin embargo, a pesar del reconocimiento que se hace del estatus de seres sintientes de los animales, se mantienen como excepciones, y se exceptúan de las penas previstas en la ley, las conductas señaladas anteriormente que se incluyen en el artículo $7^{\circ}$ de la Ley 84 de 1989 y, además, "las prácticas, en el marco de las normas vigentes, de buen manejo de los animales que tengan como objetivo el cuidado, reproducción, cría, adiestramiento, mantenimiento; las de beneficio y procesamiento relacionadas con la producción de alimentos; y las actividades de entrenamiento para competencias legalmente aceptadas" ${ }^{68}$ y "Quienes adelanten acciones

\footnotetext{
${ }^{63}$ Ley 84 de 1989, artículo 7

${ }^{64}$ Ley 84 de 1989, artículo 8

${ }^{65}$ Ley 1774 de 2016, artículo 3

${ }^{66}$ Organización Mundial de Sanidad Animal. https://www.oie.int/es/bienestar-animal/el-bienestar-animal-de-un-vistazo/

${ }^{67}$ Ley 1774 de 2016, artículo 5

${ }^{68}$ Ley 1774 de 2016, artículo 5, parágrafo 1.
} 
de salubridad pública tendientes a controlar brotes epidémicos, o transmisión de enfermedades zoonóticas, no serán objeto de las penas previstas en la presente ley". ${ }^{69}$

\subsubsection{Producción de productos cárnicos y derivados, destinados para el consumo humano, y producción de leche. Decreto 616 de 2006 y Decreto 1500 de 2007.}

El Decreto 616 de 2006 establece el reglamento técnico "Sobre los requisitos que debe cumplir la leche para el consumo humano que se obtenga, procese, envase, transporte, comercialice, expenda, importe o exporte en el país". En este decreto no se hace siquiera mención al bienestar de los animales que son explotados en el proceso de producción de leche, sin embargo, el artículo $3^{\circ}$ hace referencia a las "Buenas prácticas en la alimentación animal" en este sentido: "Modos de empleo y prácticas recomendadas en la alimentación animal tendientes a asegurar la inocuidad de los alimentos de origen animal para consumo humano, minimizando los riesgos físicos, biológicos y químicos para la salud de los consumidores" (Negrita fuera del texto). La lectura de este aparte del artículo $3^{\circ}$ hace evidente que no hay en realidad una preocupación por la salud de los animales, sino que el interés por su alimentación es simplemente una forma de velar por la salud de los consumidores, es decir, utilizando a los animales como simples objetos de explotación.

Por otro lado, el Decreto 1500 de 2007 establece el "reglamento técnico a través del cual se crea el Sistema Oficial de Inspección, Vigilancia y Control de la Carne, Productos Cárnicos Comestibles y Derivados Cárnicos, destinados para el Consumo Humano y los requisitos sanitarios y de inocuidad que se deben cumplir en su producción...". Considero que el aspecto más llamativo del mismo, es que, incluso en un tipo de práctica que implica el mayor daño posible a un ser sintiente, el acabar con su vida, se habla del bienestar del animal, específicamente, del bienestar de los animales en las instalaciones (con relación a su mantenimiento, ubicación y diseño) y áreas de los predios producción ${ }^{70}$, así como en el transporte de los animales ${ }^{71}$, aunque en todos los casos se hace de forma superficial.

\subsubsection{Prohibición de los vehículos de tracción animal. Ley 769 de 2002.}

Esta Ley, mediante la cual se adoptó el Código Nacional de Tránsito Terrestre de Colombia, prohíbe en su artículo 98 el tránsito urbano en municipios de categoría especial y de primera categoría del país, de vehículos de tracción animal. Sin embargo, en el parágrafo del mismo artículo se señala que quedan exceptuados de esta prohibición los vehículos de tracción animal utilizados para fines turísticos.

En ese sentido, se observa que no se prohíbe el tránsito o el uso de vehículos de tracción animal en todos los municipios del país y, adicionalmente, que se permite la explotación de animales en vehículos de este tipo para fines turísticos, lo que, por supuesto, no es una justificación suficiente para explotar animales (si es que, acaso, existe alguna), en la medida en que es una muestra de uso de los animales como objetos, no como seres vivos y sintientes, para entretenimiento y satisfacción de intereses de los seres humanos, obligando a estos animales a realizar conductas que evidentemente no son naturales para ellos, que les impone realizar esfuerzos importantes y que pueden producirles afectaciones en su salud.

Frente a este tema, adicionalmente, el Decreto 178 de 2012 (recopilado en el Decreto 1079 de 2015) reguló las medidas relacionadas con la sustitución de los vehículos de tracción animal que debían llevarse a cabo en los municipios donde se prohibía esta actividad de acuerdo con la Ley 769 de 2002.

\subsubsection{Animales de asistencia o "ayudas vivas". Decreto 1660 de 2003, recogido en el Decreto 1079 de 2015 (Único Reglamentario del Sector Transporte).}

El Decreto Reglamentario 1079 de 2015, define las ayudas vivas como "los animales de asistencia que facilitan la accesibilidad de las personas con discapacidad" ${ }^{\prime 2}$, y señala los requisitos necesarios para que se entienda que un perro es un "perro de asistencia". Así, establece que ellos deben tener la acreditación de adiestramiento en centros nacionales o internacionales que pertenezcan a, o sean homologados por, la Asociación Colombiana de Zooterapia. Así mismo, se determina la información que debe estar incluida en el carné del animal, los requisitos sanitarios correspondientes que debe cumplir y las vacunas que debe tener, así como "las condiciones de uso de perros de asistencia" (ni siquiera se hace referencia a una prestación de un servicio por parte del animal, sino directamente de su uso como un objeto), dentro de las cuales se encuentra

\footnotetext{
${ }^{69}$ Ley 1774 de 2016, artículo 5, parágrafo 2.

${ }^{70}$ Decreto 1500 de 2007. Artículos 12 y 16.

${ }^{71}$ Decreto 1500 de 2007. Artículo 19

${ }^{72}$ Decreto Reglamentario 1079 de 2015. Artículo 2.2.7.4

128 Derecho Animal. Forum of Animal Law Studies, vol. 12/3
} 
que deben utilizar chalecos que los identifiquen, arnés y, si se exige por parte del prestador del servicio de transporte, que lleven un bozal puesto.

Cabe señalar, claro, que el Decreto donde se encontraban estas disposiciones originalmente (Decreto 1660 de 2003) reglamenta "la accesibilidad a los modos de transporte de la población en general y en especial de las personas con discapacidad", de modo que no sorprende que no se traten temas sobre el bienestar y las condiciones de los animales. Sin embargo, ya he mencionado, es evidente el uso de los animales como un objeto, de acuerdo con el lenguaje utilizado en la norma, en vez de que se les conceda un estatus de seres sintientes que prestan un servicio.

\subsubsection{Uso de "medio canino" por parte de empresas de vigilancia y seguridad privada. Decreto 2187 de 2001, recogido en el Decreto Reglamentario 1070 de 2015 (Único Reglamentario del Sector Defensa).}

En esta norma se regula el uso de perros dentro de los servicios prestados por parte de empresas de vigilancia y seguridad privada. Esta norma determina una jornada máxima a la cual pueden ser sometidos los perros que presten este tipo de servicio ( 8 horas por turno) y define que, en caso que no se puedan trasladar para el cambio de turno estos perros dentro de los puestos de trabajo, deberán contar con sitios especiales de descanso, que sean adecuados, excluyendo los guacales de transporte, por lo que deben proveerse de "caniles o jaulas portátiles" que permitan al canino moverse dentro de los mismos, con la posibilidad de ser alimentados y que reciban de beber ${ }^{73}$. Así mismo, se determina que quienes empleen perros para este tipo de servicios deberán contar dentro de sus instalaciones con un sitio apropiado para la atención médico-veterinaria en primeros auxilios, que tenga las debidas condiciones de higiene y salubridad para atender enfermedades o accidentes que sufran los perros ${ }^{74}$.

En este caso es importante señalar que sí se establecen medidas de protección del bienestar de los animales que son empleados para dichas actividades. Sin embargo, considero que es una reglamentación insuficiente, ya que, por ejemplo, se indica que la jornada podrá ser de máximo 8 horas por turno, pero no se señala si ello es un máximo diario, o cuánto tiempo de descanso debe dársele al animal antes de imponerle de nuevo un turno de 8 horas. Asimismo, no se determinan, por ejemplo, las dimensiones que deben tener los "caniles o jaulas" que se dispongan para que el perro descanse cuando no pueda ser transportado por cambio de turno. Solo se señala que pueda moverse y, por supuesto, un espacio que apenas permita movimiento, y recibir comida y bebida se ajustaría a esta norma, pero sería evidentemente una violación de los derechos de los animales.

\subsubsection{Bienestar en animales de producción. Decreto 2113 de 2017 y Resolución 136 de 2020.}

Estas normas son posteriores al reconocimiento del estatus de seres sintientes de los animales hecho por la Ley 1774 de 2016, aspecto que es señalado dentro del considerando del Decreto 2113 de 2017, cuyo objeto es "establecer las disposiciones y requerimientos generales para el Bienestar Animal en las especies de producción del sector agropecuario" ". Esta norma tiene dentro de sus fundamentos y consideraciones las cinco libertades estipuladas por la $\mathrm{OiE}$, y expresa que Colombia, como miembro de aquella, ha comenzado a implementar sus recomendaciones sobre bienestar animal, como parte de su responsabilidad social en el marco del sistema de medidas sanitarias y fitosanitarias y su efecto "sobre la inocuidad alimentaria nacional, así como para cumplir requisitos de admisibilidad sanitaria hacia mercados internacionales"76.

Asimismo, y esto es algo importante a tener en cuenta, se señala en las consideraciones de este decreto que "Se pretende posicionar el Bienestar Animal para las especies de producción con el fin de brindarles un trato ético que optimice su salud y la producción, y mejore los parámetros de calidad e inocuidad de los productos que de ellas se derivan". Esta frase llama la atención, en la medida en que, al mismo tiempo, se indica que se quiere dar a los animales un trato ético teniendo en la mira la salud de aquellos, y, que ese trato derive en unos mejores productos extraídos de la explotación y, finalmente, de la muerte de esos mismos animales. Parece difícil creer que pueda darse un trato ético a un ser sintiente concibiéndolo como un medio y objeto de explotación. Dar ciertas condiciones de bienestar no puede ser considerado como un "trato ético", teniendo en cuenta la finalidad de la actividad en la que se enmarca este decreto. Igualmente, es importante señalar que, líneas más delante a la mención del trato ético, dice el decreto que "mejorando las condiciones de vida de los animales en los sistemas de producción se aumenta la productividad", evidenciando nuevamente

\footnotetext{
${ }^{73}$ Decreto 1070 de 2015. Artículo 2.6.1.1.3.3.6

${ }^{74}$ Decreto 1070 de 2015. Artículo 2.6.1.1.3.3.7

${ }^{75}$ Decreto 2113 de 2017. Artículo 2.13.3.5.1.

${ }^{76}$ Decreto 2113 de 2017. Consideraciones.
} 
que se dan ciertas condiciones de bienestar a los animales, pero no con el objeto de protegerlos, sino de buscar mayores beneficios para el ser humano.

En todo caso, el decreto tiene aspectos que son bastante importantes en materia de bienestar animal, más allá de las consideraciones éticas y sobre su motivación, en la medida en que incluye como principios del bienestar animal las 5 libertades señaladas por la OiE, las cuales plasma en el siguiente sentido: [Que el animal esté] 1) libre de hambre, sed y desnutrición; 2) libre de temor y angustia; 3) libre de molestias físicas y térmicas; 4) libre de dolor, de lesión y de enfermedad; 5) libre de impedimentos de manifestar un comportamiento natural. En el mismo sentido, esta norma determina los aspectos generales que deben ser tenidos en cuenta con relación al bienestar de los animales, como los aspectos ambientales (que incluye las superficies donde se encuentren y desplacen los animales, donde estos descansen, y que se les permita a los animales hacer movimientos seguros y cómodos, así como realizar sus comportamientos naturales), que se permita su interacción y agrupamiento social, la calidad del aire y la temperatura, el acceso a comida y agua, entre otros.

Posteriormente, fue expedida la Resolución 136 de 2020 por parte del Ministerio de Agricultura y Desarrollo Rural, en la cual se adopta el "Manual de Condiciones de Bienestar Animal propias de cada una de las especies de producción en el Sector Agropecuario para las especies Équidas, Porcinas, Ovinas y Caprinas", esto, dado que el Decreto 2113 de 2017 señalaba, en su artículo 2.13.3.5.8 que este Ministerio debía adoptar normas necesarias para precisar las condiciones de bienestar animal propias de cada una de las especies de producción en el sector agropecuario. Así, este manual se enmarca, también, dentro de los principios señalados en el Decreto 2113 de 2017, y establece lineamientos sobre la libertad de movimiento, las instalaciones, la bebida y alimento, condiciones de sanidad, condiciones de bienestar térmico, de las prácticas que generen dolor y el sacrificio humanitario o eutanasia, entre otros aspectos.

\subsubsection{Prohibición de la experimentación, importación, fabricación y comercialización de productos cosméticos, sus ingredientes o combinaciones de ellos que sean objeto de pruebas con animales. Ley 2047 de 2020.}

Esta ley, expedida en agosto de 2020, es de suma importancia por la materia que regula y las prohibiciones que establece, y considero que es de resaltar el que no prohíbe solo la experimentación en animales para fines cosméticos, que puede considerarse como el punto de partida para la terminación de la explotación de animales para estos fines, sino que además prohíbe la importación, exportación, fabricación y comercialización de productos, y sus ingredientes o combinaciones, que hayan sido objeto de pruebas con animales, lo que implica ir más allá, es dar un paso adicional que trasmite un mensaje claro de rechazo contundente a la experimentación y pruebas en animales para fines cosméticos.

Esta norma, en todo caso, establece dos excepciones a estas prohibiciones:

1. Cuando un ingrediente deba someterse a pruebas de seguridad, por riesgos de salud y/o ambiente y no existan pruebas alternativas validadas por la comunidad científica internacional. ${ }^{77}$

2. Cuando los datos de seguridad generados a través de pruebas en animales para un ingrediente se hayan realizado para otro propósito diferente al cosmético. ${ }^{78}$

La primera de estas excepciones, sin embargo, muestra cómo los intereses y la salud de los animales tienen una consideración inferior a los intereses de los seres humanos, en la medida en que se considera que, si un ingrediente puede representar un riesgo para la salud de los humanos y/o para el medio ambiente, entonces se autoriza probarlo en animales no humanos ¿no importa, entonces, que ese ingrediente pueda ser nocivo para la salud de los animales en los que se experimentará? Si se le diera a la vida y salud de los animales no humanos una importancia acorde con la calidad que tienen de seres sintientes, debería reconocerse que los fines cosméticos no son justificación para someterlos a un riesgo a su salud.

Por otro lado, entendemos que la segunda excepción no permite la experimentación en animales para fines cosméticos directamente, si bien puede abrir una puerta peligrosa a que se disfracen los fines con los cuales se realizan los experimentos o pruebas, para efectos de continuar con estas prácticas con fines cosméticos.

Esta ley incluye un punto que merece ser resaltado, y es la concesión de "estímulos, incentivos y facilidades para el fortalecimiento de las capacidades de los laboratorios e instituciones de investigación

\footnotetext{
${ }^{77}$ Ley 2047 de 2020. Art. 3, numeral 1.

${ }^{78}$ Ley 2047 de 2020. Art. 3, numeral 2.
} 
nacionales que desarrollen y apliquen modelos alternativos para evitar el uso de pruebas en animales en esta industria, validadas por la comunidad internacional"79. Esto es relevante en la medida en que la concesión de incentivos y la imposición de mecanismos para desincentivar (no necesariamente sanciones) es un medio que considero de la mayor importancia para generar un cambio en las industrias que explotan animales, ya que finalmente esta explotación tiene detrás intereses económicos, y si explotar animales deja de ser económicamente más llamativo que no hacerlo, pues estas industrias empezarán a explorar opciones alternativas.

\subsection{Jurisprudencia}

\subsubsection{Sentencia C-666 de 2010 - Corte Constitucional de Colombia}

En la C-666 de 2010 de la Corte Constitucional de Colombia, en la cual se decide una acción de inconstitucionalidad frente al artículo $7^{\circ}$ de la Ley 84 de 1989 (Estatuto de Protección de los Animales), en el cual se exceptúan ciertas actividades (rejoneo, coleo, corridas de toros, novilladas, corralejas, becerradas, riñas de gallos) llamadas "culturales", de la calificación de crueldad animal, contra toda lógica.

En este caso, la cuestión a revisar era "si las actividades del artículo 7 se consideran expresiones culturales y si son acordes a la Constitución, teniendo en cuenta que en Colombia está prohibido el maltrato animal" ${ }^{\prime \prime 0}$, frente a lo cual encontró esta Corte que dicha norma no violaba la Constitución colombiana y declarándola, entonces, exequible (aunque condicionalmente). En ese sentido, expresó la Corte Constitucional "que pueden existir diversas fuentes de justificación para exceptuar el deber constitucional [de protección a los animales] en cuestión", y entre estas fuentes señaló la libertad religiosa, los hábitos alimenticios de los seres humanos, la investigación y experimentación médica y, finalmente, las expresiones sociales y culturales, motivo por el cual determinó que el artículo $7^{\circ}$ en cuestión no violaba la Constitución colombiana. ${ }^{81}$ Así mismo, en esta sentencia se da a entender que los límites señalados anteriormente son parte de una enunciativa, mas no restrictiva, pero que los límites a la protección de los animales no se reduce solo a estos aspectos.

En ese sentido, siendo las actividades señaladas anteriormente expresiones culturales que, por lo tanto, cuentan con una justificación legítima para excepcionar el deber de protección animal, pero sujetas a una serie de limitaciones, como que "se garantice en la mayor medida posible el deber de protección animal", así como limitaciones de índole territorial, limitaciones sobre las ocasiones en que puede darse, así como otras sobre su contenido (solo aquellas actividades señaladas expresamente en el artículo 7 de la Ley 84 de 1989), y sobre su financiación. ${ }^{82}$

En lo que toca al tema que ocupa este estudio, la Corte Constitucional indica que la naturaleza no es un elemento a disposición del hombre (seres humanos, debería ser el término utilizado), sino un conjunto del que estos hacen parte junto con los otros seres sintientes ${ }^{83}$, y en esa medida, indica que "Así, el deber constitucional de protección de los recursos naturales resulta fundamento eficaz para alcanzar dicho objetivo y constituir el bienestar animal en parámetro constitucional de interpretación de todas las normas infraconstitucionales que, de cualquier forma, regulen las relaciones de las personas con los animales" ${ }^{" 4}$.

En este punto, vale la pena volver sobre lo dicho por Andrea Padilla, quien expresa que una de las tendencias en la jurisprudencia latinoamericana (aunque esta sentencia sea ya de hace diez años), es la de la protección de los animales a través de la salvaguarda al medio ambiente. Al respecto, señala Padilla que "[1]a vía que vienen tomando los jueces latinoamericanos para darle fundamento constitucional a la protección de los animales, es la de los derechos ambientales. Ante la falta de mención explicita a los animales en la mayoría de las constituciones políticas, puede decirse que el mérito de los jueces ha sido usar estos derechos para hacer existir a los animales y extraer de ellos un mandato de protección especial. De hecho, no es impreciso afirmar que el avance del derecho de los animales se está dando por la vía del "ecologismo jurídico"' (2019, pág. 395).

Así mismo, Padilla (2019, pág. 400) señala que otro medio ha sido la protección de los animales por la vía de la dignidad humana. $\mathrm{Al}$ respecto, expone que este planteamiento se fundamenta en la "idea de que la dignidad es o debería ser causa de comportamientos compasivos con los demás animales e impedir tratos crueles en su contra o mitigar su dolor y sufrimiento. Expresado en otros términos, el argumento sugiere que

\footnotetext{
${ }^{79}$ Ley 2047 de 2020. Art. 3, numeral 4.

${ }^{80}$ MOLANO. A \& MURCIA, D. Animales y naturaleza como nuevos sujetos de derecho: un estudio de las decisiones judiciales más relevantes en Colombia (Bogotá 2018) 95.

${ }^{81}$ Corte Constitucional. Sentencia C-666, del 30 de agosto de 2010.

${ }^{82}$ Corte Constitucional de Colombia, sentencia C-666 de 2010, fundamento 2.

${ }^{83}$ MOLANO. A \& MURCIA, D. Animales y naturaleza como nuevos sujetos de derecho: un estudio de las decisiones judiciales más relevantes en Colombia (Bogotá 2018) 95.

${ }^{84}$ Corte Constitucional. Sentencia C-666 de 2010. Fundamento 2.1.
} 
de la dignidad emana una suerte de código moral en gracia del cual los seres humanos (agentes morales) debemos expresar comportamientos dignos hacia los animales".

Tal vez el aspecto más relevante de esta sentencia, es que indica expresamente que los animales son seres sintientes, es decir, declara expresamente este reconocimiento, que no es poca cosa, en la medida en que al tratarse de una sentencia de constitucionalidad tiene efectos erga omnes, es decir, aplicables a todos, es una sentencia con efectos generales, y no solo frente a quienes son parte dentro de un proceso.

Ahora bien, un punto que quiero simplemente mencionar es el de la justificación de la "cultura" para efectos de maltratar y matar animales. Aunque sobre este asunto podrían traerse a colación muchos casos y citar precedentes en Sur América, España o Francia, me parece inconcebible que se pueda justificar una práctica cruel con la excusa de la "cultura". En mi opinión, esto es una muestra clara de una aproximación antropocéntrica al maltrato animal, en que se da prevalencia a los intereses humanos, aunque sean intereses de menor valor (cultura vs vida), como se observa, por ejemplo, en estas expresiones de la Corte Constitucional:

En este sentido, para la Sala la armonización del deber de protección animal y el hecho concreto de que ciertas actividades que implican maltrato a los animales sean tradiciones en determinados municipios o distritos colombianos conduce a un condicionamiento de extensión o inclusión en concreto: que sean estas las únicas actividades de maltrato animal cuya realización se permite;

\section{$[\ldots]$}

Las manifestaciones culturales en las cuales está permitido el maltrato animal son aquellas mencionadas por el artículo 7 de la Ley 84 de 1989, no se entienden incluidas dentro de la excepción al deber de protección animal otras expresiones que no hayan sido contempladas en la disposición acusada. ${ }^{85}$

El hecho de que haya una práctica continuada de maltrato animal en una población, que date de tiempo atrás y tenga cierto nivel de arraigo, como mucho, debería ser un argumento en contra de la continuidad de las mismas, precisamente porque el desarrollo de la sociedad debe, en mi opinión, estar aparejado de la superación de discriminaciones, y de actos violentos como formas de entretenimiento o de obtener placer. Por supuesto, tampoco puede caerse en la ingenuidad e ignorar que en buena medida en la protección de este tipo de actividades median intereses políticos y económicos, y que la moral no es precisamente la que guía buena parte de las conductas humanas.

\subsubsection{Sentencia C-041 de 2017 - Corte Constitucional de Colombia}

Posteriormente, la Corte Constitucional profirió la Sentencia C-041 de 2017, en donde resolvió una acción de inconstitucionalidad contra el artículo $5^{\circ}$ de la Ley 1774 de 2016. En esta sentencia, la Corte señala que:

La dogmática evolutiva y dinámica impone avanzar en la concepción clásica y teórica del derecho. La Constitución, como lo ha recordado la jurisprudencia constitucional, es un instrumento viviente y abierto, que debe ajustarse a los cambios sociales, políticos, culturales e ideológicos para estar en consonancia con las diversas realidades, además que no puede pretender agotar todas y cada una de las respuestas posibles respecto a las múltiples problemáticas que surgen en el seno de la sociedad.

En esa medida, el poder judicial dotado por excelencia de la capacidad de control y de defensa del orden institucional, también es portador de la visión del interés general (arts. 113 y 241 inc. primero, C. Pol.). De ahí que el Tribunal Constitucional, a quien se le ha confiado la guarda de la integridad y supremacía del Estatuto Fundamental, deba realizar una reflexión interdisciplinaria, incluyente y sensible a las realidades de un mundo cambiante, para que los contenidos constitucionales no queden en letra muerta. Los derechos también son aquello que los jueces dicen a través de sus sentencias.

Aunque la Constitución no reconozca explícitamente a los animales como titulares de derechos, ello no debe entenderse como su negación, ni menos como una prohibición para su reconocimiento -innominados-. Su exigencia atiende a factores como la evolución de la humanidad y los cambios que

${ }^{85}$ Corte Constitucional de Colombia, Sentencia C-666 de 2010

132 Derecho Animal. Forum of Animal Law Studies, vol. 12/3 
presente una sociedad, lo cual puede llevar a la Corte a hacer visible lo que a primera vista no se avizora en la Constitución. Además, con independencia de la clasificación de los derechos en el tiempo (generacionales), forman una unidad por cuanto son interdependientes, integrales y universales (Negrita fuera del texto).

Aunque puedan hacerse algunos reproches en cuanto al comportamiento de la Corte Constitucional en su función como intérprete de la Constitución -en la medida en que muchas veces ha fungido, prácticamente, como legislador, al darle a algunas normas un alcance e interpretación realmente insospechados- considero que es importante que esta entiende que el derecho es dinámico y debe ajustarse a las realidades sociales, aspecto que ya fue mencionado páginas atrás, y esto necesariamente implica cambios en la consideración de los animales, y la apertura al reconocimiento de los derechos de aquellos.

Así mismo, como señalan en su estudio Molano y Murcia, hay una similitud entre lo considerado en este caso por la Corte Constitucional de Colombia y el caso expuesto de la sentencia de 2015 en Argentina, de la orangutana Sandra, en la medida en que "en esta Sentencia se aclara que los animales y los individuos humanos no son iguales. Pero sostiene que es posible "encausarlos dentro del sentido amplio de persona" (2018, pág. 97).

\subsubsection{Caso del Oso de Anteojos "Chucho" - Colombia}

Por último, encontramos el caso del Oso Chucho, el cual ha sido objeto de cuatro pronunciamientos por las altas cortes de Colombia (Corte Suprema de Justica y la Corte Constitucional). Chucho es un oso de anteojos que permaneció durante 18 años en la reserva de Río Blanco, en la ciudad de Manizales, y que fue enviado posteriormente al zoológico de Barranquilla, por lo que un ciudadano interpuso una acción de hábeas corpus en favor suyo, al considerar que con el traslado a ese zoológico quedaba condenado a un cautiverio permanente, lo cual contrario, en su opinión, al principio de protección animal señalado en la Ley 1774 de 2016.

1. Sentencia AHC4806-2017 - Corte Suprema de Justicia de Colombia. Sala Civil

2. Sentencia STL 12651-2017 - Corte Suprema de Justicia de Colombia. Sala Laboral.

3. Sentencia STP16597-2017 - Corte Suprema de Justicia de Colombia. Sala de Casación Penal.

4. Sentencia SU-016 de 2020 - Corte Constitucional.

\section{Sentencia AHC4806-2017 - Corte Suprema de Justicia de Colombia. Sala de Casación Civil}

Abordaré este estudio en orden cronológico, por lo que empezaré con la Sentencia AHC4806-2017 de la Sala Civil de la Corte Suprema de Justicia de Colombia, en la cual se resuelve la acción de habeas corpus en favor de Chucho. En esta sentencia, como señalan Murcia \& Molano, se pretendía que se reconociera a los seres sintientes "como sujetos de derecho o, lo que es lo mismo, con personalidad jurídica", para lo cual la Sala Civil adopta como estrategia el equiparar las nociones de persona y personalidad jurídica y la de sujeto de derecho, para extender la noción de persona a otras "entidades animadas". (Animales y naturaleza como nuevos sujetos de derecho: un estudio de las decisiones judiciales más relevantes en Colombia, 2018, pág. 97). Así mismo, las autoras señalan que la Sala Civil de la Corte Suprema de Justicia se apoya en el valor intrínseco de la naturaleza, y determina que este reconocimiento es un imperativo para detener el deterioro ambiental y los abusos contra los animales.

El aspecto fundamental de esta sentencia, creo, es el expreso reconocimiento de los animales como sujetos de derecho. Así, la Sala Civil señala que:

[e]n consecuencia, la nueva realidad a fin de sobrevivir impone señalar que no son sujetos de derecho exclusivamente los seres humanos, que también lo son las realidades jurídicas, algunas de las cuales por ficción jurídica son ya personas, como las "morales"; pero también, reclaman perentoriamente esa entidad, por poseerla ontológicamente, los otros seres sintientes, incluyendo la propia naturaleza. Si las realidades jurídicas fictas son sujetos de derechos, ¿por qué razón, quienes ostentan vida o son "seres sintientes" no pueden serlo?

Los otros seres sintientes también son sujetos de derechos indiscutiblemente. No se trata de darles derechos a los sujetos sintientes no humanos, iguales a los de los humanos equiparándolos en un todo, 
para creer que los toros, los loros, los perros o los árboles, etc, tendrán sus propios tribunales, sus propias ferias y festividades, sus juegos olímpicos o sus universidades; ni que los otros componentes de la naturaleza deban ser titulares de las mismas prerrogativas o garantías de los humanos, sino de reconocerles los correspondientes, los justos y convenientes a su especie, rango o grupo. ${ }^{86}$

Sin embargo, Murcia y Molano señalan precisamente que la "Corte, en lugar de presentar sus razones, pregunta: '[s]i las realidades jurídicas fictas son sujetos de derechos, ¿por qué razón, quienes ostentan vida o son "seres sintientes" no pueden serlo?' (Corte Suprema de Justicia de Colombia, AHC4806- 2017, 2017, considerando 2.4.3). Así, podemos identificar que no se ofrece ningún fundamento de la conclusión de que los animales son sujetos de derecho, por lo que parece que el argumento cae en una petición de principio". (2018, pág. 98)

En esta sentencia se señala que es viable reconocer el habeas corpus a un animal, en cuanto al ser titular de derechos es posible reconocer el derecho a la libertad en el que se fundamenta dicha acción (2.4.5.4), especialmente en consideración a que se trata de una especie protegida y por su papel dentro del ecosistema, razones por las cuales la Corte Suprema resuelve favorablemente esta cuestión, concede el habeas corpus y ordena a las entidades responsables el traslado del oso a una zona adecuada a su hábitat.

Murcia \& Molano señalan tres aspectos centrales en los que se asemeja esta sentencia a la de la Cámara Federal de Casación Penal sobre el caso de la orangutana Sandra: "[la sentencia] (i) sostiene que persona y ser sintiente no son sujetos de derecho en exacto sentido, pues no pueden concedérseles los mismos derechos (Cfr. Corte Suprema de Justicia de Colombia, AHC4806-2017, 2017, fundamento 2.4.5.2, p. 25) y, además, a los últimos no se les pueden imponer obligaciones (Corte Suprema de Justicia de Colombia, AHC4806-2017, 2017, parágrafo 2.4.5); (ii) les reconoce como derechos, exclusivamente a los animales, lo consignado en la Ley 1774 de 2016, artículo 3 (Corte Suprema de Justicia de Colombia, AHC4806-2017, 2017, núm. 2.4.5.1); y (iii) asume que la condición de cosa de los animales, implica que no se les reconoce su calidad de seres vivos sintientes y que esto lleva a su utilización indebida e incluso a su abuso. Se diferencia el pronunciamiento al no reconocer una modificación a las categorías del Código Civil” (2018, pág. 98).

Con todo, se observa un razonamiento antropocéntrico por parte de la Corte Suprema, cuando dispone que "El fin jurídico, ético y político es la necesidad improrrogable de crear una fuerte conciencia para proteger el entorno vital para la sobrevivencia del hombre, de conservación del medio ambiente y como lucha una frontal contra la irracionalidad en la relación hombre-naturaleza. Es un esfuerzo por la sensibilización con el medio ambiente, para buscar políticas públicas nacionales, mundiales e institucionales para amilanar toda forma de discriminación y de destrucción del ecosistema y del futuro de la humanidad."

\section{Sentencia STL 12651-2017 - Corte Suprema de Justicia de Colombia. Sala de Casación Laboral.}

La segunda sentencia referente a este caso, proferida también por la Corte Suprema de Justicia, fue resuelta por la Sala Laboral de dicha corporación, en fallo del 16 de agosto de 2017. Esta decisión se dio como resultado de una acción de tutela que fue interpuesta por la Fundación Botánica y Zoológica de Barranquilla contra la decisión de la Sala Civil de la Corte Suprema de Justicia anteriormente expuesta. Cabe señalar, que la acción de tutela es una acción de protección de los derechos fundamentales que tiene carácter expedito y excepcional, contemplada en el ordenamiento jurídico colombiano.

Esta acción se fundamentó en que, según el accionante, el fallo de la Sala Civil "produjo un impacto negativo en la sociedad generando un equivocado entendimiento constitucional y legal para el uso de las acciones legales" ${ }^{88}$, por lo que se solicitó que se dejara sin efecto la misma, por cuanto se constituía una vía de hecho. En ese sentido, la Sala Laboral plantea como problema jurídico, el siguiente: "sobre la posibilidad de agenciar derechos de un ser sintiente [...], para estudiar si, en efecto, existía legitimación y si, era viable acudir al Hábeas Corpus para su definición" $"$, cuestiones que resuelve de manera negativa.

A continuación, como señalan Murcia \& Molano, la Corte realiza dos aclaraciones relevantes, primero, que "de la calidad de persona se deriva la condición de ser sujeto de derecho" y, segundo, que en el ordenamiento jurídico colombiano los animales se encuentran dentro de una "categoría intermedia entre sujeto y objeto de derecho", en lo que, además, señalan las autoras, se asemeja a lo señalado por la sentencia

\footnotetext{
${ }^{86}$ Corte Suprema de Justicia de Colombia, AHC4806- 2017, 2017, 2.4.3 y 2.4.4.

${ }^{87}$ Corte Suprema de Justicia de Colombia, AHC4806- 2017, 2017, 2.4.5.3.

${ }^{88}$ Corte Suprema de Justicia de Colombia, STL12651-2017, 2017, I. Antecedentes.

${ }^{89}$ Corte Suprema de Justicia de Colombia, STL12651-2017, 2017, 4. Caso concreto.
} 
argentina de 2015 en la medida en que "La categoría de ser sintiente sí es una categoría nueva que no coincide con la de persona ni con la de cosa". 90

De nuevo, sobre el problema jurídico respecto de la concesión del habeas corpus a un animal, las autoras señalan que "la Corte considera que este derecho fundamental [habeas corpus] les corresponde de manera exclusiva a los individuos, no a cualquier entidad considerada como persona jurídicamente. La Sala Laboral utiliza la misma estrategia que usó la Sala Civil: extiende la noción de la persona jurídica, pero lo hace para mostrar que si a las primeras no se les puede conceder el derecho de habeas corpus por la forma en la que funcionan, a los animales tampoco se les puede conceder por la misma razón (cfr. STL 12651-2017, p.14). Más aún, teniendo en cuenta que a los animales no se les reconoce la calidad de personas"91

Así mismo, considera esta sala que de la calidad de sintiencia no se deriva o extrae la calidad de sujetos de derecho, como había señalado la Sala Civil, "sino que de tal calidad se derivan deberes de protección y tutela a cargo de las personas. A diferencia de la sentencia argentina de 2015, que consideraba que estos deberes de cuidado generaban un derecho en cabeza del objeto"92. Así, la sala concluye que para la protección de los animales basta con ejercer las acciones populares (acciones constitucionales para la "protección de los derechos e intereses colectivos, relacionados con el patrimonio, el espacio, la seguridad y la salubridad públicos, la moral administrativa, el ambiente, la libre competencia económica y otros de similar naturaleza"93) o aquellas acciones legales que contempla la Ley 1774 de 2016, y concluye que la Sala Civil incurrió en un defecto sustantivo, en la medida que su decisión tuvo como fundamento normas que no resultaban aplicables al caso, "al punto que reconocieron efectos distintos a los expresamente señalados por el legislador y, de contera, en defecto procedimental absoluto, pues desconocieron las formas propias de cada juicio, como quiera que otorgaron un trámite que es completamente ajeno al que corresponde, lo que al final provocó la vulneración al debido proceso de la Fundación Botánica y Zoológica de Barranquilla"94, motivo por cual esta Sala tomó la decisión de conceder el amparo al debido proceso y, por tanto, "dejar sin efecto la actuación surtida al interior de la acción constitucional de habeas corpus" ${ }^{95}$ resuelta por la Sala Civil.

\section{Sentencia STP16597-2017 - Corte Suprema de Justicia de Colombia. Sala de Casación Penal}

La sentencia expuesta anteriormente, proferida por la Sala de Casación Laboral de la Corte Suprema de Justicia, fue impugnada, y conoció del tema en segunda instancia la Sala Penal de esta misma Corte, la cual confirmó el fallo anterior. Dentro de los elementos que pueden resaltarse en el desarrollo de esta sentencia encontramos los siguientes:

1. La institución del Habeas Corpus es predicable exclusivamente de los seres humanos, con el fin de "Salvaguardar los derechos de un individuo privado de su locomoción o que creyera estarlo de manera ilegal" 96

2. "El Habeas Corpus es considerada como una garantía intangible, imprescriptible, inalienable e inviolable, atendiendo su carácter perentorio y de inmediata aplicación, que ha sido creada en virtud de la sensibilidad que representa el derecho fundamental a la libertad de un ser humano ante cualquier aprehensión y/o retención irregular"97 (Negrita fuera del texto).

3. La Corte Suprema, en este caso, acude a lo señalado por la Corte Constitucional en la sentencia C187 de 2006, en la cual se señala que "El radio de protección del habeas corpus no se limita a cubrir solo el derecho a la libertad sino que se expande para cubrir los otros derechos fundamentales intimamente relacionados con este, y que le dan soporte, como son los derechos a la vida y a la integridad personal" 98 (Negrita fuera del texto).

4. El reconocimiento del estatus de seres sintientes no implica el reconocimiento de derechos en cabeza de los animales, sino que de este se extrae un "deber constitucional de salvaguarda del bienestar

\footnotetext{
${ }^{90}$ MOLANO. A \& MURCIA, D. Animales y naturaleza como nuevos sujetos de derecho: un estudio de las decisiones judiciales más relevantes en Colombia (Bogotá 2018) 98.

${ }^{91}$ MOLANO. A \& MURCIA, D. Animales y naturaleza como nuevos sujetos de derecho: un estudio de las decisiones judiciales más relevantes en Colombia (Bogotá 2018) 99.

${ }^{92}$ MOLANO. A \& MURCIA, D. Animales y naturaleza como nuevos sujetos de derecho: un estudio de las decisiones judiciales más relevantes en Colombia (Bogotá 2018) 100.

${ }^{93}$ Constitución Política de Colombia. Artículo 88

${ }^{94}$ Corte Suprema de Justicia de Colombia, STL12651-2017, 2017, 4. Caso concreto.

${ }^{95}$ Corte Suprema de Justicia de Colombia, STL12651-2017, 2017, Resuelve.

${ }^{96}$ Corte Suprema de Justicia de Colombia, STP16597-2017, 2017, b. cuestión de fondo.

${ }^{97}$ Corte Suprema de Justicia de Colombia, STP16597-2017, 2017, b. cuestión de fondo.

${ }^{98}$ Corte Suprema de Justicia de Colombia, STP16597-2017, 2017, b. cuestión de fondo.
} 
animal que encuentra su fundamento igualmente del principio de la solidaridad, (...) lo anterior confirma la obligación superior de garantizar la integralidad de los animales, sin que, en ningún caso, dicho compromiso sea absoluto, ya que el mismo admite excepciones" predica frente al padecimiento, maltrato y crueldad, pero, se enfatiza, es un deber u obligación (la Corte utiliza ambos términos, al parecer de forma indistinta) de los humanos frente a los demás animales, pero no se puede entender que existe un "derecho al bienestar animal, fundamental, ni mucho menos la exigibilidad del mismo por medio de acciones constitucionales". ${ }^{100}$

5. Se reconoce que los animales tienen un estatus moral.

Esos son, a mi juicio, los elementos de mayor relevancia que pueden extraerse de la argumentación que hace la Corte Suprema de Justicia en este caso, antes de señalar que el habeas corpus no es una acción viable para proteger los derechos de un ser "no humano", ya que, aunque haya un deber de protección al bienestar animal, ello no quiere decir que exista una garantía fundamental en cabeza de los animales. ${ }^{101}$

En la parte resolutiva de la sentencia, hay otro aparte que creo merece una consideración especial, y es que la Sala Penal señala que "los actuales pensamientos propugnados por legislaciones internacionales conciben la posibilidad de que se extiendan los derechos de los seres humanos a los animales, como fue considerado en la determinación demandada, el ordenamiento jurídico nacional ha establecido que el Habeas Corpus únicamente puede ser invocados por una persona" ${ }^{102}$. Considero que este aparte es digno de un análisis adicional porque, más allá de que la acción de habeas corpus esté consagrada para proteger los derechos de las personas (entiéndase acá, seres humanos), es importante ver cómo se entiende que la libertad es un derecho propio de los humanos, por cuanto la sentencia habla de la extensión de los derechos de los seres humanos a los animales, pero, entonces, ¿no tienen acaso los animales no humanos derecho a la libertad? La discusión de fondo, creo, no debería ser si el habeas corpus es o no la acción adecuada, sino si los animales tienen o no derecho a la libertad, y creo que la respuesta debería ser afirmativa. Una vez dilucidado ese punto podría entrarse a discutir el mecanismo por el cual se debe garantizar este derecho.

\section{Sentencia SU-016 de 2020 - Corte Constitucional.}

La anterior sentencia (por tratarse de una sentencia de tutela) fue revisada por la Corte Constitucional, en un trámite en el cual se seleccionan los fallos de tutela de mayor relevancia según criterios objetivos, subjetivos y complementarios ${ }^{103}$, para que la Corte Constitucional emita una sentencia de revisión, trámite que culminó en la sentencia SU-016 de 2020, en la que se confirmó el fallo proferido en tutela por la Corte Suprema de Justicia.

Hasta el momento en que escribo este texto, no se ha publicado aún la sentencia, sino solo el comunicado de prensa, de modo que únicamente se tiene acceso a este documento, el cual señala a grandes rasgos lo que se dice en la sentencia, por lo que no es posible tener certeza de los términos exactos del fallo. En dicho comunicado se señala, en su encabezado, que "La Corte Constitucional determinó que el recurso de habeas corpus no es el mecanismo para resolver la controversia planteada en relación con la permanencia del oso andino Chucho en un zoológico, en la medida en que se trata de un instrumento de protección de la libertad de los seres humanos, que es un derecho que no se puede predicar de los animales" 104.

Grosso modo, el comunicado señala que la Corte Constitucional encuentra, como ocurrió en las dos sentencias expedidas por la Corte Suprema de Justicia en el trámite de tutela por la Sala Laboral y la Sala Penal, que el habeas corpus no es procedente para abordar la controversia planteada con relación al oso Chucho, por cuanto la naturaleza de dicha acción es la defensa de la libertad de la persona humana y, "en vista de su estructura procesal, de las instancias encargadas de resolverlo, y de su carácter sumarial" 105 , no constituía un mecanismo apto para resolver de este asunto. Ahora bien, salta a la vista en un primer momento, al leer el encabezado del comunicado, citado anteriormente, que la libertad no es un derecho que se pueda predicar de los animales, lo cual es preocupante en la medida que una cosa es que el mecanismo de habeas corpus no sea el adecuado para pedir la libertad de los animales, y otra que ese derecho no sea predicable de ellos.

\footnotetext{
${ }^{99}$ Corte Suprema de Justicia de Colombia, STP16597-2017, 2017, b. cuestión de fondo. Los animales como seres sintientes.

${ }^{100}$ Corte Suprema de Justicia de Colombia, STP16597-2017, 2017, b. cuestión de fondo. Los animales como seres sintientes.

${ }^{101}$ Corte Suprema de Justicia de Colombia, STP16597-2017, 2017, Caso Concreto.

${ }^{102}$ Sentencia STP16597-2017, Sala de Casación Penal, Corte Suprema de Justicia de Colombia.

${ }^{103}$ Artículo 52 del Reglamento Interno de la Corte Constitucional.

${ }^{104}$ Comunicado No. 03, 23 de enero de 2020. Corte Constitucional de Colombia.

${ }^{105}$ Comunicado No. 03, 23 de enero de 2020. Corte Constitucional de Colombia.
} 
En este caso no es posible profundizar mucho en las consideraciones de la Corte Constitucional en la medida en que el comunicado es muy breve. Sin embargo, es importante revisar algunas de las consideraciones hechas en los salvamentos de voto (de lo que se observa en el comunicado, se trata de una sentencia en la que hay mucha divergencia de posiciones, en la medida en que hay numerosos salvamentos y aclaraciones de voto).

Se señala que la magistrada Diana Fajardo Rivera salvó su voto, "porque en su concepto, la protección del Oso Chucho bajo la Constitución Política implica reconocerlo como titular de derechos, y específicamente, de la libertad animal"106, y así mismo, consideraba que el uso del habeas corpus en este caso, no era irrazonable. A continuación, señalo los puntos que considero más relevantes del salvamento de voto (según se describen en el comunicado):

1. La magistrada opina que la Sala debía preguntarse si era razonable considerar al oso Chucho como "destinatario de un bien llamado libertad"107, para lo cual, inevitablemente, se debía primero responder la pregunta ¿son los animales titulares de derechos? Esto coincide con lo que señalé anteriormente, en la medida en que la pregunta no debe simplemente limitarse a los aspectos formales, sino que se debe ir más allá y analizar si los animales no humanos son, o pueden ser, titulares de derechos, particularmente teniendo presente su reconocimiento como seres sintientes.

2. Los animales son titulares de derechos. La magistrada señala que hay una serie de elementos, como los avances jurisprudenciales creados a partir del reconocimiento de la sintiencia de los animales y de su valor intrínseco, los avances legislativos, las experiencias de derecho comparado (se mencionan los casos de Sandra y Cecilia en Argentina, citados acá previamente), y aportaciones de índole teórica, filosófica y científica que "dan cuenta, por un lado, de que las categorías jurídicas deben permitir comprender y dar respuesta a verdaderos problemas constitucionales, como el trato que debemos a los animales". ${ }^{108}$ Con relación a este punto, concuerdo en la medida en que considero que el desarrollo científico ha llevado a un punto en que no se pone en tela de juicio la calidad de seres sintientes de determinados animales no humanos, lo que conlleva necesariamente a que los mismos tengan una consideración moral y, por tanto, deban tener derechos, y el derecho -el ámbito jurídico- debe ajustarse a las nuevas realidades (que no son, en realidad, nuevas, sino que apenas se están determinando científicamente $\mathrm{y}$, por tanto, están permeando la mentalidad de los seres humanos), reconocer derechos a los seres sintientes y, en concordancia con ello, crear los mecanismos aptos para que se respeten dichos derechos.

3. Existe el derecho a la libertad animal. Se señala en el comunicado que la magistrada sostiene que el oso Chucho "es titular del derecho a la libertad animal, entendida como aquellas condiciones en las que se le permita expresar de mejor manera sus patrones vitales de comportamiento" ${ }^{109}$. Este es un planteamiento interesante, en cuanto a la posibilidad de delimitar lo que podría llegar a considerarse el derecho a la libertad animal. Considero que el punto de las delimitaciones es muy importante en el mundo del derecho animal, en la medida en que precisamente las delimitaciones o definiciones jurídicas se convierten en obstáculos, en formalidades que no permiten avanzar hacia la configuración de los derechos animales. Por supuesto, no se puede pretender que se desnaturalicen otras figuras jurídicas so pretexto de proteger a los animales, puesto que el mundo del derecho sin formalidades y definiciones no es concebible, pero este tipo de problemas lo vemos, por ejemplo, en temas como el de si se puede considerar a los animales sujetos de derecho, o personas (conceptos que incluso son a veces, como ya se indicó, utilizados como sinónimos en algunos ordenamientos).

4. El habeas corpus era el recurso adecuado para proteger el interés del oso Chucho. En la medida en que el ordenamiento jurídico colombiano no prevé expresamente una solución para el asunto en cuestión, considera la magistrada que este ordenamiento "sí contiene mandatos que permiten un acercamiento constitucional, con miras a que la función pública de administrar justicia se satisfaga. Por lo tanto, la solución a este tipo de asuntos novedosos exige el análisis de vías que actúen "como si" pudieran extenderse a estos nuevos escenarios". ${ }^{110}$ Sobre este punto, considero que si bien desde el punto de vista de la protección de los derechos de los animales es deseable que se hagan este tipo de aplicaciones análogas o extensivas de mecanismos jurídicos, ello puede conllevar, a la larga, a situaciones jurídicas indeseables, e incluso a problemas de indeterminación o inseguridad jurídica, por cuanto esto puede llevar a que haya abusos en el uso de mecanismos jurídicos y una extrema

\footnotetext{
106 Comunicado No. 03, 23 de enero de 2020. Corte Constitucional de Colombia.

${ }^{107}$ Comunicado No. 03, 23 de enero de 2020. Corte Constitucional de Colombia.

108 Comunicado No. 03, 23 de enero de 2020. Corte Constitucional de Colombia.

${ }^{109}$ Comunicado No. 03, 23 de enero de 2020. Corte Constitucional de Colombia.

110 Comunicado No. 03, 23 de enero de 2020. Corte Constitucional de Colombia.
} 
flexibilización por parte de los funcionarios judiciales que resuelvan los casos, que lleven completamente a que se desnaturalicen ciertos mecanismos, generando efectos adversos, como creo que ha sucedido ya en Colombia con la acción de tutela, precisamente.

5. La acción popular no es el mecanismo adecuado para solicitar la protección de los derechos del oso Chucho, en la medida en que dicha acción tiene por objeto "proteger el medio ambiente, como bien de titularidad colectiva. Bajo este parámetro, no es evidente que la situación de un animal -de su libertad- sea un asunto que repercuta de tal manera en el medio ambiente que logre su afectación y, por esta vía, convierta a un solo animal en objeto de protección, a través de dicho mecanismo y en beneficio de toda la comunidad"111. Opino que esta consideración es relevante en la medida en que si bien es cierto que el habeas corpus no es formalmente el mecanismo llamado a resolver una situación como la presente, por los motivos que se han señalado anteriormente, lo cierto es que la acción popular, en estricto sentido, tampoco lo es, precisamente porque es una acción encaminada a la protección de los intereses colectivos (del ser humano, naturalmente) y, en este caso, no se observa cómo el interés de un animal, de un único individuo pueda llegar a representar derechos e intereses colectivos. Por supuesto, comprendo que es posible lograr una argumentación mediante la cual se sostenga que este individuo puede tener un impacto ambiental, y que los animales son parte del medio ambiente (que es uno de los temas con relación a los cuales pueden protegerse derechos colectivos mediante este mecanismo), pero esto es, en todo caso, una suerte de extensión o adaptación de la acción popular para poder aplicarla a los animales, en casos que, en principio, no parecen estar dentro del marco de cobertura de la norma, por lo que cabría considerar la creación de medios que permitan la protección de un animal sin que tenga que hacerse por extensión del medio ambiente, sino en virtud de los intereses propios de ese individuo.

6. No equipara humanos a animales. Se señala en el comunicado que "la Magistrada Fajardo no equiparó las personas humanas a los animales; no sostuvo que fuera la dignidad la justificación de los intereses jurídicamente protegidos, como derechos, de los animales; tampoco estimó que los derechos de los animales fueran fundamentales, ni que las dimensiones de la libertad propias de los animales tuvieran los mismos alcances del derecho a la libertad de las personas; no sostuvo que exista un interés a la libertad animal de todas y cada una de las especies existentes sobre el planeta; tampoco sugirió que se pueda establecer por el Juez, en una especie de lista, qué intereses deben adscribirse a los animales."

Este es un punto muy importante, que debe aclararse de modo general por cuanto parece ser un aspecto que genera mucha resistencia por los detractores de declarar que los animales tienen derechos. No se pretende que se declare que los animales no humanos son iguales a los humanos en todo sentido, o que tienen los mismos intereses y derechos, esto sería absurdo. La cuestión es que hay intereses que se sabe que tienen ciertos animales, y son estos intereses los que se pretende que sean protegidos, y la forma de que estos encuentren una protección real es que se reconozcan como derechos.

En línea con lo anterior, se encuentra también lo señalado por el Magistrado Alberto Rojas, quien salvó parcialmente su voto y que, según el comunicado, señaló que "un animal no humano de cuya naturaleza se derivan derechos como (i) no tener hambre, sed, ni malnutrición; (ii) no tener miedo ni angustia; (iii) no padecer molestias físicas; (iv) no ser sometido a daños, lesiones o enfermedades; (v) libertad para expresar sus patrones naturales de comportamiento, puede tener una categoría jurídica de persona, que tiene sustrato en que se trata de seres sintientes y que se encuentran en un punto intermedio entre sujetos y objetos del derecho, como lo ha reconocido el propio legislador. Siendo ello así, la discusión debió centrarse en determinar qué tipo de garantías ostentan y cuales son los mecanismos de representación y de vindicación de las mismas, en un plano neoconstitucional que trascienda el antropocentrismo para llegar finalmente al biocentrismo." 113

\subsubsection{Sentencia C-045 de 2019 - Corte Constitucional.}

Este fallo tuvo lugar con motivo de una acción de inconstitucionalidad que fue interpuesta por una ciudadana en contra de los artículos 248, 252 y 256 del Decreto Ley 2811 de 1974 (Código Nacional de Recursos Naturales Renovables y de Protección al Medio Ambiente) y los artículo 8 y 30 de la Ley 84 de 1989 (Estatuto Nacional de Protección de los Animales).

${ }^{111}$ Comunicado No. 03, 23 de enero de 2020. Corte Constitucional de Colombia.

${ }^{112}$ Comunicado No. 03, 23 de enero de 2020. Corte Constitucional de Colombia.

${ }^{113}$ Comunicado No. 03, 23 de enero de 2020. Corte Constitucional de Colombia. 
El artículo $8^{\circ}$ de la Ley 84 de 1989 determinaba una serie de actividades que se consideraban como exceptuadas de lo dispuesto en lo dispuesto en el artículo $6^{\circ}$ de esta norma, es decir, que las excluia de la consideración de "hechos dañinos y actos de crueldad para con los animales" 114 , conductas que conforme a esta norma eran sancionadas. Dentro de estas conductas exceptuadas por el artículo $8^{\circ}$ se encontraban "los actos de aprehensión o apoderamiento en la caza y pesca deportiva, comercial, industrial, de subsistencia o de control de animales silvestres, bravíos o salvajes". Por otro lado, el artículo 30 de la Ley 84 de 1989 indicaba que "La caza de animales silvestres, bravíos o salvajes está prohibida en todo el territorio nacional, pero se permitirá en los siguientes casos:[...] b) Con fines científicos o investigativos, de control, deportivos, educativos, de fomento, pero con autorización previa, escrita, particular, expresa y determinada en cuanto a zona de aprehensión, cantidad, tamaño y especie de los ejemplares, duración del permiso y medios de captura, expedida por la entidad administradora de los recursos naturales". (Subrayado en el texto original de la sentencia. Los apartes subrayados son los que fueron objeto de la acción de inconstitucionaldad).

La Corte Constitucional en su estudio consideró que "aun aceptando la hipótesis de que la caza no genera mutilación ni sufrimiento, sí puede consistir en darle muerte al animal. El sacrificio de la vida de un ser vivo por el hombre es una forma extrema de maltrato en cuanto elimina su existencia misma y es un acto de aniquilamiento. Cuando es injustificada, la muerte de un animal es un acto de crueldad pues supone entender que el animal es exclusivamente un recurso disponible para el ser humano. La caza deportiva, en fin, es un acto dañino en cuanto está dirigida a la captura de animales silvestres, ya sea dándoles muerte, mutilándolos o atrapándolos vivos."

Como indiqué anteriormente, en Colombia se permite el maltrato animal en determinadas ocasiones y bajo ciertas circunstancias, de conformidad con la jurisprudencia de esta misma Corte. Al respecto, en esta oportunidad, la Corte Constitucional señaló que:

la caza deportiva no satisface ningún objetivo ni finalidad compatible con la Constitución. Resta por analizar si la caza deportiva es expresión de una cultura arraigada en Colombia que deba ser objeto de protección constitucional, o si está amparada por normas internacionales que prevalezcan en el orden interno.

\section{$[\ldots]$}

Se concluye entonces que la caza deportiva no encuentra fundamento en ninguna de las excepciones reconocidas jurisprudencialmente a la prohibición del maltrato animal. La caza deportiva no es expresión de la libertad religiosa, no tiene como objetivo la alimentación, ni la experimentación médica o científica; tampoco el control de las especies; ni se trata de una manifestación cultural arraigada. Por consiguiente, la Corte no encuentra necesario aplicar los criterios de razonabilidad o proporcionalidad, pues ni siquiera existe una de las excepciones que darían lugar al análisis sobre lo que debe primar, por ejemplo, la protección de una práctica cultural o religiosa, o la prohibición del maltrato animal.

Por lo anterior, la Corte resolvió declarar inexequibles las normas demandadas del Decreto Ley 2811 de 1974 y de la Ley 84 de 1989, salvo el artículo $8^{\circ}$ de esta última, que fue declarado exequible bajo el entendido de que la caza deportiva no constituye una excepción a lo dispuesto en los literales a), c), d) y f) del artículo $6^{\circ}$ de la misma ley, con lo que, para los efectos prácticos, constituye una prohibición de la caza con fines deportivos.

Esta sentencia evidencia una tendencia a la limitación y reducción de los supuestos en los que se considera que se puede justificar el maltrato animal en Colombia, incluso pudiendo llegar a limitar, como en este caso, algunos derechos de seres humanos, como podría ser el del libre desarrollo de la personalidad, poniendo por encima de estos, el interés de los animales no humanos, lo que es lógico, puesto que la libertad de un ser humano de desarrollarse libremente no puede tomarse como una justificación para la violación de los intereses de otros seres, en especial la vida. Al respecto, vale la pena resaltar que Corte Constitucional señala que "la prohibición del maltrato animal constituye una limitación a los derechos a la cultura, a la recreación, al deporte, a la educación, al libre desarrollo de la personalidad y a la libre iniciativa privada".

\subsubsection{El caso del perro Clifor. Sentencia del Juzgado Primero Penal del Circuito con funciones de conocimiento, del 26 de junio de 2020.}

${ }^{114}$ Ley 84 de 1989. Artículo 6 
Luego de que la Corte Constitucional profiriera la sentencia SU-016 de 2020, este caso ha hecho resurgir el debate sobre los derechos de los animales en Colombia. Clifor es un perro que sufre de epilepsia idiopática, motivo por el cual se le recetó el medicamento fenobarbital, que -según se manifiesta en la sentencia- es el único medio por el cual se puede tratar dicha enfermedad en perros. Este medicamento era suministrado en la ciudad de Ibagué por la Gobernación del Tolima, que era la única entidad autorizada por el Ministerio de Salud para ello, con fórmula médica. En febrero de 2020, los responsables del perro (su familia), compraron en la Gobernación del Tolima 60 pastillas del mencionado medicamento, el cual duró aproximadamente tres meses. El 30 de mayo el veterinario recetó nuevamente 60 pastillas, por lo que la familia del perro se dirigió a la Gobernación para comprar el medicamento, pero les indicaron que no había atención al público, por lo que no fue posible comprarlo. Así, nuevamente, el 8 de junio intentaron comprar el medicamento, y recibieron la misma respuesta, por lo que intentaron comprarlo en farmacias veterinarias en la ciudad de Ibagué y en otras ciudades y ello no fue posible, motivo por el cual la señora Lina Sofía Lozano instauró una acción de tutela solicitando que se ordenara al Departamento del Tolima, al Ministerio de Salud, al Ministerio de Ambiente y Desarrollo Sostenible, entre otras entidades, que se tomaran las medidas necesarias para que la señora Lozano Cárdenas pudiera adquirir el medicamento Fenobarbital.

El juzgado que conoció del caso, se basó en lo señalado en la Ley 1774 de 2016, así como en la sentencia C-041 de 2017, en la que, como ya señalamos, se indicaba que "[a]unque la Constitución no reconozca explícitamente a los animales como titulares de derechos, ello no debe entenderse como su negación" y señaló que "el hombre [debió referirse a los humanos] es uno más de los seres vivos que habitan este planeta y que al igual que él, los demás seres que ostentan vida tienen derecho a que se les reconozcan prerrogativas, pues estas no son exclusivas de los seres humanos", y resaltó que, de conformidad con la ley y la jurisprudencia colombiana, los animales son seres sintientes y que, como tal, y de acuerdo con el principio de solidaridad social, el Estado y la sociedad tienen la obligación de "asistir y proteger a los animales con acciones diligentes ante situaciones que pongan en peligro su vida, su salud o su integridad física". Así mismo, este juzgado acudió a la jurisprudencia de la Corte Constitucional, para señalar que no hay un concepto único y excluyente de familia, de modo que no es posible limitar este concepto a aquellas conformadas en virtud de vínculos jurídicos o biológicos, sino que debe extenderse a las "relaciones de hecho que surgen a partir de la convivencia y que se fundan en el afecto, el respeto, la protección, la ayuda mutua, la comprensión y la solidaridad" 115 , de modo que no puede entenderse a la familia -núcleo básico de la sociedad- como un concepto monolítico, sino dinámico y cambiante.

Lo anterior es interesante por cuanto parte de la decisión se funda en la inclusión del animal no humano como miembro de la familia, así, se indica en la sentencia que si un animal necesita un servicio de salud y este le es negado, ello constituye una vulneración del deber de protección de los animales (que compete a la familia de aquel, a la sociedad y al Estado) y que es una situación contraria al principio de solidaridad social que le es exigible como forma de garantizarle una mejor calidad de vida a los individuos, a las comunidades y a los seres sintientes. Por eso, concluyó el juzgado, que se afectó el derecho del núcleo familiar a obtener de forma oportuna el medicamento que se requiere para poder garantizar la supervivencia de Clifor.

Así, se expresó en la sentencia que la entidad responsable de garantizar la disponibilidad del medicamento en la jurisdicción en cuestión, no estaba cumpliendo con ello, lo cual se traducía en la imposibilidad de otorgar efectivamente a Clifor el acceso al tratamiento requerido para asegurar su salud y supervivencia y, por lo tanto, señaló el juzgado, el Estado incumplió con su deber de realizar "acciones diligentes en procura de garantizar su salud y su integridad física, teniendo la obligación de garantizar la disponibilidad del medicamento solicitado". Por lo tanto, el juzgado consideró que lo anterior vulneraba los derechos fundamentales a la preservación de la unidad familiar de la señora Lina Sofía Lozano, al poner en riesgo a Clifor, quien, como se señala en la sentencia, es parte de la familia, habida cuenta del apego emocional, y considerando el concepto de familia multi-especie. Por supuesto, el juzgado señaló también que esta situación violaba el derecho que tenía Clifor de acceder al suministro del medicamento ordenado por el médico veterinario, en la medida en que la falta de acceso al mismo afectaba su expectativa de vida e implicaba un grave riesgo a su salud e, incluso, a su vida.

La sentencia señaló que la omisión de trámites administrativos internos por parte de las entidades encargadas de garantizar el suministro de este medicamento no eran justificación suficiente, y recordó que dado que se trataba de un medicamento cuyo monopolio de distribución correspondía al Estado, era obligación de este facilitar los medios para garantizar el acceso al mismo. Por ello también declaró que la Secretaría de Salud del Tolima y el Fondo Rotatorio del Tolima violaron los derechos a la preservación del núcleo familiar de la señora Lozano Cárdenas y el derecho a la "supervivencia del ser sintiente Clifor", por lo que ordenó a las mencionadas entidades que, en el término de 48 horas siguientes a la decisión judicial, realizaran las

${ }^{115}$ Corte Constitucional de Colombia, Sentencia C-026 de 2016.

140 Derecho Animal. Forum of Animal Law Studies, vol. 12/3 
gestiones "para la adquisición y/o suministro del medicamento "FENOBARBITAL", para que en ese lapso, se tenga a disposición de este y le sea suministrado a la señora LINA SOFÍA LOZANO CÁRDENAS, propietaria del ser sintiente con nombre Clifor".

\subsection{Corte Interamericana de Derechos Humanos. Opinión Consultiva OC-23-17 de 15 de noviembre de 2017.}

La discusión sobre la protección y reconocimiento de los animales no solo se encuentra presente en el ámbito jurídico de los Estados individualmente considerados, sino que además ha ido tomando lugar en el plano internacional, como ocurre, por ejemplo, en la Unión Europea, y también pueden encontrarse pronunciamientos de índole supra nacional en los que se hace aborda este tema.

Esta opinión consultiva tiene lugar debido a una solicitud realizada por la República de Colombia a la Corte Interamericana de Derechos Humanos, frente a las "Obligaciones estatales en relación con el medio ambiente en el marco de la protección y la garantía de los derechos a la vida y a la integridad personal". Si bien en ella no se habla expresamente de un reconocimiento de derechos a los animales no humanos, o de un reconocimiento de estos como seres sintientes, se reconoce que son merecedores de protección en sí mismos, lo que se hace en los siguientes términos:

Esta Corte considera importante resaltar que el derecho al medio ambiente sano como derecho autónomo, a diferencia de otros derechos, protege los componentes del medio ambiente, tales como bosques, ríos, mares y otros, como intereses jurídicos en sí mismos, aún en ausencia de certeza o evidencia sobre el riesgo a las personas individuales. Se trata de proteger la naturaleza y el medio ambiente no solamente por su conexidad con una utilidad para el ser humano o por los efectos que su degradación podría causar en otros derechos de las personas, como la salud, la vida o la integridad personal, sino por su importancia para los demás organismos vivos con quienes se comparte el planeta, también merecedores de protección en sí mismos. En este sentido, la Corte advierte una tendencia a reconocer personería jurídica y, por ende, derechos a la naturaleza no solo en sentencias judiciales sino incluso en ordenamientos constitucionales ${ }^{116}$.

Lo anterior, es relevante principalmente: 1) Porque se reconoce que los animales (organismos vivos con quienes se comparte el planeta) son merecedores de protección en sí mismos, es decir, teniendo en cuenta sus intereses, y no como un medio para satisfacer intereses o buscar el bienestar de los humanos, o como parte de la naturaleza; 2) Porque muestra que el tema de los derechos de los animales, empieza a permear, también en el continente americano, en el plano internacional, de modo que las tendencias que se observan dentro de las legislaciones y la jurisprudencia latinoamericanas empieza a reflejarse en pronunciamientos de índole internacional.

\section{Necesidad de una categoría jurídica propia para los animales no humanos y la necesidad de tomarse la sintiencia en serio.}

Hemos visto cómo el reconocimiento de los animales como seres sintientes por la ciencia ha ido abriéndose campo también en el mundo jurídico y ha ido dando lugar a una serie de consideraciones en cuanto al estatus de los animales, consideraciones que, a su vez, han permitido que se vislumbre un cambio de paradigma en el cual ya no se considere a los animales como cosas. Sin embargo, aunque es clara la tendencia a reconocer que no son cosas, y ello a su turno ha llevado a que se les catalogue jurídicamente como seres sintientes, no es claro aún qué implica este reconocimiento. No es claro si este les confiere el estatus de personas, o de sujetos de derecho, o si están en el marco de una categoría intermedia entre objeto y sujeto. En cualquiera de estos casos, surgen una infinidad de dudas sobre qué implicaciones tendría la categorización de los animales dentro de alguna de estas figuras jurídicas, de modo que, en general, ha habido distintos pronunciamientos jurisprudenciales con diversas consideraciones que ofrecen soluciones puntuales a los casos que se plantean, pero que no ofrecen herramientas para resolver los cuestionamientos que surgen sobre las implicaciones del reconocimiento de la sintiencia de los animales a nivel jurídico.

Este tema merece seriedad en su resolución, por lo que no basta con que se vayan profiriendo fallos que solucionen de una u otra forma casos puntuales, sin un marco jurídico claro sobre el cual se sustenten estos, máxime porque ello da lugar a una serie de interpretaciones por parte de los jueces que pueden ser arbitrarias, por más que estos se empeñen en hacer un estudio juicioso sobre la sintiencia animal para proferir estos

\footnotetext{
${ }^{116}$ Corte Interamericana de Derechos Humanos. Opinión Consultiva OC-23-17 de 15 de noviembre de 2017 solicitada por la República de Colombia. 62.
} 
pronunciamientos. Es necesario que se le dé al tema la relevancia justa y se profieran leyes que tengan en cuenta aspectos etológicos y biológicos, que ofrezcan un marco jurídico sólido sobre el cual pueda la jurisprudencia desarrollar el ámbito del derecho animal, porque por lo pronto, parece que se hacen construcciones sin bases sólidas, lo cual difícilmente puede llevar a un buen resultado, aunque se tengan buenas intenciones.

Tiene que entenderse, además, que la sintiencia no es la única consideración que debe hacerse a la hora de definir a los animales jurídicamente. Aunque sea el elemento central a tener en cuenta para efectos del reconocimiento de derechos a los animales, como ya he mencionado, hay otros elementos que pueden o deben considerarse. Chapouthier señala que algunos animales muestran características comportamentales altamente complejas, al punto que pueden utilizar reglas semánticas, son conscientes de las características del ambiente en el que viven e, incluso, es probable que los más inteligentes hayan alcanzado ciertos niveles de consciencia de sí mismos como individuos; asimismo, hay animales que han desarrollado comportamientos culturales, que no se transmiten genéticamente, pero se enseñan entre ellos, como el uso de herramientas, comunicaciones relativamente sofisticadas, la habilidad de desarrollar lenguaje simple e incluso la creación de algunas reglas para la existencia armónica y la organización de la comunidad en la que viven, así como preferencias estéticas. Puesto que este tipo de capacidades intelectuales pueden llevar a una "autonomía comportamental" 117 , cada animal puede adoptar una serie de comportamientos independientes que considere apropiados diferentes a aquellos de otros miembros de su grupo. ${ }^{18}$

Este autor señala que este tipo de autonomía etológica o biológica ofrece una base para el enfoque filosófico de los derechos de los animales, y este enfoque debe, posteriormente, ser reflejado en la ley, de modo que los legisladores tengan en consideración la información y datos basados en conocimiento etológico a la hora de determinar los derechos que deben darse a ciertas especies, de modo que los derechos en general deberían ofrecer una protección a los animales sintientes para aliviar o evitar el sufrimiento y, por otro lado, deberían otorgarse otros derechos adicionales a animales que tengan mayores habilidades o capacidades intelectuales, con base en esas habilidades precisamente. ${ }^{119}$

En efecto, creo que es necesario que se establezcan derechos mínimos a los animales sintientes como tal, sin embargo, no creo que estos derechos deban limitarse a que se reduzca el sufrimiento de los animales como señalaba Chapouthier- y, por el contrario, considero que el reconocimiento de la sintiencia de los animales debe (acá hablo, por supuesto, desde el deber ser) implicar el reconocimiento de los derechos de los animales a la vida y a evitar completamente (no reducir) su sufrimiento.

Por otro lado, concuerdo con que además debería haber una suerte de derechos adicionales que se confieran a ciertos animales de acuerdo a sus características, pero no creo que los mismos deban reconocerse con base en las capacidades cognitivas o inteligencia de los animales, en la medida en que esto implica, de alguna forma, concederles mayor consideración moral en cuanto más similares sean al ser humano. Por ello creo que estos derechos adicionales deben determinarse teniendo en cuenta las características particulares de las especies, así como con base en la relación de los animales con los seres humanos.

Rey Pérez señala que hay animales que son capaces de aprender la moral como contenido, lo que implica que deben estar dotados de una estructura moral, y ello implica que los humanos compartimos con los animales no humanos la moral como estructura que nos permite asumir reglas y mandatos morales, pero que nos diferencia la ética, a saber, "la capacidad reflexiva y filosófica para analizar lo que eso significa, su sentido más o menos trascendente" ${ }^{120}$ Rey Pérez considera que el hecho de que los animales no tengan esta capacidad ética no debe ser motivo para excluirlos de la comunidad moral y que, por lo tanto, los animales no son solo pacientes morales sino agentes morales, y que, entonces, aunque tal vez sin comprender el porqué, entienden cuando no cumplen una norma moral y, por lo tanto, de alguna forma, pueden responder por ello.

Hago mención a esta idea, porque, al igual que con el planteamiento del reconocimiento de derechos de los animales según su inteligencia, la considero problemática, en la medida en que es posible que haya animales que sean sintientes, pero no sean capaces de "aprender la moral como contenido", en palabras de Rey Pérez, y, entonces, no puedan saber cuando no cumplen con una norma moral, y no creo que esto sea un motivo que pueda justificar su exclusión de la comunidad moral. Creo que el elemento que debe dar lugar a la inclusión de los animales en esta comunidad y, en esa medida, el reconocimiento de derechos morales que a su vez deberían, idealmente, alcanzar un reconocimiento jurídico, es la sintiencia.

Francione señala que no hay razón para sostener que las diferencias que puedan existir entre las mentes

\footnotetext{
117 "Behavioral autonomy".

${ }^{118}$ CHAPOUTHIER, G. From Animal Intelligence to Animal Rights. En FAVRE. D., \& GIMÉNEZ-CANDELA. T., Animales y Derecho (Valencia 2015) 148

${ }^{119}$ CHAPOUTHIER, G. From Animal Intelligence to Animal Rights. En FAVRE. D., \& GIMÉNEZ-CANDELA. T., Animales y Derecho (Valencia 2015) 148

${ }^{120}$ REY PÉREZ, J. L. Los Derechos de los Animales en Serio (Madrid 2018) 214

142 Derecho Animal. Forum of Animal Law Studies, vol. 12/3
} 
de los humanos y de los animales (no humanos) significan que estos no tengan interés en la continuidad de su existencia, o que las experiencias sintientes de los animales no humanos tengan un menor peso que aquellas de los humanos. Señala, además, que decir que un ser sintiente -cualquier ser sintiente- no se ve afectado o dañado por la muerte es, decididamente, extraño (odd), en la medida en que la sintiencia no es una característica que haya evolucionado para servir como un fin en sí misma, sino que se trata de un rasgo que permite a los seres que la tienen identificar situaciones que son dañinas para ellos o que amenazan su supervivencia. En ese sentido, la sintiencia es un medio para alcanzar un fin: la continuidad de la existencia. Los seres sintientes, por virtud de ser sintientes, tienen un interés en permanecer vivos, esto es, que prefieren, quieren o desean permanecer vivos. Por lo tanto, decir que un ser sintiente no se ve afectado por su muerte, niega que ese ser tiene el interés que es en sí el fin mismo de la sintiencia, el interés que esta busca perpetuar; en ese sentido, una situación análoga sería decir que un ser con ojos no tiene un interés en continuar viendo, o no se ve afectado por quedar ciego. ${ }^{121}$

Adicionalmente, Francione indica que la teoría de los derechos animales, como él la ha desarrollado, rechaza la noción de que algunos no-humanos, tal como los grandes simios, merezcan un mayor estatus moral o mayor protección legal que otros por el simple hecho de ser más parecidos a los seres humanos. En ese orden de ideas, explica, el hecho de que la mente de los humanos difiera de la de los no-humanos no significa que la vida de un humano tenga mayor valor moral, tal como la vida de un humano "normal" no tiene mayor valor moral que la vida de un humano con discapacidades mentales, o como la vida de un humano de mayor inteligencia no tiene mayor valor moral que la vida de un humano con una menor inteligencia. Aunque las diferencias entre humanos y otros animales pueden ser importantes en algunos sentidos, estas diferencias son completamente irrelevantes frente a la consideración moral del uso y maltrato de animales, aunque se haga de forma "humana" 122

De acuerdo con lo anteriormente señalado, y a modo de conclusión, considero que el reconocimiento de la sintiencia de los animales debe implicar el reconocimiento de los derechos de estos a la vida y a no sufrir maltrato ni físico, ni psicológico, en la medida en que, como explica Francione, la sintiencia es un medio por el cual los seres que la ostentan buscan la existencia continuada y, por lo tanto, el hecho de disponer de la vida de aquellos es contraria al reconocimiento que se les da como seres sintientes, sin importar los medios o forma por la cual se les mate. De modo que el tomarse en serio la sintiencia animal implica tomarse en serio el respeto por la vida de aquellos, ya que las diferencias existentes entre ellos y los humanos, si bien relevantes en algunos aspectos, no tienen relevancia alguna frente a la discriminación de por qué una vida vale más que otra.

El reconocimiento de los animales como seres sintientes, pues, debería conllevar el reconocimiento de esta categoría como una categoría jurídica en propiedad, dentro de la cual los seres que ostentan esta calidad sean titulares de derechos mínimos (¿fundamentales?) a la vida, a la libertad, a la dignidad y a la integridad, que deben ser reconocidos a cada ser sintiente como individuo, y que deben ser inviolables. Esta categoría, a su vez, serviría como base a partir de la cual se pueda dar un desarrollo jurídico -legislativo y jurisprudencialsólido al derecho animal, que deberá posteriormente llevar al reconocimiento de derechos especiales o adicionales a las distintas especies de animales de acuerdo con sus características particulares y sus necesidades, que no tendrá como base la inteligencia de los animales, por cuanto este reconocimiento de mayor valor moral según la inteligencia en parámetros humanos perpetúa la creencia de la superioridad o de mayor valor moral de los humanos. Como señala Pezzeta "el propósito moral de los derechos inviolables es proteger a aquellos seres que lo necesiten frente a posibles ataques o frente a discursos y prácticas que los instrumentalicen en aras de un bien mayor (en general, cualquier bien, por superfluo que sea, para los humanos)". ${ }^{123}$

La idea de derechos inviolables, como señalan Donaldson y Kymlicka ${ }^{124}$, implica que los intereses más básicos de un individuo no pueden ser sacrificados por el bien mayor de otros. Así, un humano no puede ser asesinado con el fin de recolectar sus órganos y otras partes del cuerpo, sin importar que docenas de otros seres humanos se puedan beneficiar de estas, ni puede ser utilizado para experimentación médica no consentida, sin importar el conocimiento que pueda ganarse de esa práctica. Por tanto, los derechos inviolables son una especie de círculo protector que se dibuja alrededor de un individuo, asegurando que no sea sacrificado para el bien de otros, y que suele entenderse en términos de derechos básicos negativos contra daños fundamentales como el asesinato, la tortura, la esclavitud o el confinamiento. La cuestión es determinar si los intereses básicos de alguien pueden o no ser sacrificados por el bien superior de otros, y para el caso de los

\footnotetext{
${ }^{121}$ FRANCIONE, G. Animal Welfare and the Moral Value of nonhuman Animals. Law, Culture and the Humanities (2010) 32

${ }^{122}$ FRANCIONE, G. Animal Welfare and the Moral Value of nonhuman Animals. Law, Culture and the Humanities (2010) 34

${ }^{123}$ PEZZETA, S. Una teoría del derecho para los animales no humanos. Aportes para la perspectiva interna del Derecho, en Revista Bioética y Derecho 44 (2018) 172

${ }^{124}$ DONALDSON, S., \& KYMLICKA, W. Zoopolis: A political theory of animal rights. (New York 2011) 19
} 
seres humanos (con relación a los derechos humanos), es claro que la respuesta es negativa. La propuesta es que esto mismo ocurra con relación a los animales no humanos, que se les reconozcan unos derechos mínimos inviolables que no puedan ser sacrificados en pro de intereses de otros.

Sue Donaldson y Will Kymlicka plantean en Zoopolis una teoría de los derechos animales amplia, en la que se integren unos derechos universales negativos (derecho a no ser privados de la vida, a no ser privados de la libertad, a no ser torturados...) debidos a todos los animales "con una experiencia subjetiva del mundo", pero en la que se incluyan derechos positivos diferenciados sujetos a (o dependientes de) la naturaleza de la relación humano-animal ${ }^{125}$. Lo anterior, lo hacen situando a los animales dentro de un marco explícitamente político, es decir, pasan el debate de los animales de un problema de ética aplicada a una cuestión de teoría política. Teniendo en cuenta este planteamiento, considero que es viable que los derechos adicionales o especiales a los que hice mención párrafos atrás, sean reconocidos también teniendo como fundamento las relaciones de los animales con los humanos, y no solo las características particulares y las necesidades de aquellos, de modo que puedan fijarse condiciones bajo las cuales haya interacciones entre humanos y animales que, como señalan Donaldson y Kymlicka, sean respetuosas, mutuamente beneficiosas y que no constituyan explotación de los animales ${ }^{126}$. Por supuesto, hay relaciones que considero no pueden encajar dentro de este supuesto, y que constituyen explotación per se, por lo que situaciones como el consumo de cuerpos o secreciones animales, $\mathrm{u}$ otras como el toreo, o las exhibiciones de los animales en circos, por mencionar algunos ejemplos, no pueden ser consideradas como interacciones respetuosas y mutuamente beneficiosas.

De acuerdo con algunas consideraciones hechas anteriormente, Nussbaum señala que la sintiencia no es lo único que importa para efectos de justicia básica, pero que parece plausible que la sintiencia sea la condición umbral para considerar a un ser como miembro de la comunidad de seres que tienen derechos o prerrogativas ("entitlements") basados en la justicia ${ }^{127}$. Así, lo que es relevante con relación al daño del dolor es la sintiencia, pero lo que es relevante frente al daño de una forma específica de dolor, es una forma específica de sintiencia (como, por ejemplo, la capacidad de imaginar la propia muerte), y en ese orden de ideas, las formas de vida más complejas, tienen capacidades más complejas que pueden ser arruinadas ("blighted") y, por lo tanto, pueden sufrir más y diferentes tipos de daño. En ese sentido, hay características ${ }^{128}$ que son relevantes no porque les den a algunas especies un valor diferente per se, sino porque el tipo y grado de daño que pueden sufrir puede variar según estas.

Ahora bien, el hecho de que se reconozca que los animales no humanos tienen derechos inviolables no quiere decir que se les reconozcan los mismos derechos que a los seres humanos. Como expresé anteriormente, deben reconocerse unos derechos básicos inviolables, y habrá otra serie de derechos que partan de las características particulares de las especies, así como de las relaciones de estos con los seres humanos, aunque, por supuesto, esto no implica que se les reconozcan los mismos derechos. Así, es claro que no se reconocerán a los animales derechos a la libertad religiosa, o el derecho al voto. Como señalan Donaldson y Kymlicka esto suele esgrimirse como una reducción al absurdo de la idea de los derechos animales, a lo que añaden que incluso dentro de los seres humanos tenemos derechos diferenciados, basados en nuestras capacidades y relaciones ${ }^{129}$. Así, por ejemplo, los ciudadanos tienen derechos que no tienen los visitantes de un territorio (voto, servicios sociales), los adultos tienen derechos que los niños y niñas no tienen, e incluso personas con ciertas capacidades racionales tienen derechos que no tienen aquellas con discapacidades mentales (como manejar sus propias finanzas).

De esta forma, no se debe entender que todos los animales (humanos y no humanos) deben tener los mismos derechos, sino que, como expresa Singer, la pertenencia a una especie en específico (en este caso a la humana) no puede ser la característica o el elemento que determine la inclusión de unos seres y la exclusión (total o parcial) del ámbito de protección moral. En ese sentido, cuando entendemos que, en lo que respecta a las características relevantes en este ámbito, no hay ninguna diferencia entre humanos y otros animales, es fácil ver que el pensamiento que sostiene que todos los humanos son -de algún modo- infinitamente más valiosos que cualquier otro animal, es un prejuicio. Esto, en algunos aspectos, es similar al prejuicio que tienen los racistas en favor de su propia raza, y los sexistas de su propio género; el especismo es, en un sentido lógico, paralelo al racismo y el sexismo, en cuanto los especistas, racistas y sexistas sostienen que el límite de su propio grupo es el límite de su consideración/preocupación ("concern"), y aunque los especistas favorezcan un grupo más amplio que los racistas y tengan, por tanto, un mayor círculo de consideración, todos estos

\footnotetext{
${ }^{125}$ DONALDSON, S., \& KYMLICKA, W. Zoopolis: A political theory of animal rights. (New York 2011)

${ }^{126}$ DONALDSON, S., \& KYMLICKA, W. Zoopolis: A political theory of animal rights. (New York 2011) 10

${ }^{127}$ NUSSBAUM, M. C. Beyond "Compassion and Humanity" Justice for Nonhuman Animals. En NUSSBAUM M. C. \& C. R. SUNSTEIN, Animal Rights: Current Debates and New Directions (Oxford 2012) 11

${ }^{128}$ La autora hace referencia a "level of life".

${ }^{129}$ DONALDSON, S., \& KYMLICKA, W. Zoopolis: A political theory of animal rights (New York 2011) 22
} 
prejuicios usan una característica arbitraria y moralmente irrelevante, como la pertenencia a una raza, el género o la especie, como si fueran moralmente relevantes. ${ }^{130}$

Por supuesto, estoy hablando desde lo que considero el deber ser, ya que es evidente, y no puede dejarse de lado, el hecho que este reconocimiento de los animales no humanos como sujetos titulares de derechos en propiedad tendría una basta gama de repercusiones en el mundo jurídico y en la sociedad, en general. Ellos afectarían intereses económicos, a los que suele dárseles mayor peso que a las consideraciones éticas o morales a la hora de legislar. Sin embargo, considero que es el punto al que se debe buscar llegar, la meta, si se quiere.

Creo que eventualmente se alcanzará esta meta, se llegará al punto en que el que los animales sean protegidos seriamente por la Ley, y en el que su carácter de seres sintientes sea respetado y se los valore como tal, un punto en el que se les reconocerá y respetará el derecho a la vida, y no se les tratará como simples objetos para explotación y beneficio del ser humano. Sin embargo, tengo claro que para llegar a este objetivo se debe recorrer un camino largo y con muchas dificultades, y que no es posible esperar lograr ese objetivo de la noche a la mañana, sino que deben ir dándose pasos en el sentido que se busca.

El profesor Heron J. de Santana Gordilho, por ejemplo, señala en su libro Animal Abolitionism. Habeas Corpus for Great Apes, que "en la posición gradualista o restriccionista las jaulas limpias de hoy serán las jaulas vacías de mañana, de modo que el uso retórico del lenguaje de derechos y la lucha por un objetivo abolicionista en el largo plazo, deben ser seguidos por agendas prácticas e ideológicas que aseguren el inmediato avance en la calidad de vida de los animales" ${ }^{131}$. En línea con lo que expresa el citado profesor sobre la postura restriccionista, considero que debe buscarse acabar con la explotación de los animales no humanos por parte de los seres humanos; sin embargo, creo que esto no es realizable de un momento a otro, y ni siquiera en el corto o mediano plazo, y por lo tanto es necesario que se adelanten reformas que mejoren las condiciones en que se encuentran los animales en el mundo $\mathrm{y}$, al mismo tiempo, vayan preparando el camino -y abriéndole los ojos a algunos humanos- con miras a una futura eliminación de la explotación animal. Sin embargo, es preciso anotar que mi posición dista de posturas abolicionistas, como la de Gary Francione, por cuanto considero que puede haber relaciones entre los humanos y los demás animales que no impliquen explotación y que no deban ser eliminadas necesariamente.

Aunque hay opiniones en contra de la postura de tomar medidas paulatinas, como que puede generar la idea en los humanos de que se están cumpliendo ciertos estándares y se están respetando los derechos de los animales aun cuando estos sigan siendo explotados y, por tanto, se podría incurrir en retrasar u obstaculizar el objetivo de la abolición de la explotación animal, concuerdo con Garner, en que rechazar la toma de medidas de protección o mejoramiento de las condiciones animales es algo también cuestionable moralmente, ya que "las medidas de bienestar que reducen el sufrimiento son preferibles a no hacer nada desde un punto de vista ético". 132

Consecuentemente, creo que en el ámbito del derecho deberán darse una serie de pasos que lleven hacia este objetivo, la garantía absoluta de una serie de derechos inviolables. El primero de ellos es el reconocimiento por parte de mayor número de legislaciones de la sintiencia de los animales, así como la eliminación de éstos de la categoría de cosas, lo cual abriría la puerta a otra serie de leyes o normas que amplíen el marco de protección de los animales, y sus condiciones de bienestar, hasta el punto en que ya no quepa duda de que el único paso lógico a dar es el reconocimiento de unos derechos básicos inviolables.

En este punto, considero oportuno citar nuevamente a Murcia \& Molano, quienes señalan que

[r]econocer un estatus nuevo que otorgue derechos, en lugar de generar o fortalecer los deberes indirectos que las personas podemos reconocer frente a los animales y el ambiente, es tarea del legislador. Las decisiones judiciales que reconozcan aisladamente derechos, incluso fundamentales, a entidades que entendemos como cosas pueden ser inconvenientes en la medida en que retan la aplicación de la normativa a la que están sujetos tales objetos, como cosas apropiables o bienes bajo la protección del Estado. No queremos decir con esto que la inconveniencia resulte de modificar el Código Civil u otra normatividad, sino que su modificación debe hacerse atendiendo a la afectación o modificación que tendrían distintas normas que dependen de la categoría de sujeto de derecho o cosa $y$, por ello, estas deben ser claramente definidas en sus alcances y consecuencias.

$[\ldots]$

\footnotetext{
${ }^{130}$ SINGER, P. Ethics beyond species and beyond instincts. En NUSSBAUM M. C. \& SUNSTEIN C.R., Animal Rights: Current Debates and New Directions (Oxford 2012) 3

${ }^{131}$ DE SANTANA GORDILHO, H. J. Animal Abolitionism. Habeas Corpus for Great Apes (Salvador 2017) 73

${ }^{132}$ GARNER, R. The Animal Rights Debate: Abolition or Regulation? (New York 2010) 122
} 
Pero si los cambios normativos y sociales nos llevan a esta modificación, es necesario entonces que el legislador tome la tarea definitoria con la seriedad que merece y determine con claridad las características y alcances que tendrían en el sistema normativo los nuevos sujetos de derecho. ${ }^{133}$

Como he dicho, el reconocimiento de la sintiencia de los animales, desde mi punto de vista, no tiene otra consecuencia lógica que el necesario respeto por su vida, y el consecuente reconocimiento y protección jurídica real, es decir, absoluta de ellos. En la medida en que esto debe lograrse paulatinamente, mediante mayor protección y mayores reconocimientos que se den a los animales como seres sintientes, creo que un elemento que puede ser de utilidad y puede tomarse como referente, como punto de partida, es la Declaración Universal de los Derechos de los Animales. Esta declaración, si bien no tiene validez jurídica, señala una serie de derechos de los animales que pueden ser adoptados dentro de las legislaciones de cada país individualmente, como ya se ha hecho en algunos países, entre ellos España ${ }^{134}$, a partir de los cuales se vaya construyendo una estructura robusta y estable de protección jurídica de los animales, que deberá tener como uno de sus elementos centrales la dignidad de aquellos, aspecto que ya se tiene con consideración en la Constitución Suiza ${ }^{135}$, país donde se regula la protección animal ("Tierschutz") expresamente en el artículo 80, y donde se señala específicamente, en el artículo 120, la dignidad de las criaturas vivas. ${ }^{136}$

En cuanto al articulado de dicha declaración, es claro que ella misma no pretende la proscripción del uso de animales en su totalidad por parte del ser humano, tal vez simplemente porque este postulado implica, casi de plano, un rechazo por parte de la gran mayoría de los seres humanos, efecto que, por supuesto, sería contrario a los intereses de protección de los animales. Lo anterior se evidencia, por ejemplo, en el artículo $9^{\circ}$, el cual señala que "Los animales criados para la alimentación deben ser nutridos, alojados, transportados y sacrificados sin causales ni ansiedad ni dolor".

De esta declaración, me parece importante señalar el reconocimiento que hace de los deberes y obligaciones que los humanos, como especie, deberíamos tener de proteger a los demás animales, en vez de estar matándolos sin consideración alguna. La declaración, en sus consideraciones, señala: "que la educación implica enseñar, desde la infancia, a observar, comprender, respetar y amar a los animales" y, posteriormente, el artículo $2^{\circ}$, literal B) dice "El hombre, en tanto que especie animal, no puede atribuirse el derecho a exterminar a los otros animales o explotarlos violando sus derechos. Tiene la obligación de poner sus conocimientos al servicio de los animales". Si bien no comparto todos los elementos de la redacción, me parece muy importante que los seres humanos tomemos consciencia de que nuestra condición de tal debería conllevar un deber de protección por los demás seres, que no son inferiores, sino especialmente vulnerables dada la hegemonía humana.

Por ello, es menester que se reconozca, como en la Declaración Universal de los Derechos del Animal, que los humanos tenemos deberes y obligaciones hacia los animales, aspecto que se menciona, también, en el Convenio Europeo Sobre Protección de Animales de Compañía, aunque en él solo se considere a los animales de compañía. Este convenio señala, en sus consideraciones, que reconoce "que el hombre tiene la obligación moral de respetar a todas las criaturas vivas, y teniendo presentes las especiales relaciones existentes entre el hombre y los animales de compañía" 137 .

De la redacción de los artículos citados de la Declaración Universal de los Derechos del Animal, quizás lo que resulta problemático sea que no debe haber un deber de "enseñar a amar", en la medida en que el deber de respetar a los animales no debe ir aparejado de que haya un sentimiento de amor o afecto hacia los animales. Así como ocurre entre los seres humanos, el respeto no debe existir en la medida en que haya una relación afectiva; el respeto por los derechos del otro debe ser un presupuesto fundamental, más allá de cómo se sienta una persona sobre otra.

\footnotetext{
${ }^{133}$ MURCIA, D. M., \& MOLANO, A. Animales y naturaleza como nuevos sujetos de derecho: un estudio de las decisiones judiciales más relevantes en Colombia, Revista Colombiana de Bioética 13 (2018) 122

${ }^{134}$ CAPACETE GONZÁLEZ, F. J. La Declaración Universal de los Derechos de los Animales. dA.Derecho Animal (Forum of Animal Law Studies) 9/3 (2018) 145. https://doi.org/10.5565/rev/da.339

${ }^{135}$ CAPACETE GONZÁLEZ, F. J., La Declaración Universal de los Derechos de los Animales. dA.Derecho Animal (Forum of Animal Law Studies) 9/3 (2018) 145. https://doi.org/10.5565/rev/da.339

${ }^{136}$ Constitución Federal de Suiza, artículo 120, numeral 2. "La Confederación emitirá reglamentos sobre el manejo de gérmenes y genes de animales, plantas y otros organismos. [La Confederación] Tiene en cuenta la dignidad de la criatura y la seguridad de los humanos, los animales y el medio ambiente y protege la diversidad genética de las especies animales y vegetales". ("Der Bund erlässt Vorschriften über den Umgang mit Keim- und Erbgut von Tieren, Pflanzen und anderen Organismen. Er trägt dabei der Würde der Kreatur sowie der Sicherheit von Mensch, Tier und Umwelt Rechnung und schützt die genetische Vielfalt der Tier- und Pflanzenarten").

${ }^{137}$ Convenio Europeo Sobre Protección de Animales de Compañía. Preámbulo.
} 
Aunque no estoy de acuerdo con algunas conclusiones y planteamientos hechos por Rey Pérez, en el libro Los Derechos de los Animales en serio", coincido con lo dicho por aquel cuando señala que, aunque lo señalado en dicha obra parezca, a priori, irrealizable, no solo por lo arraigadas que están algunas conductas de explotación animal (acudir a zoológicos, consumo de carne, espectáculos etc.) en la gente, sino particularmente "porque los intereses económicos que hay por detrás van a imposibilitar ese cambio de mentalidad y de cultura", la misión debe ser, precisamente, plantear horizontes utópicos "para ir ampliando nuestro círculo moral" $" 138$. Se deben plantear objetivos grandes, se deben plantear retos ambiciosos, si se pretende avanzar en el panorama de los derechos de los animales, teniendo en cuenta que no es panorama sencillo el que se nos presenta.

\section{Consecuencias prácticas que debería tener el reconocimiento de la sintiencia de los animales, en las relaciones entre estos y los seres humanos.}

Como se ha sostenido en este trabajo, el reconocimiento de la sintiencia de los animales, de ser tomado en serio, debe implicar necesariamente el reconocimiento a estos de los derechos a la vida, a la libertad, a la dignidad y a la integridad, a ser tomados como un fin en sí mismos y no como un medio, lo que debería redundar, a su vez, en la abolición de la explotación de los animales en todo sentido por parte del ser humano. Siendo esto una meta que difícilmente puede alcanzarse en el corto y mediano plazo, hay algunos aspectos de la sociedad, en la relación entre humanos y animales no humanos, que, en todo caso, deberían cambiarse sustancialmente, cuando no eliminarse, lo más pronto posible. A continuación, señalaré algunos de estos aspectos, explicando por qué deberían cambiar o cesar, partiendo de los derechos de los animales que se afectan a partir de estos.

Para este efecto, es importante señalar el alcance que debe tener el reconocimiento de cada uno de estos derechos. El derecho a la vida implica el derecho a que esta se les respete, es decir, a no ser privados de ella; como ya se dijo, la sintiencia es un medio por el cual se busca un fin, y ese fin es la existencia continuada, es decir, vivir, y en ese orden de ideas el reconocimiento real de la sintiencia necesariamente debe conllevar un reconocimiento y protección absoluta a la vida de los animales no humanos. El derecho a la libertad es, precisamente, a no ser privados de esta de forma injustificada, a moverse y desarrollarse libremente en su entorno, esto, por supuesto, dentro de ciertos límites, como puede ser, por ejemplo, la propiedad privada de los humanos (que también debería tener límites en el respeto a los entornos de la naturaleza y aquellos espacios que son hábitats propios de los animales no humanos). El derecho a la dignidad implica que los animales sean tratados como un fin y no como un medio y, por tanto, que se respeten sus necesidades físicas y biológicas y no se les explote o utilice como objetos. Finalmente, el derecho a la integridad conlleva el respeto al bienestar físico y psicológico del animal.

Considero que es pertinente hacer algunas apreciaciones adicionales frente a los derechos a la dignidad y a la integridad. Cuando se habla de la dignidad humana, se señala que es un derecho que se reconoce a todos los seres humanos a ser valorados como sujetos individuales y sociales, y que se oponen a esta los tratos degradantes o discriminatorios ${ }^{139}$, y se señala que se trata de "algo que es propio, lo íntimo de cada hombre/mujer, y que no puede ser utilizado como medio, como instrumento, sino que es siempre un fin en sí. Hay algo que provoca repulsión en el intento de poseer integralmente a un hombre como esclavo, a un niño como objeto de placer o a un organismo humano como donador de órganos" ${ }^{140}$. Pues bien, creo que el reconocimiento a la dignidad, a no ser tratado como un medio sino como un fin, debe tener fundamento en la calidad de sintiente de un ser, y no en la especie a la que pertenece. No veo ningún sentido lógico que permita establecer que un animal (el humano) merece ser tratado como un fin por pertenecer a una especie en particular y otros, con los que comparte la calidad de sintiente, no, y creo, entonces, que la dignidad debe ser extendida a los animales en virtud de ser seres sintientes.

Por otro lado, en lo que respecta al derecho a la integridad personal, es relevante recordar lo que señala el artículo $5^{\circ}$ de la Convención Americana sobre Derechos Humanos, a saber: "1. Toda persona tiene derecho a que se respete su integridad física, psíquica y moral. 2. Nadie debe ser sometido a torturas ni a penas o tratos crueles, inhumanos o degradantes. Toda persona privada de libertad será tratada con el respeto debido a la dignidad inherente al ser humano. (...)".

Asimismo, considero pertinente traer a colación lo señalado por la Corte Interamericana de Derechos

\footnotetext{
${ }^{138}$ REY PÉREZ, J. L. Los Derechos de los Animales en Serio (Madrid 2018) 196.

139 UNHCR-ACNUR. Agencia de la ONU para los Refugiados. https://eacnur.org/blog/derechos-humanos-articulo-1tc_alt45664n_o_pstn_o_pst/

${ }^{140}$ VIAL CORREA, J. D., \& RODRÍGUEZ GUERRO, Á. La Dignidad de la persona humana. Desde la fecundación hasta su muerte. Acta Bioethica, 15 (2009) 57
} 
Humanos, en el caso Loayza Tamayo vs Perú, donde expresó que "La infracción del derecho a la integridad física y psíquica de las personas es una clase de violación que tiene diversas connotaciones de grado y que abarca desde la tortura hasta otro tipo de vejámenes o tratos crueles, inhumanos o degradantes cuyas secuelas físicas y psíquicas varían de intensidad según los factores endógenos y exógenos que deberán ser demostrados en cada situación concreta. La Corte Europea de Derechos Humanos ha manifestado que, aún en la ausencia de lesiones, los sufrimientos en el plano físico y moral, acompañados de turbaciones psíquicas durante los interrogatorios, pueden ser considerados como tratos inhumanos."

Creo que este es un derecho que también debe tener como punto de partida la sintiencia, y, en esa medida, también a los animales no humanos se les debe respetar su integridad física, psíquica y moral, lo que, por supuesto, implica que estos no sean sometidos a tratos crueles, que no sean lastimados, ni sometidos a ningún tipo de sufrimiento o vejamen.

En Los Derechos de los Animales en serio, Rey Pérez aborda el tema del reconocimiento de los derechos de los animales, partir de tres categorías diferentes: 1) Derechos de Libertad, 2) Derechos Sociales, y 3 ) Derechos Políticos. En la medida en que yo considero que los derechos de los animales deben tener como fundamento la sintiencia, y difiero con este autor en que se les deba reconocer como co-ciudadanos a los animales, no creo que se les deban reconocer derechos políticos, por cuanto de la sintiencia no se deriva, per se, un interés de los animales que deba ser protegido mediante el reconocimiento de derechos políticos. Sin embargo, en cuanto a los derechos de libertad y derechos sociales que menciona Rey Pérez, creo que estos pueden todos encontrar fundamento en la sintiencia.

En la medida en que los derechos que propongo que deben ser reconocidos a los animales no podrán ser garantizados de forma absoluta inmediatamente, deben tomarse medidas tendientes a alcanzar el reconocimiento absoluto de éstos, de modo que se avance paulatinamente hacia dicha meta. A continuación, señalo algunas de las medidas que considero que deberían ser tomadas partiendo del reconocimiento real de la sintiencia, en aras a alcanzar el objetivo planteado, y a partir de las cuales debería cambiar la forma de relacionarse entre los seres humanos y los animales no humanos, todas las cuales encontrarán sustento en los derechos fundamentales animales que, a su vez, tienen como fuente el reconocimiento de la sintiencia de los animales.

\subsection{Zoológicos}

Los parques zoológicos son y han sido siempre una muestra clara de la violación a la libertad de los animales ${ }^{142}$. La teoría (o excusa), es que los zoológicos desarrollan funciones de protección y conservación de especies, lo que se ve incluso reflejado en instrumentos internacionales, como bien expresa Giménez-Candela cuando señala que: La UE publicó en 1999 una directiva de aplicación general en todos los Estados Miembros, indicando en su preámbulo las finalidades a las que debían servir los Parques Zoológicos, en orden a "la conservación de la fauna silvestre a través de la educación pública, la investigación científica y la conservación de las especies" 143

Sin embargo, la realidad es que estos espacios están diseñados más pensando en la satisfacción de los seres humanos que en la de los animales, como expresa García-Rebollo del Río "Por lo que hace a la labor educativa, si bien algunos parques zoológicos como el de Barcelona han diseñado programas de educación para distintas edades, también lo es que la mayoría de las veces las visitas a estos lugares tienen como finalidad el entretenimiento y la diversión, por lo que la actividad dentro del zoológico se reduce a la simple observación, convirtiéndose el animal no humano en un objeto enjaulado cuyo único fin en este contexto es el de entretener, el de ser observado por las familias que caminan alrededor de las jaulas en su día libre. ${ }^{144}$

En los zoológicos encontramos una gran cantidad de animales encerrados, lejos de sus hábitats naturales y muchas veces totalmente privados de condiciones en las que puedan desarrollarse plenamente, como en el caso tratado previamente del elefante Kaavan. Al respecto, señala Tafalla que:

"Para conocer a los lobos, es más útil un buen documental que muestre su forma de vida, o un buen libro, o un curso impartido en un parque natural, que ver el 'cuerpo' del animal detrás de una verja en una visita al zoo. Lo que nos ofrece el zoo es la belleza de su forma o el colorido de su pelaje, pero eso es solo la superficie del animal, su mero aspecto externo, su apariencia, su imagen. Lo que no nos revelará nunca un zoo, porque su misma estructura lo hace imposible, es lo que el animal realmente es:

\footnotetext{
${ }^{141}$ Corte Interamericana de Derechos Humanos. Caso Loayza Tamayo vs. Perú. Sentencia de 17 de septiembre de 1997.

${ }^{142}$ REY PÉREZ, J. L. Los Derechos de los Animales en Serio (Madrid 2018) 84.

${ }^{143}$ GIMÉNEZ-CANDELA, M. Transición Animal en España. (Valencia 2020) 132

${ }^{144}$ GARCÍA-REBOLLO DEL RÍO, J. J. Hacia un eco-sensocentrismo como postura ética para el derecho animal, en dA.Derecho Animal (Forum of Animal Law Studies) 11/1 (2020) 36. https://doi.org/10.5565/rev/da.477

148 Derecho Animal. Forum of Animal Law Studies, vol. 12/3
} 
cómo se comporta, cómo vive, cómo percibe la realidad, cómo se relaciona con sus congéneres y con otras especies... aún peor, el zoo nos mostrará a menudo comportamientos enfermizos, lo que se llaman estereotipias, propias de animales aburridos y muchas veces incluso profundamente deprimidos.

Los zoos existen, básicamente, por lo mismo que existen las peceras: por razones puramente estéticas, porque nos encanta contemplar animales, y porque encerrarlos nos da la seguridad de tenerlos a nuestra entera disposición, de poder ir a verlos cuando nos apetezca. Los zoos no están diseñados pensando en los animales, sino pensando en nosotros y en el placer estético que sentimos". ${ }^{145}$

Estos lugares representan una violación de los derechos a la libertad, en la medida en que se priva a los animales de ella de forma injustificada, con fines lucrativos o para satisfacción de la curiosidad e interés del humano, tratando así a los animales como un medio y no como un fin en sí mismos, violando entonces, también, el derecho a la dignidad de estos. Adicionalmente, en muchos casos los animales se encuentran en situaciones o condiciones que no son las idóneas para ellos, a veces incluso al punto de llevarlos a sufrir malestar físico y/o psicológico, como ocurría con el elefante Kaavan y los otros animales del zoológico Marghazar, y en estos casos se observa también una violación al derecho a la integridad de los animales.

Los parques zoológicos son una institución anacrónica, que debe cesar de existir, al menos como se conocen hoy en día. Estos, de modo que puedan subsistir, deberían ser simplemente centros de protección y cuidado de especies y/o de individuos que requieran de una protección especial, y no centros lúdicos en los que el ser humano se divierta a partir del cautiverio y explotación de animales. Por supuesto, y estoy de acuerdo con Rey Pérez en esto, no es una opción el cierre inmediato de estos para devolver a todos los animales que los ocupan a sus hábitats naturales, en la medida en que seguramente la gran mayoría no sobreviviría por no tener conocimiento de cómo desenvolverse en dichos hábitats, por lo que el cierre de este tipo de instituciones debería ser cierre paulatino, mientras pueden ser liberados en sus hábitat naturales aquellos que puedan serlo, y encontrarse santuarios para el traslado de los animales que no tengan esta capacidad, y también mientras, idealmente, se transformen estos espacios en santuarios para los animales, cuyo foco sea el animal, y la protección de sus intereses.

\subsection{Experimentación.}

En este ámbito podemos encontrar dos grandes objetivos con los cuales se realizan los experimentos en animales. La experimentación con fines científicos, dentro de la cual enmarcaré también aquella realizada con fines médicos, y la experimentación para el desarrollo de productos cosméticos. Como expresa Singer en Liberación Animal, los animales que son sometidos a experimentación sufren horrores a veces inimaginables, se les somete a procedimientos que les inducen angustia, desesperación, ansiedad, devastación psicológica general y muerte, y muchas veces con una falta de necesidad absoluta en la medida en que se adelantan dichos experimentos, que no ofrecen tampoco garantías en cuanto a mejoras de los sistemas médicos. En ese sentido, señala Singer, "La práctica de la experimentación con animales no humanos tal y como se ha extendido hoy en todo el mundo revela las consecuencias del especismo. Muchos experimentos causan dolores extremos sin que exista la más remota probabilidad de obtener beneficios importantes para los humanos u otros animales". ${ }^{146}$

La experimentación en animales, sea cual sea su finalidad, implica necesariamente una violación a los derechos de los animales, a la vida, en cuanto muchos de estos animales perderán su vida innecesariamente como objetos de la curiosidad humana; a la libertad, en la medida en que están privados de ella durante toda su miserable vida, encerrados en condiciones que no les permiten desarrollarse según sus capacidades ni satisfacer sus necesidades, y sometidos a maltratos físicos y psicológicos constantes, por lo que también se afectan lo que propongo serían sus derechos a la dignidad y a la integridad. La experimentación, entonces, implica una violación de los cuatro derechos que se plantea en este trabajo deben ser reconocidos como mínimos como consecuencia de la sintiencia de los animales.

Ahora bien, en lo que respecta a la experimentación con fines cosméticos, creo que no cabe duda alguna, esta práctica debería cesar en el corto plazo, por no decir de forma inmediata, y debería por supuesto ser declarada ilegal si se reconoce a los animales como seres sintientes. Sobre este punto creo que es fácil encontrar consenso general entre los seres humanos, y esto, creo, ocurre porque de esta práctica no se extrae beneficio alguno que pueda tener una mínima relevancia, y lo único que satisface son los intereses estéticos del ser humano y los económicos de quienes de ello se lucran, los cuales, puestos en una balanza con la vida

145 TAFALLA, M. La apreciación estética de los animales. Consideraciones estéticas y éticas, en Revista de Bioética y Derecho 28 (2013) 81

${ }^{146}$ SINGER, P. Liberación Animal (Madrid 1999) 72. 
de los animales que son explotados no tienen un peso suficiente para que siquiera se plantee la continuidad de estas actividades. Sin embargo, en lo que respecta a la experimentación con fines científicos, especialmente médicos, en cambio, creo que se generan más dudas en los seres humanos sobre la prohibición de la experimentación.

Y es que, en este punto, se encuentran en conflicto los intereses de los humanos y los de los animales no humanos sujetos a la experimentación, cosa que no ocurre con la experimentación cosmética (al menos no intereses que, a mi juicio, puedan tener un mínimo de relevancia para efectos de esta discusión). En la experimentación con fines médicos se ponen en una balanza, en principio, los intereses de los seres humanos y de los animales no humanos que se someten a dichos experimentos y, como es claro, los seres humanos tenemos la tendencia a poner nuestros intereses por encima de los de otros seres sintientes.

Considero, en todo caso, que, si se toma en serio el reconocimiento de la sintiencia animal, eventualmente debe erradicarse la experimentación con fines médicos y científicos en animales, ya que esta, igualmente, implica un desconocimiento de la sintiencia, en el sentido en el que planteo en este trabajo, es decir, aparejada de unos derechos mínimos inviolables. Ahora bien, entiendo que en este caso chocan intereses de los seres humanos que son importantes, como lo son la vida y la salud, pero, reitero, si se toma en serio la sintiencia de los animales, debería tomárseles como fines y no como un medio para proteger la vida de los humanos -que también somos una especie animal sintiente- y que, en lo que respecta al interés de vivir que es inherente a la sintiencia (Francione, 2010, pág. 32), no somos diferentes de los demás animales.

Se suele justificar este tipo de experimentación argumentando que genera un bien a la humanidad, y trae bienestar y salud a los seres humanos, sin embargo, frente a esto, creo que es importante señalar que incluso los descubrimientos más promisorios de la investigación en animales usualmente fallan cuando se hacen pruebas en humanos y rara vez son adoptados en la práctica clínica (según un estudio, incluso menos del $10 \%$ de los descubrimientos científicos altamente promisorios entran en la práctica clínica dentro de los 20 años siguientes), ${ }^{147}$ por lo que considero que en realidad ni siquiera desde un punto de vista utilitarista, como el de Peter Singer, podría justificarse este tipo de experimentación, y es que incluso este autor encuentra complicado que se justifiquen estas prácticas, y señala que "si un solo experimento pudiera curar una enfermedad como la leucemia, ese ensayo sería justificable. Pero en la vida real los beneficios son siempre menos inmediatos e incluso, la mayoría de las veces, inexistentes (...) si realmente fuera posible salvar muchas vidas con un experimento que solo acabara con una y no hubiera ningún otro modo de salvarlas, ese ensayo estaría justificado. Pero se trataría de un caso extremadamente raro". ${ }^{148}$

Con relación a lo señalado por Singer, creo que es pertinente hacer referencia a la cantidad de animales que son utilizados por los humanos y sometidos a experimentación anualmente, para tener una dimensión más clara del problema. Al respecto, señala Leyton que:

en Estados Unidos se usan entre 20 a 25 millones de animales, en toda Europa se usan cerca de 13 millones, en Reino Unido casi 4 millones de animales y en América Latina unos 5 millones de animales no humanos. Existen diferentes criterios para establecer las cifras de animales usados en la investigación: mientras las estadísticas de Reino Unido cuentan a peces y anfibios, en Estados Unidos se excluye expresamente a aves, ratas y ratones, peces y reptiles, los que suman más del $90 \%$ de los animales usados en los laboratorios norteamericanos. En estas estadísticas tampoco aparecen los animales criados en laboratorios que nunca son usados para la experimentación y que son sacrificados como "excedente"; ni los animales muertos para extraer sus fluidos o tejidos biológicos, ni los que son usados en experimentos de largo plazo cuando duran más de un año. Como explican Taylor et al. (2008) muchos países fuera de la Unión Europea no recogen estadísticas de animales usados en experimentos, pues no existe una sistematización ni una obligación legal de disponer públicamente de estadísticas oficiales; o sólo hacen una recogida parcial de estos datos, lo que hace difícil estimar un total de animales usados a nivel global. A pesar de esta diferencia de criterios, en su estudio "Estimates for Worldwide Laboratory Animal Use in 2005" estimaron el uso anual de 115.3 millones de animales en los laboratorios en todo el mundo. ${ }^{149}$

Con esto solo quiero señalar que incluso partiendo de una posición utilitarista es difícil (por no decir imposible) justificar este tipo de experimentación y que, en realidad, la única justificación que tenemos para ella -no válida a mi entender- es el antropocentrismo y, consecuentemente, el especismo. Como expresa Leyton "Las Tres Erres [Reducción, refinamiento y reemplazo] son una solución bienestarista para el

\footnotetext{
${ }^{147}$ British Medical Journal BMJ 2014;348:g3387 doi: 10.1136/bmj.g3387 (Published 30 May 2014)

${ }^{148}$ SINGER, P. Liberación Animal (Madrid 1999) 124.

${ }^{149}$ LEYTON, F. Repensando la bioética de la experimentación con animales desde una perspectiva abolicionista. En FAVRE. D, \& GIMÉNEZ-CANDELA. T, Animales y Derecho (Valencia 2015) 295
}

150 Derecho Animal. Forum of Animal Law Studies, vol. 12/3 
problema ético de la experimentación con animales, pues describen una mejora de las condiciones precarias que encierra un laboratorio para un animal: la privación de libertad y hacinamiento de los animalarios y bioterios, la invasividad de las prácticas, el dolor que los procedimientos causan a los animales, la falta de estímulos ambientales, la falta de relaciones sociales con sus pares, etc. Sin embargo, subsiste el problema moral de fondo que interpela a la ciencia: no existe una práctica científica sin valores. La vivisección existe porque el ser humano se adjudica un valor moral superior, que lo autoriza moralmente a servirse de otros seres vivos para sus propósitos. La ciencia actúa desde una perspectiva antropocéntrica y valora a los animales como meros instrumentos al servicio de una causa superior: el conocimiento, la técnica y la mejora de la vida y el bienestar humano. ${ }^{150}$

En ese orden de ideas, la experimentación con fines médicos y científicos, también es una práctica especista, centrada únicamente en el interés de los humanos y que utiliza a los animales no humanos como un medio, como un objeto, por lo que creo que también debería ser fuertemente regulada y, eventualmente, abolida.

\subsection{Explotación de animales para alimentación y vestido.}

Estos dos pueden ser los aspectos más controversiales, tal vez, en la medida en que implican decisiones del día a día de los seres humanos, y son aspectos sobre los que debe haber un cambio radical.

Detrás de la industria de la producción de alimentos de origen animal, hay un trabajo impecable de mercadeo sobre cómo esconder la verdad, particularmente sobre dos puntos: 1) la forma en que se producen esos productos y 2) la necesidad de consumirlos. Esto se hace necesario, porque -en mi opinión- la mayoría de gente dejaría de consumir muchos de estos productos si tuvieran conocimiento de cómo se producen, de la tortura sistemática de animales que hay detrás de esto. Acá toma importancia el segundo punto sobre el cual se manipula la verdad por parte de estas industrias, es decir, la necesidad de consumir dichos productos.

Mucha gente, incluso conociendo lo que ocurre detrás de estos sistemas crueles de producción puede admitir el consumo de los productos que de estos se obtienen, al considerar que los seres humanos debemos consumirlos para vivir, y para estar saludables, lo cual no es cierto. Hay una gran cantidad de estudios que señalan que los seres humanos podemos sobrevivir y estar perfectamente saludables con una dieta basada en alimentos de origen vegetal durante todas las etapas de nuestra vida, y que incluso este tipo de dietas pueden ayudar a evitar diversas enfermedades ${ }^{151}$. Sin embargo, el trabajo sistemático de propaganda ${ }^{152}$ hace que la gente, en general, crea que ello no es posible y considere que solo se puede ser saludable comiendo alimentos de origen animal. Un ejemplo de ello es la creencia, totalmente generalizada, de que el consumo de proteína equivale exclusivamente al consumo de animales, a pesar de que hay una enorme cantidad de alimentos de origen vegetal que proveen una fuente significativa de proteína.

Hoy en día, en todo caso, esta serie de mentiras se van derrumbando, debido a la facilidad de acceso a la información, lo que permite que las personas accedan a contenido que les muestra lo que hay detrás de la producción de alimentos de origen animal y, además, que se puede estar perfectamente sano (e incluso evitar algunas enfermedades que se relacionan con el consumo de alimentos de origen animal) con una dieta basada en plantas, como se mencionó anteriormente.

Como mencioné anteriormente, este punto representa, tal vez, el conflicto más grande en la relación entre humanos y animales no humanos, en cuanto esta explotación, y en muchos casos tortura, de los animales tiene como fundamento la demanda de productos por parte de los humanos, de modo que cada vez que una persona decide comer algo, toma la decisión (muchas veces no consciente) de participar de la explotación animal, aspecto que, a su vez, tiende a generar conflictos en quienes consumen este tipo de productos cuando se les hace ver esto, por cuanto se evidencia su participación innegable en un sistema de explotación que es cruel e innecesario, lo cual, a su vez, les genera rechazo, puesto que muy difícilmente una persona querrá reconocerse como parte activa, promotora y financiadora de tal sistema. Pero es la realidad. Los seres humanos creemos que los animales tienen un valor moral, y nos oponemos a que se imponga sufrimiento innecesario

\footnotetext{
${ }^{150}$ LEYTON, F. Problemas bioéticos de la experimentación con animales no humanos, en dA. Derecho Animal (Forum of animal Law Studies) 1/3 (2010) 9. https://doi.org/10.5565/rev/da.203

${ }^{151}$ AMIR. M. Canadian Paediatric Society, Community Paediatrics Committee. Vegetarian diets in children and adolescents. Paediatr Child Health 15 (2010) 303-314; AMERICAN DIETETIC ASSOCIATION, Position of the American Dietetic Association and Dietitians of Canada: Vegetarian diets, en Journal of THE AMERICAN DIETETIC ASSOCIATION 103 (2003) 748-765; APPLEBY, P., \& KEY, T., The long-term health of vegetarians and vegans. The future of animal products in the human diet, en Proceedings of the Nutrition Society. Doi:10.1017/S0029665115004334 (2016)

${ }^{152}$ Según la RAE: 1. Acción y efecto de dar a conocer algo con el fin de atraer adeptos o compradores. (...)

3. Asociación cuyo fin es propagar doctrinas, opiniones, etc.
} 
de los animales, pensamos incluso que tenemos la obligación de no imponer sufrimiento innecesario a los animales, y luego procedemos a imponer un sufrimiento inimaginable a millones y millones de animales, sin ningún motivo diferente a nuestro placer, diversión o conveniencia ${ }^{153}$. Como señala Rey Pérez, citando a Dogget y Egan, "a diferencia de respirar o dormir, comer es al mismo tiempo una actividad que necesitamos para sobrevivir y una que rutinariamente plantea cuestiones éticas". ${ }^{154}$

Ahora bien, en cuanto a posibilidad de producir alimentos de origen animal, pero sin maltratar a los animales, considero que, si se toma la sintiencia en serio, esta posibilidad debe descartarse enteramente. Como recuerda Francione, la sintiencia es una adaptación de los animales como medio para alcanzar un fin, que es la vida, la existencia continuada. Matar animales, sin importar si sufren o no, para consumo humano implicaría una violación al derecho a la vida de los animales, carente de todo sustento válido puesto que, como ya se mencionó, los seres humanos no necesitamos alimentos de origen animal para vivir y estar sanos. Por ello, en definitiva, en una sociedad donde se reconoce la sintiencia de los animales, el consumo de su cuerpo o de sus secreciones debe ser erradicado.

Con relación a la industria ganadera y pesquera, Rey Pérez señala que esta "está construida sobre la finalidad de dar muerte a animales que muy habitualmente han llevado una existencia miserable, y son, ciertamente, la principal estructura de nuestro mundo que ataca los derechos de los animales, porque aun cuando respetara, que no lo hace, unas condiciones de vida dignas, acabaría con su sacrificio, con la imposición del máximo mal que es la negación de la vida. Esto nos obliga a los humanos a asumir por lo menos el vegetarianismo como deber moral y debería pasar a convertirse en una obligación jurídica derivada del reconocimiento positivo del derecho a la vida de los animales no humanos". ${ }^{155}$

Como elementos adicionales para esta posición, además de este que es el argumento ético, de respeto por los animales, está también el argumento ambiental, sobre el cual solo escribiré unas breves líneas por cuanto no es el objeto de este estudio.

En efecto, se ha señalado en diversos estudios el gran impacto de la agricultura animal, entre otras razones, por la cantidad de emisiones de gases de efecto invernadero. Así, la FAO ha señalado que esta actividad es responsable del $18 \%$ del total de las emisiones antropogénicas de gases de efecto invernadero de los cinco sectores de mayor impacto, y es responsable del 35-40\% de las emisiones antropogénicas de metano, $65 \%$ de las emisiones antropogénicas de óxido nitroso, y $64 \%$ de las emisiones antropogénicas de amoníaco ${ }^{156}$. Por otro lado, el World Watch Institute expresa que, aunque la FAO señalara en su estudio de 2006 un 18\%, su análisis muestra que la agricultura animal y sus subproductos son responsables de al menos el $51 \%$ de las emisiones de gases de efecto invernadero anuales ${ }^{157}$. Además de esto, otros estudios señalan el gran impacto que ha tenido la ganadería en la deforestación de la Amazonía, Margulis indica que la ganadería es la principal actividad económica asociada a la deforestación de esta selva tropical, al punto que, partiendo del incremento de territorios despejados/deforestados esta zona desde 1970, el $91 \%$ corresponde a áreas que han sido despejadas para explotación ganadera ${ }^{158}$, mientras que Buttler expresó en 2008 que, para ese año, el 62\% del territorio deforestado era utilizado para explotación ganadera ${ }^{159}$.

Por otro lado, la pesca también tiene un gran impacto ambiental. Hay estudios que señalan que El Gran Parche de Basura del Pacífico se compone en más del $46 \%$ de redes de pesca descartadas ${ }^{160}$ (y se trata de una "isla" de basura de 1.6 millones de kilómetros cuadrados de tamaño, aproximadamente), lo que tiene una serie de impactos negativos, como la muerte de animales que intentan alimentarse de estos plásticos, o que se enredan con ellos, e incluso la abundancia de micro plásticos en el agua, que parece reducir la penetración de la radiación solar, lo que afecta el crecimiento de zooplancton y plancton, y que implica, en última instancia, una amenaza o peligro para toda la cadena alimenticia ${ }^{161}$

Finalmente, cabe resaltar otro aspecto que debería incidir en una modificación radical en la forma de producción de alimentos y llevar a la eliminación de productos de origen animal, y es la ineficacia en la

\footnotetext{
${ }^{153}$ CHARLTON, A. \& FRANCIONE, G. Eat like you care: An examination of the morality of eating animals. Exempla Press (2015) 27

${ }^{154}$ REY PÉREZ, J. L. Los Derechos de los Animales en Serio (Madrid 2018) 116.

${ }^{155}$ REY PÉREZ, J. L. Los Derechos de los Animales en Serio (Madrid 2018) 111.

${ }^{156}$ STEINFELD, H. Livestock's Long Shadow (Roma 2006) 112

${ }^{157}$ GOODLAND, R., \& ANHANG, J. Livestock and climate change: what if the key actors in climate change are... cows, pigs, and chickens? (Washington 2009) 111

${ }^{158}$ MARGULIS, S. Causes of Deforestation of the Brazilian Amazon. (Washington 2004) 9

159 BUTTLER. R., en https://news.mongabay.com/2011/09/62-of-deforested-amazon-land-ends-up-as-cattle-pasture/ (última consulta: 26 de septiembre de 2021)

${ }^{160}$ LEBRETON, L. S. Evidence that the Great Pacific Garbage Patch is rapidly accumulating plastic, En Scientific Reports, 8 (2018) 10

${ }^{161}$ ISSITT, M. The Great Pacific Garbage Patch. Salem Press Encyclopedia (2020)
} 
utilización de recursos que repercute en insuficiencia de alimentos para la propia especie humana. Indica Rey Pérez que "el modo de alimentación occidental contribuye a la desigualdad global en el acceso a los recursos y su distribución porque se ha evidenciado que no es un modo de producción de alimentos eficiente por la inversión requerida en agua y consumo de cereales que podrían ir directamente destinados a consumo humano, contribuyéndose así a la desigualdad y a la hambruna en extensas zonas del planeta que son las menos desarrolladas". ${ }^{162}$

Por otro lado, la Humane Society of the United States señala que la agricultura animal industrial no es una opción sostenible en un mundo donde casi mil millones seres humanos no reciben suficiente comida ${ }^{163}$. La eliminación gradual de las instalaciones de confinamiento industrial, en favor de sistemas de agricultura extensiva serán necesarios a medida que la agricultura avance hacia métodos de producción que consuman menos combustibles fósiles. Además, los consumidores deberán reducir su dependencia de la carne, los huevos y la leche, y reemplazarlos con fuentes vegetales de proteínas y otros nutrientes. Sin embargo, los gobiernos y los responsables políticos también deben desempeñar un papel en la creación de una dieta global que pueda alimentar a todos y proteger el medio ambiente. Los fracasos de la agricultura animal industrial, incluyendo su contribución al hambre y las emisiones de gases de efecto invernadero, puede haber sido un efecto involuntario, pero eso no puede negar la apresurada necesidad de pasar a métodos de alimentación ambientalmente más sostenibles y métodos más saludables de producción de alimentos.

Ahora bien, Rey Pérez señala que debemos asumir "por lo menos" el vegetarianismo como deber moral, el cual se distingue del veganismo, al menos a nivel alimentario, en que este último implica una dieta basada en plantas totalmente, es decir, la exclusión de cualquier producto de origen animal. Sin embargo, el mencionado autor señala que "si de lo que estamos hablando es de obtener determinados beneficios de su trabajo o productos derivados de los animales, esto debe hacerse cumpliendo con las condiciones de dignidad que exigen los derechos en el puesto de trabajo. Precisamente, solo puede justificarse la utilización de determinados productos de origen animal (como los huevos o la leche) si se respetan esas condiciones" Esto lo enmarca Rey Pérez dentro de lo que él plantea como unas "sociedades cooperativas mixtas" en las que "[los huevos o la leche] se han obtenido en determinadas condiciones, esto es, por ejemplo, dejando a las vacas pastar por el campo y sin quitarles sus crías o a las gallinas moverse con libertad, siendo además alimentadas en condiciones óptimas para su naturaleza" 165 .

Así como otros planteamientos del autor, la propuesta de este tipo de sociedades cooperativas me parece inaceptable en cuanto, por un lado, su desarrollo implicaría igualmente un trato a los animales como medios y no como un fin en sí mismos, y, por otro lado, no parece ser viable. En el caso de la leche, para que pudiera justificarse tomar la leche sin violar los derechos que emanan de la sintiencia, se haría necesario esperar a que la vaca sea embarazada naturalmente, y no forzadamente por el ser humano (de nuevo, esto sería utilizarla como un medio) y tomar solo la leche que no sea bebida por sus crías. Esto, por supuesto, no es viable si se pretende alimentar a toda la población humana.

En lo que respecta al uso de animales para vestido, considero que este no tiene ninguna justificación. Si bien es cierto que -al igual que la alimentación- en algún punto de la historia y la evolución del ser humano pudo ser necesario debido a las situaciones particulares en que se encontraban nuestros ancestros, ya no lo es. Ahora podemos elegir de una variedad de materiales (al igual que alimentos) de los cuales proveernos para fabricar nuestra ropa sin tener que explotar y/o matar animales para ello. Aunque es cierto que muchos productos sintéticos pueden ser nocivos para el medio ambiente, la realidad es que también hay una enorme cantidad de productos sostenibles y biodegradables que pueden ser utilizados para la producción de ropa, de modo que se proteja el medio ambiente al mismo tiempo que los derechos de los animales.

\subsection{Trabajo animal}

A lo largo de la historia, los animales han desarrollado una amplia gama de funciones y tareas para los humanos y han sido empleados como herramientas para su beneficio, cosa que ocurre aún actualmente. Así, vemos cómo hay animales que se utilizan en vehículos de tracción animal, principalmente en la industria turística, que en el caso particular de Colombia se mantiene como una excepción a la prohibición de uso de animales para estos fines; encontramos también perros utilizados en tareas de seguridad, sea en compañías privadas o en cuerpos de policía, perros lazarillos y animales que hacen parte de procesos terapéuticos, entre

\footnotetext{
${ }^{162}$ REY PÉREZ, J. L., Los Derechos de los Animales en Serio (Madrid 2018) 120.

${ }^{163}$ HUMANE SOCIETY OF THE UNITED STATES., An HSUS Report: The Impact of Industrialized Animal Agriculture on World Hunger, en Environment and human health 6 (2009)

${ }^{164}$ REY PÉREZ, J. L. Los Derechos de los Animales en Serio (Madrid 2018) 111.

${ }^{165}$ REY PÉREZ, J. L. Los Derechos de los Animales en Serio (Madrid 2018) 111.
} 
otros. Así, como señala De Damborenea Martín, “[el reconocimiento científico de la sintiencia de los animales] que en los últimos años se ha convertido en una gran preocupación en una sociedad en la que cada día está más presente la idea de lograr la igualdad y la mejora de las condiciones laborales entre todas las personas, refuerza la necesidad moral y legal de extender este principio también a los animales de trabajo" ${ }^{166}$.

Lo que se plantea acá es una toma de medidas que vayan aumentando la protección de los derechos de los animales paulatinamente hasta alcanzar el reconocimiento pleno de sus derechos a la vida, a la libertad, a la dignidad y a la integridad. Es difícil entrar a analizar ahora cómo debería regularse cada actividad y las medidas que deben tomarse una a una, puesto que hay actividades muy disímiles entre sí en las que se ven envueltos los animales como prestadores de un servicio, que ameritarían, tal vez, un tratamiento particular. No pueden tomarse las mismas medidas frente a los servicios que prestan los perros lazarillos que frente al uso de vehículos de tracción animal, por ejemplo.

Sin embargo, aunque no sea objeto de este trabajo entrar a determinar cómo deben tratarse individualmente estas y otras actividades en las que se utiliza la "mano de obra" de animales, es pertinente hacer algunas precisiones sobre los derechos mínimos que deben respetarse a los animales en el marco de estas relaciones. Este tipo de relaciones, cabe señalar, no creo que puedan enmarcarse dentro de lo que se conoce como relaciones laborales, en la medida en que estas últimas se forjan a partir de un contrato de trabajo, es decir, un acuerdo de voluntades entre dos partes (empleador y un trabajador), acuerdo que, aunque parta de un plano de desigualdad entre quienes lo suscriben, es libre en la medida en que las partes tienen libertad de decidir si se formaliza o no el mismo (no así en las condiciones de aquel, que generalmente son impuestas por el empleador), dando nacimiento, entonces, a una relación laboral.

Valdés Sánchez señala que es importante "distinguir el contrato de trabajo de la relación de trabajo o relación laboral, pues mientras el primero representa el acuerdo o pacto, la segunda constituye su ejecución o materialización, lo que lleva a sostener que es jurídicamente posible la existencia de un contrato de trabajo, por haberse ya celebrado el acuerdo, sin que se concrete en la realidad la relación de trabajo, por no haberse iniciado su ejecución o no llegar a darse nunca la realización de lo convenido. En cambio, la situación opuesta no es posible, porque siempre que se está en presencia de una relación de trabajo se entiende que previamente ha habido un contrato, así solo sea presunto"167.

En ese orden de ideas, es pertinente expresar que los elementos de una relación de trabajo (en Colombia) son la prestación personal del servicio, la subordinación y la retribución, mientras que "los elementos del contrato de trabajo, entendido como el acuerdo de voluntades entre empleador y trabajador, son los mismos de cualquier otro contrato y se concretan en la capacidad, el consentimiento libre de vicios, junto con una causa y un objeto, naturalmente ambos con la condición de licitud"168. Por lo tanto, aunque parecería que tal vez en algunas relaciones entre el humano y los animales no humanos puedan identificarse los elementos de la relación laboral, es claro que no puede hablarse de un contrato, en la medida en que no puede haber un acuerdo de voluntades y, por tanto, no habría un contrato de trabajo que dé origen a una relación laboral propiamente dicha, por lo que entiendo que estas relaciones deben excluirse de plano del ámbito del derecho laboral.

En todo caso, a pesar de que estas relaciones no puedan ser enmarcadas dentro de lo que tradicionalmente se conoce como una relación laboral, quizás los derechos que se reconocen por parte del derecho laboral a los trabajadores sirvan como una base, como un punto de partida, sobre la cual desarrollar los derechos y determinar las condiciones mínimas que deben serle reconocidas a los animales en el desarrollo de estas tareas. Tareas que, en todo caso, deben ser abolidas en el corto o mediano plazo, partiendo de que se trata de relaciones de explotación, y no de aquellas actividades que pueden ser entendidas como parte de una relación mutuamente beneficiosa y enmarcada en el respeto mutuo.

\subsubsection{Salario}

Rey Pérez señala que "el primer requisito de la justicia en un trabajo es el reconocimiento que se obtiene por él. En las sociedades capitalistas, en lo que se refiere a los trabajos productivos, ese reconocimiento ha venido en forma de salario" "169. Por su parte, Valdés Sánchez expresa que el salario, como elemento de la

166 DE DAMBORENEA MARTÍN, P., Derecho y bienestar en animales de trabajo, en Derecho Animal (Forum of Animal Law Studies) 10/3 (2019) 70. https://doi.org/10.5565/rev/da.431

167 VALDÉS SÁNCHEZ, G. G. Derecho Laboral Individual (Bogotá 2019) 85

168 VALDÉS SÁNCHEZ, G. G. Derecho Laboral Individual (Bogotá 2019) 86

${ }^{169}$ REY PÉREZ, J. L. Los Derechos de los Animales en Serio (Madrid 2018) 106 
relación laboral, es "el de mayor interés para el trabajador, pero cuya definición adquiere también una vital importancia para los cálculos financieros del empleador" ${ }^{\prime 170}$.

Una definición de lo que es salario podría necesitar de un amplio análisis, sin embargo, para efectos de este estudio, me limitaré a señalar que, aunque a un trabajador se le hagan multiplicidad de pagos, y todos ellos tengan origen en que este esté prestando un servicio personal, no todos constituyen salario. Así, en Colombia, el artículo 127 del Código Sustantivo del Trabajo define una serie de elementos a tener en cuenta para efectos de determinar si un pago es salario, para lo cual "la norma exige que los mismos tengan la condición de contraprestación directa del servicio, es decir, que entre el esfuerzo invertido en la ejecución de la labor y el pago que recibe el empleado exista una correlación inmediata o una clara equivalencia" ${ }^{171}$.

¿Podemos hablar de un salario para un animal? No lo creo, en la medida en que, como ya he señalado, no hay una relación laboral que emane de un contrato laboral propiamente dicho, simplemente hay una relación de explotación que se le impone por parte de los humanos a un animal no humano. Sin embargo, sí considero que en el marco de estas relaciones debe haber un reconocimiento por ese trabajo o ese servicio que se presta, y este debe estar revestido de esta característica que señalé sobre el salario previamente, es decir, que entre el esfuerzo invertido por el animal y el reconocimiento que se le da haya una clara equivalencia.

Por supuesto, no es posible pensar en darle un monto de dinero a un animal, por lo que este reconocimiento debería ser dado en términos de alimentación saludable, que se ajuste a los estándares veterinarios, y posiblemente en un reconocimiento económico que se entregue al ser humano que esté a cargo del animal, vigilándose que ese ingreso sea efectivamente destinado al bienestar y cuidado del animal ${ }^{172}$.

\subsubsection{Descanso}

Por supuesto, el anterior reconocimiento por sí solo no sería suficiente, en la medida en que lo que se pretende acá es garantizar que los animales que son forzados a realizar tareas para los seres humanos tengan la mayor protección y las mejores condiciones hasta tanto que se logren dar por terminadas estas prácticas. En ese orden de ideas, considero, también es necesario que se regule lo relativo al descanso de los animales, tanto en lo que corresponde a un descanso diario, lo que se haría con una fijación de una jornada máxima, tal como se hace en ámbito del derecho laboral, y también una suerte de "vacaciones", si es que cabe el término.

En ese sentido, considero que para el efecto de la definición de una jornada máxima diaria en que un animal puede prestar servicios debería hacerse, previamente, un estudio de las necesidades y requerimientos particulares de descanso de la especie a la que pertenece el animal. Como indica Camacho Ramírez, "el tiempo en el trabajo ha sido una de las preocupaciones más importantes de la legislación del trabajo e incluso en el primer convenio de la OIT, adoptado en 1919, se limitan las horas de trabajo, buscando garantizar no sólo una elevada productividad, cuanto sobre todo una protección a la salud y a la seguridad de los trabajadores" ${ }^{\text {"173 }}$.

Adicionalmente, es necesario que los encargados del animal dispongan de un lugar en el que este pueda descansar, un lugar que sea apto para su reposo según sus necesidades. Si por las características particulares de un animal este debe tener un tiempo de reposo en medio de la jornada dispuesta para las funciones que realiza, pues debe necesariamente contarse con un lugar adecuado para dicho reposo.

Ahora, como ya se mencionó, no solo es necesario que se reconozca un descanso diario, con la fijación de una jornada máxima, sino que debe concederse un descanso que permita la recuperación del animal del desgaste que se da por la realización de sus tareas durante periodos prolongados de tiempo. En ese sentido, considero que en el marco de este tipo de relaciones también deben reconocérsele a los animales explotados por el humano un régimen de "vacaciones".

Sobre las vacaciones, señala González Charry que "como nueva manifestación del sistema de descanso remunerado, se presenta el de las vacaciones anuales. Aunque [sic] ocurre que el desgaste biológico que sufre el organismo humano al cabo de ocho días de trabajo, es mayor al término de un año de continuas labores. Esto ha dado origen a descanso o vacaciones anuales. Se ha comprobado que, después de un año continuo de trabajo, el organismo necesita descansar para ponerse nuevamente en actitud de proporcionar un trabajo económico rendidor, no solo para la empresa, sino para el empleado, en cuanto a su capacidad para obtener determinado salario. Eso motivó que las leyes sociales establecieran el sistema de las vacaciones

\footnotetext{
${ }^{170}$ VALDÉS SÁNCHEZ, G. G. Derecho Laboral Individual (Bogotá 2019) 273

171 VALDÉS SÁNCHEZ, G. G. Derecho Laboral Individual (Bogotá 2019) 274

172 REY PÉREZ, J. L. Los Derechos de los Animales en Serio (Madrid 2018) 107

${ }^{173}$ CAMACHO RAMÍREZ, A. Tiempo de trabajo y descansos en el ordenamiento de la Unión Europea, En GÓMEZ HOYOS. D. M. Estudios de Derecho del Trabajo y de la Seguridad Social: Origen y perspectivas en los albores del siglo XXI (2014) 412
} 
remuneradas" $" 174$.

Sumado a lo señalado anteriormente, debemos considerar la naturaleza jurídica de las vacaciones, y es que, en Colombia "las vacaciones, según lo ha señalado la jurisprudencia de la Corte Suprema de Justicia, corresponden a un descanso remunerado" 175 . En ese sentido, al igual que ocurre con los humanos, los animales no humanos que se sometan a determinadas tareas o labores, sufrirán un desgaste biológico que se aumentará o se irá acumulando con el transcurso del tiempo, motivo por el cual, a estos, también, deben reconocérseles períodos de descanso remunerado.

Teniendo en cuenta que he señalado que los animales que presten servicios forzados a los seres humanos no devengarían, en sí, un salario sino un reconocimiento, lo que importaría en este caso es que se les reconozca a los animales un descanso acorde con sus necesidades biológicas según la duración de los períodos en los cuales estos se ven obligados a prestar sus servicios, de modo que puedan reponerse plenamente. Durante estos períodos, las personas que se benefician de los servicios de los animales deben encargarse de que dichos reconocimientos (principalmente la alimentación) sigan siendo dados a los animales para garantizar su bienestar en todo momento.

\subsubsection{Representación empresarial}

Así mismo, además de las normas que establezcan estas prescripciones de carácter obligatorio para quienes se beneficien del trabajo de los animales no humanos, es necesario que en las empresas haya un representante de sus intereses. Es claro que la actividad empresarial está guiada principalmente por el interés económico, por un ánimo de lucro, y el respeto por este tipo de normas de bienestar implica costos para el empresario, de modo que esto sería un desincentivo para su uso.

En ese orden de ideas, no puede plantearse que el representante de los intereses de los animales no humanos que son explotados (que parece ser, incluso, contradictorio) sea el empresario o alguien relacionado con este, sino que debe tratarse de un agente externo a la empresa, que tenga conocimientos en zoología, veterinaria e incluso derecho, para que pueda fungir como un legítimo representante de los intereses de los animales ${ }^{176}$.

\subsubsection{Condiciones mínimas en el área/lugar de trabajo}

Es importante que frente al trabajo de los animales se determinen parámetros mínimos que se deben cumplir por parte de quienes se benefician de su uso/explotación, con relación a su bienestar. Como señala De Damborenea Martín, el bienestar animal es un concepto que puede ser garantizado y medido científicamente ${ }^{177}$, por lo que considero es menester que en todo caso en que haya uso o explotación de un animal, que implique el trabajo de éste, quien se beneficie de dicho trabajo deba cumplir con estándares mínimos, y deba demostrar dicho cumplimiento, de forma previa al inicio de las actividades, y sujeto a la verificación e inspección por un ente calificado para ello, con facultades de otorgar los permisos para el uso de animales en ciertas actividades, así como de sancionar a quien los incumpla, e incluso de retirarlos. Finalmente, considero pertinente señalar una serie de requisitos mínimos que deben observarse con relación al trabajo animal, de acuerdo a De Damborenea Martín:

- El acceso a agua y a una alimentación adecuada a las necesidades de cada individuo y siempre en función del tipo de actividad,

- La creación de un entorno de trabajo adecuado, en el que no existan, o traten de reducirse al mínimo, los elementos, bien del propio medio o derivados del tipo de actividad, que puedan generar dolor lesiones o enfermedades en los animales, o que puedan ocasionarles miedo o angustia con motivo de un manejo inadecuado, la incapacidad de controlar el nivel de los estímulos que les rodeen o derivados de la dificultad de las acciones a llevar a cabo.

- La selección de animales que estén en buen estado de salud.

- El acceso a los cuidados de la salud que sean necesarios durante la actividad.

\footnotetext{
${ }^{174}$ GONZÁLEZ CHARRY, G., Derecho laboral colombiano. Relaciones Individuales (Bogotá 2004) 501

175 VALDÉS SÁNCHEZ, G. G. Derecho Laboral Individual (Bogotá 2019) 327

${ }^{176}$ REY PÉREZ, J. L. Los Derechos de los Animales en Serio (Madrid 2018) 113.

177 DE DAMBORENEA MARTÍN, P., Derecho y bienestar en animales de trabajo, en Derecho Animal (Forum of Animal Law Studies) 10/3 (2019) 71. https://doi.org/10.5565/rev/da.431
} 
- El establecimiento de periodos de descanso acordes a sus capacidades y necesidades, en una zona acondicionada para ello" $" 178$.

\subsubsection{Seguridad Social}

Otro de los paralelos que creo debe hacerse entre las relaciones de explotación de los humanos hacia los animales y las relaciones laborales, es el de la seguridad social. En ese sentido, como señala Rey Pérez, "el animal que ha contribuido y que enferma, o que alcanza una edad en la que ya no está en condiciones de hacer lo que venía haciendo, tiene derecho a una jubilación en donde todas sus necesidades de alimentación y atención sanitaria estén cubiertas" ${ }^{\text {179 }}$. Esto implicaría o bien que las personas que se benefician de los servicios de los animales se encarguen directamente de asumir los gastos que esto conlleve, o que se cree una suerte de sistema de seguridad social que cubra estos riesgos para los animales. En este último supuesto, continuando con lo señalado por Rey Pérez, "todo empresario que se beneficie del trabajo de un animal debería cotizar por él, igual que lo hacen por los seres humanos, para que estas aportaciones permitan cubrir los períodos de baja, de jubilación o de incapacidad que los animales no humanos, como los humanos, vivirán a lo largo de su existencia" ${ }^{" 180}$. Sobre este punto particularmente, volveré más adelante.

Los anteriores son algunos de los aspectos en los que considero que deberían hacerse extensivos ciertos elementos que son propios de las relaciones laborales a las relaciones de explotación o uso que hacen algunos humanos de los animales no humanos. Por supuesto, reitero, esto es con miras a alcanzar el objetivo de la abolición de la explotación de los animales no humanos por parte de los humanos, pero teniendo en consideración que no es posible que la misma acabe de un momento a otro. Comprendo, claro, que este tipo de medidas implicarían costos importantes para los empresarios e implicarían grandes cambios en el funcionamiento de la sociedad, pero precisamente ese tipo de costos serían un desincentivo para la explotación de los animales no humanos, del cual se deriva un beneficio exclusivamente para el ser humano. La permisión legal de estas prácticas muestra cómo la ley funge como elemento que perpetúa el especismo y la explotación de los animales.

\subsection{Representación jurídica y democrática de los intereses de los animales.}

Otro aspecto que debería considerarse en el ámbito de la protección de los derechos de los animales es el de la representación jurídica de sus intereses. Aunque, por supuesto, esto varía de un país a otro y según la legislación de cada uno, es importante que haya incentivos o políticas estatales que permitan el reconocimiento y protección judicial de los derechos de los animales. Pienso, por ejemplo, en el Estado de Connecticut, en el cual, en casos de maltrato o crueldad contra perros o gatos, según una ley que rige desde el 2017, la corte puede designar un abogado o un estudiante de derecho para asistirla en el proceso penal anti-crueldad. ${ }^{181}$.

Es importante que los Estados den garantías para facilitar la exigibilidad y el cumplimiento de los derechos de los animales. No basta con señalar una serie de derechos, y establecer consecuencias para quienes violen estos derechos si en realidad no hay forma de hacerlos exigibles, por lo que considero que es necesario que se establezcan mecanismos en los que se facilite la participación ciudadana para legitimar a los seres humanos a acudir a la jurisdicción en casos de violación de los derechos de los animales, en nombre de aquellos, y de forma gratuita, es decir, que se designen abogados de oficio que adelanten los casos, para lo cual, una buena opción inicialmente puede ser la de acudir a los estudiantes de derecho, como en el ejemplo visto.

En mi opinión, los sistemas democráticos deben tener en cuenta todos los intereses que a ellos están sujetos dentro de una comunidad. En ese sentido, aunque seamos los seres humanos quienes votamos y participamos (en mayor o menor medida) de la democracia a través de diversos medios, no podemos tener en cuenta únicamente nuestros intereses. La democracia tiene que abandonar este enfoque antropocéntrico y pasar a tener en cuenta también los intereses de los animales no humanos; Innerarity señala que:

No estamos ante un problema de cómo gestionar ciertos bienes públicos, sino en medio de un profundo

\footnotetext{
178 DE DAMBORENEA MARTÍN, P., Derecho y bienestar en animales de trabajo, en Derecho Animal (Forum of Animal Law Studies) 10/3 (2019) 72. https://doi.org/10.5565/rev/da.431

${ }^{179}$ REY PÉREZ, J. L. Los Derechos de los Animales en Serio (Madrid 2018) 112.

180 REY PÉREZ, J. L. Los Derechos de los Animales en Serio (Madrid 2018) 112.

181 FAVRE, D. Next Steps for Animal Rights, en dA. Derecho Animal (Forum of Animal Law Studies) 10/1 (2019) 22. https://doi.org/10.5565/rev/da.414
} 
déficit democrático, una verdadera exclusión. Si la naturaleza ha de ser reconocida como sujeto político, representada e incluida, eso quiere decir que la contaminación o la explotación abusiva de la naturaleza no son solo deficiencias de nuestro sistema productivo; también constituyen una verdadera deficiencia democrática y revelan que nuestros sistemas políticos, entendidos como completamente ajenos al entorno natural, han erigido a un sujeto soberano que excluye a otros sujetos no humanos y a la naturaleza, es decir, que no son plenamente democráticos ${ }^{182}$.

Un sistema democrático no puede serlo realmente cuando en el proceso democrático se excluyen de forma arbitraria de la toma de decisiones los intereses de sujetos que se ven afectados por estas, en este caso, los intereses de los animales. Una democracia real, plena, debe incluir los intereses de todos los sujetos a quienes afecta, y no solo los de los seres humanos.

Es preciso, entonces, buscar mecanismos que permitan la inclusión en el proceso democrático de los intereses de los animales no humanos. Rey Pérez señala que "es necesario institucionalizar representantes de los intereses de los animales que puedan tomar parte en los procesos legislativos, en los procedimientos judiciales y en otros muchos ámbitos de la compleja institucionalidad de nuestras democracias" ${ }^{183}$. Esto no quiere decir, por supuesto, que se les dé un voto a los animales no humanos, o que se les concedan escaños en los parlamentos, sino que se tengan en cuenta sus intereses por parte de las instituciones democráticas.

\subsection{Responsabilidad Social Empresarial y el bienestar animal}

En la sociedad actual, las empresas fungen como motores de desarrollo, el cual, en teoría, debería redundar en desarrollo social. Ahora bien, siendo aquellas el eje de gran parte de la actividad humana, por cuanto emplean el trabajo subordinado de los seres humanos, ellas tienen un deber o responsabilidad de contribuir a la sociedad, más allá del aspecto meramente económico.

Ante esto es importante aclarar que "[e]l término responsabilidad es entendido en su concepto empresarial como aquel que tienen las empresas en la sociedad en la que viven. Se trata de un término muy utilizado actualmente pero el concepto del mismo varía según el autor estudiado. Básicamente, se refiere a la contribución activa y voluntaria de las empresas al mejoramiento social, económico y ambiental con el objetivo de mejorar su situación competitiva y de valor añadido. Carroll (1979), la define como "las responsabilidades económicas, sociales y medioambientales de las organizaciones según las expectativas de la sociedad en la que se encuentran." La responsabilidad social corporativa va más allá del cumplimiento de las leyes y las normas puesto que dicho cumplimiento se da por supuesto ya que estas son de obligado cumplimiento" ${ }^{184}$.

En ese sentido, considero que las empresas, como parte de su responsabilidad social deberían incluir el bienestar animal. Es decir, las empresas deberían adoptar políticas en las que su responsabilidad con la sociedad esté encaminada (entre otras cosas, por supuesto) al mejoramiento del bienestar de los animales. Esto puede hacerse mediante políticas de no uso de productos que tengan componentes de origen animal, o que aquellas empresas en las que se ofrece un servicio de comedor o que se ofrezca cualquier tipo de alimentación para sus trabajadores, se eviten los productos de origen animal. Todo esto, debe darse acompañado de componentes educativos en los que se indiquen los motivos por los cuáles el consumo de productos de origen animal debe ser desincentivado, dentro de lo que podrían incluirse por supuesto el maltrato y sufrimiento animal y los impactos ambientales que conlleva la producción de productos de origen animal, particularmente la ganadería -la agricultura animal es culpable de más del $90 \%$ de la destrucción de la selva amazónica- ${ }^{185}$ y la pesca. Así mismo, deberían revisarse las prácticas publicitarias de empresas que venden abiertamente productos de origen animal, en la medida en que muestran situaciones falsas de animales felices y libres, que en realidad son explotados sin cesar, y que simplemente engañan al consumidor, produciendo una desconexión con la realidad.

\subsection{Educación}

La educación es, probablemente, uno de los sectores cuyo cambio es crucial para el mejoramiento de las condiciones legales y prácticas de los animales no humanos. No me refiero con esto a educación sobre la

\footnotetext{
182 INNERARITY, D. Una teoría de la democracia compleja. Gobernar en el siglo XXI (Barcelona 2020) 298

${ }^{183}$ REY PÉREZ, J. L. Los Derechos de los Animales en Serio (Madrid 2018) 196

${ }^{184}$ SAJARDO MORENO, A. \& SERRA YOLDI. I. La Responsabilidad Social de las Empresas y la Ciudadanñia Corporativa en la Comunitat Valenciana (Valencia 2008) 18

${ }^{185}$ DE LA PAZ, J. La Revolución Vegana: Por qué y cómo avanzamos hacia la próxima etapa de la historia (2015) 175
} 
biología animal, que sí se incluyen generalmente en los pensum educativos. La educación de los seres humanos, desde pequeños, debería incluir el bienestar animal (así como la responsabilidad ambiental). Sin embargo, ocurre todo lo contrario: es un tema que no se suele abordar con la profundidad e importancia que amerita.

$\mathrm{Al}$ igual que en la publicidad, suelen mostrarse animales felices, y se omite por completo el sufrimiento de aquellos que padecen los efectos de la industria animal. Los humanos crecemos en un mundo en el que se nos "educa" de modo que no hacemos la conexión entre los seres vivos (sintientes) que son los animales y los productos que consumimos, y para el momento en que entendemos que ese producto fue un animal vivo, un ser sintiente (que probablemente llevó una vida de sufrimiento constante), ya no parece importar, y parecería que tiene mayor relevancia placer que nos generan dichos productos, que esas vidas. Se nos forma de modo que terminamos por normalizar la explotación animal. Como señalan Francione y Charlton, educamos a nuestros niños y niñas inculcándoles la idea de que amar a los animales y matarlos es coherente, y que amar a otros es consistente con lastimarlos, esto, es lo que es realmente extremo y realmente triste ${ }^{186}$.

A pesar de lo anterior, parece haber un aumento en la preocupación de los seres humanos por el respeto de la vida y los derechos de los animales. Considero que la educación en este ámbito debe ser una responsabilidad de los colegios, los padres y las universidades, y estas últimas como centros de conocimiento y pensamiento crítico, particularmente, deberían fomentar los estudios relativos a los derechos de los animales, porque se hace necesario en una sociedad en la que la consideración por los demás seres sintientes crece, y precisamente porque las universidades no deben servir simplemente como centros reproducción de información, sino de formación, pensamiento crítico y de progreso social.

En lo que respecta a la enseñanza del derecho animal en las facultades de derecho, la profesora Giménez-Candela señala que "La enseñanza del Derecho Animal, en las Facultades jurídicas es una necesidad que la sociedad demanda y de forma más clara en España a lo largo de la última década, pues abre las puertas al ejercicio de profesiones jurídicas relacionadas con los animales, en una nueva dimensión más conforme a las necesidades de una sociedad que exige un espacio jurídico explícito para los animales y sus relaciones con los seres humanos. La discusión de la situación jurídica de los animales en el Derecho, es a menudo infravalorada en el ámbito jurídico. Sin embargo, hay una abundantísima literatura específica, tanto en el mundo angloamericano como europeo sobre aspectos que son centrales para explicarlos cambios operados en el estatuto jurídico de los animales" $" 187$.

Ciertamente, creo que es de suma importancia que la enseñanza del derecho animal haga parte de las facultades de derecho, en un mundo en el que parece haber una creciente preocupación por el tema, en la medida en que esto puede llevar a que haya abogados que estén preparados para hacer vales los derechos de los animales y, especialmente, juristas con una formación suficiente para la creación de normas y leyes que hagan efectivos estos derechos.

\section{7. ¿Seguridad Social para los animales no humanos?}

Habiendo tratado algunas de las consecuencias que creo que debería tener el reconocimiento jurídico de la sintiencia de los animales, quisiera hacer énfasis en un punto que ya fue tratado anteriormente, a saber, el de la seguridad social para los animales.

Como he señalado, no es posible terminar con la explotación de los animales por parte de los humanos inmediatamente, ni en el corto o mediano plazo, y por ello se hace necesario tomar medidas que lleven paulatinamente a este fin. Así mismo, expresé anteriormente que no todas las relaciones entre humanos y animales no humanos deben considerarse como relaciones de explotación, sino que algunas de ellas pueden ser relaciones o interacciones mutuamente beneficiosas y respetuosas, de acuerdo con lo señalado por Donaldson y Kymlicka.

Pues bien, consideramos que la creación de un sistema de seguridad social para los animales no humanos es una propuesta realizable, que puede ser parte de estas medidas que paulatinamente vayan garantizando los derechos de los animales y pavimentando el terreno para la abolición de la explotación de aquellos, y que podría ser aplicada tanto dentro de las relaciones de explotación animal, como dentro de aquellas que no se enmarcan dentro de esta categoría. Por supuesto, esto no sería realizable con relación a todos los animales, sino solo frente a aquellos que llamamos domésticos. Esto sería un ejemplo de los posibles derechos concedidos a animales ya no solo con base en la sintiencia sino en su relación con los seres humanos.

${ }^{186}$ CHARLTON, A. \& FRANCIONE, G. Eat like you care: An examination of the morality of eating animals. Exempla Press (2015) 130

${ }^{187}$ GIMÉNEZ-CANDELA, M. Transición Animal en España (Valencia 2020) 264 
En este caso, como señala Kymlicka, la justificación es que la domesticación ha hecho que los animales domésticos sean miembros de nuestra sociedad, y que, como tales, tengan otra serie de derechos (membership rights), adicionales a aquellos que se deben a todos los animales sintientes, por cuanto, señala el autor, el reconocimiento de membresía o pertenencia a la sociedad es un componente esencial de justicia para los animales domésticos ${ }^{188}$.

Teniendo esto en cuenta, creo que puede considerarse este sistema de seguridad social para los animales domésticos en dos ámbitos: el ámbito privado y el laboral. Por ámbito privado hago referencia a los animales de compañía, aquellos que conviven con una familia o un ser de la especie humana y, por otro lado, en el ámbito laboral incluyo a aquellos animales que prestan servicios productivos para los humanos.

En primer lugar, me referiré a esta propuesta desde la perspectiva de los animales de compañía, los que, considero, están envueltos en una relación que no puede ser catalogada como de explotación, sino, más bien, una relación entre humanos y animales que puede subsistir en el tiempo, pero que igual debe ser sometida a algunas regulaciones para efectos de garantizar los derechos mínimos inviolables de los animales.

Es ideal que haya un sistema de seguridad social para estos animales en la medida en que esto puede ayudar a que sus necesidades básicas sean cubiertas siempre, y a que se impongan mayores responsabilidades en su cuidado, teniendo en cuenta, por supuesto, que se trata de seres sintientes y no de cosas. Si se reconoce a los animales como seres sintientes, y no como cosas, no podría (ni debería) hablarse de un "propietario" de un animal, sino de un responsable o cuidador.

En el marco de este sistema de seguridad social, todo animal de compañía debería ser registrado y debidamente identificado por parte de la persona responsable ante la entidad administradora del sistema y ésta, con base en la especie, raza y otras características del animal (por supuesto, debe haber una limitación sobre qué especies pueden llegar a ser consideradas como animales de compañía) debería determinar una cuota que se deberá pagar mensualmente por quien sea el cuidador del animal, en representación o a nombre de este. Este dinero sería administrado por la entidad encargada y estaría reservado para pagar o cubrir gastos por contingencias que pueda sufrir el animal (principalmente, de salud).

Las anteriores medidas tendrían dos objetivos: 1) que se identifique plenamente a los animales de compañía y quién es su responsable o cuidador; 2) que el animal tenga cubiertos sus riesgos de salud siempre, en la medida en que muchas veces sus responsables no tienen dinero para poder pagar ciertas medicinas o tratamientos que requieren los animales en momentos específicos, y, 3) intentar que los animales estén bajo el cuidado de humanos que tengan una base económica o recursos suficientes para mantenerlos en condiciones idóneas, en la medida en que el hecho de tener que pagar una cuota o aporte mensual puede funcionar como mecanismo de disuasión sobre adoptar un animal o hacerse responsable de su custodia, máxime si se tiene en cuenta que debe haber una identificación del animal y de su cuidador. En este caso podría considerarse, igualmente, que la cuota tenga relación en alguna medida con los ingresos del cuidador, de modo que se garantice, en alguna medida, una igualdad material con relación a los humanos que funjan como cuidadores o responsables de los animales, puesto que es evidente que no todos los humanos tienen la misma capacidad económica.

Aunque la existencia de un sistema semejante que favorezca a los animales es importante, considero que es mucho más apremiante su implementación en el caso de los animales que están inmersos en relaciones de producción en beneficio de los seres humanos, a las que considero relaciones de explotación, en su gran mayoría. En este caso, quien se beneficiara del trabajo del animal, debería, al igual que en el supuesto anterior, registrar al animal ante la entidad administradora del sistema, y debería pagar mensualmente dos tipos de aportes: 1) aportes a salud, destinados a cubrir cualquier gasto que tenga origen en una enfermedad o accidente que sufra el animal, y 2) aportes a jubilación o retiro del animal, que estarían destinados a cubrir los gastos de vivienda, alimentación y salud del animal una vez deje de prestar sus servicios, bien sea que esto se dé por su edad, o por algún otro motivo que haga imposible la continuidad de la prestación del servicio. Por supuesto, en este caso, el objetivo principal sería proteger la salud y los intereses del animal, pero, además, desincentivar la explotación de animales mediante unas tasas altas, que, en mi opinión, podrían fijarse de acuerdo al capital de la empresa/persona que se beneficia del trabajo del animal y, además, del número de animales que "emplee". Estas tasas deberían aumentar porcentualmente, año a año, en un monto superior (considerablemente) al de la inflación (podrían, también, tenerse en cuenta otros factores) de modo que su pago sea cada vez más oneroso para quien emplee animales.

Por supuesto, una propuesta de esta índole requiere un desarrollo minucioso si se pretende llevar a cabo. Por ahora, la planteamos simplemente como una de las medidas que consideramos que pueden surgir a partir del reconocimiento de la sintiencia de los animales no humanos, tendientes, a su turno, al establecimiento y

${ }^{188}$ KYMLICKA, W. Social Membership: Animal Law Beyond the Property/Personhood Impasse, en Dalhousie Law Journal, 40 (2017) 134 
respeto de sus derechos mínimos y encaminadas, además, a la abolición de las prácticas de explotación a las que son sometidos muchos animales.

Es claro, también, que esta medida solo abarcaría un espectro reducido de los animales que son explotados por los seres humanos (aparte de los animales de compañía, cuyas relaciones con los humanos pueden no enmarcarse como de explotación, necesariamente), pero, así como ocurre con otros proyectos, facilita la apertura del camino de los derechos de los animales, empezando por aquellos que tienen mayor proximidad con el humano, no en su genética, sino en sus relaciones diarias, por lo que creo que pueden tener un nivel de aceptación considerable y es relativamente fácil que se acepten medidas en favor de estos animales por parte del grueso de la población.

\section{Conclusión}

El estudio realizado en este trabajo, por supuesto, no es exhaustivo de la normativa y jurisprudencia colombiana sobre animales, bien sea sobre su protección o sobre su explotación, aunque sin duda permite conocer el panorama general en el país, y muestra un aumento en la preocupación por el bienestar animal en materia jurídica, lo cual es esperanzador en la medida en que, como ya he señalado, la ley va siempre detrás de la realidad, persiguiendo e intentando ajustarse a los cambios científicos y sociales.

En términos generales, creo que estas normas son una muestra de una contradicción evidente. Se reconoce la sintiencia de los animales, y aun así se permite su explotación e, incluso, que se les mate para satisfacer intereses humanos no esenciales (en la medida en que, como ya se expuso, los seres humanos no necesitamos alimentarnos de animales para estar sanos, ni tampoco necesitamos, stricto sensu, nada más que provenga de ellos). De este modo, aunque formalmente se les reconozca como seres sintientes, la realidad es que se les sigue dando el trato de cosas, se les sigue utilizando como medios para conseguir la satisfacción de intereses humanos (a veces, incluso, totalmente superfluos), por lo que en realidad se trata de un reconocimiento incompleto, solo formal. Como señala Kymlicka, no estamos frente a leyes de protección animal, puesto que su propósito no es este, sino que tenemos leyes de uso de animales, y estas normas, en su núcleo, autorizan el maltrato animal ${ }^{189}$. ¿Cuál es el siguiente (y necesario) paso? Un reconocimiento material de esta sintiencia en la que el derecho no se limite a señalar esa condición en una norma, sino a proteger dicha condición debidamente.

Donaldson y Kymlicka expresan que los derechos, por sí mismos, son inertes, y sólo toman relevancia cuando las víctimas de la injusticia se enganchan en una lucha, una resistencia o los reivindican, lo cual parecería sugerir que los derechos animales están destinados a una suerte de inoperancia, y que, incluso en el caso de los derechos humanos, aunque los derechos prometan protección contra determinada clase de humillación, no pueden garantizarla, y, por tanto, sólo cuando los derechos están respaldados por una lucha o contestación políticamente organizada por los oprimidos, pueden atacar la injusticia, por lo que parecería que el prospecto de que los derechos animales garanticen justicia, es mínimo.

Los autores mencionados señalan, considerando lo anterior, que alcanzar derechos legales en el papel es un paso, pero no el fin, de la lucha política. No es claro, añaden, que una política de derechos exitosa requiera necesariamente que sean las víctimas de la injusticia por sí mismas quienes se organicen y se manifiesten, para lo que toman como ejemplo el caso de la reforma sobre trabajo infantil durante la Revolución Industrial en Inglaterra, donde los niños y niñas no tuvieron un rol relevante con relación a la prohibición del trabajo infantil, sino que surgió una coalición que defendió sus intereses en dos momentos, primero, con la formulación inicial de sus derechos, y la subsiguiente lucha para asegurar su implementación efectiva. Este ejemplo, expresan, puede ser un modelo para los derechos de los animales ${ }^{190}$.

Considerando el panorama general, y específicamente el del caso colombiano, encuentro que hay una tendencia creciente por la preocupación o consideración de los animales en el mundo. Esta tendencia puede tener distintas variantes, hay personas interesadas en el bienestar de los animales, otras interesadas en que se les reconozcan derechos, otros simplemente consideran que aquellos no deben ser sometidos a tratos crueles y vejámenes. Sea cual sea el motivo que cada persona pueda tener, lo cierto es que existe esta tendencia y la misma se hace cada vez más visible. Esto tal vez se deba, a la abundancia del material que denuncia estas prácticas, como pueden ser libros o documentales como "Earthlings", "Dominion" o "The Ghosts in our Machine", y a la facilidad creciente de acceso a la información que existe actualmente. Lo cierto es que esta tendencia se manifiesta, cada vez más, en el mundo jurídico, lo que conlleva a que haya más iniciativas tendientes a buscar la protección de los animales en este ámbito.

${ }^{189}$ KYMLICKA, W. Social Membership: Animal Law Beyond the Property/Personhood Impasse, en Dalhousie Law Journal, 40 (2017) 126.

${ }^{190}$ DONALDSON, S., \& KYMLICKA, W. Rights. En GRUEN. L., Critical Terms for Animal Studies (Chicago 2018) 10 
En el derecho es muy importante la certeza, y para que haya certeza se requiere saber de qué se está hablando, es decir, definiciones y delimitaciones de conceptos. Por eso, cuando se aborda el problema o el tema de los animales en el derecho es necesario que haya una definición clara de qué es un animal. Por supuesto, de ello existen definiciones, ya que -como se expuso durante el trabajo- en términos generales los animales han sido clasificados en el mundo del derecho como cosas, y desde ese punto de vista puede creerse, entonces, que ya hay una definición. Sin embargo, de lo que hablo en este momento es de la necesidad de una definición legal que sea acorde con los avances científicos y con la realidad social. Los animales, según estas dos perspectivas, no son cosas, de modo que catalogarlos jurídicamente como tal simplemente no tiene sentido.

La seguridad jurídica es un principio de suma importancia en el derecho, que, en palabras de Ossorio "representa la garantía de la aplicación objetiva de la ley" (2005, pág. 873). Al no haber claridad sobre qué son los animales jurídicamente, no puede haber certeza sobre si estos tienen derechos o no, y, en caso que los tengan, ¿cuáles son esos derechos? No hay parámetros claros sobre los que los jueces puedan decidir los casos que se les presentan, entonces, dos casos similares pueden tener resoluciones completamente diferentes según el juez que estudie el tema. Incluso el mismo caso puede ser interpretado y resuelto de formas totalmente diferentes, como se evidenció en el caso del oso Chucho, en el que al no haber unas premisas básicas a partir de las cuales fundamentar las decisiones, las distintas salas de la Corte Suprema de Justicia llegaron a conclusiones contrarias, no solo en cuanto a la solución en sí del caso, que es algo normal, por cuanto los jueces además de aplicar la ley deben interpretarla, sino sobre los conceptos básicos del caso. ¿Por qué? Porque no hay normas que regulen el tema y no hay conceptos plenamente definidos, lo que vuelve imposible que se aplique de manera objetiva de la ley, y hace demasiado amplio el margen de interpretación judicial. Por tanto, la falta de certeza que hay con relación a la naturaleza jurídica de los animales, redunda en una falta de seguridad jurídica.

Así, como he insistido en páginas anteriores, debe crearse una categoría jurídica nueva, propia, para definir a los animales, separada de las categorías ya existentes y que han representado un obstáculo para su protección real, dado que estos no encajan en ellas. Si bien se han hecho importantes intentos jurisprudenciales para proteger a los animales con base en categorías jurídicas existentes (sujeto de derecho, persona) lo cierto es que el uso de analogías para referirse a los animales denota falencias en el sistema jurídico y muestra la necesidad de un cambio.

Por lo tanto, esta categoría jurídica que se ha de crear para los animales debe tener como punto de partida la sintiencia, y de esta se deben derivar, necesariamente, los derechos mínimos a la vida, a la libertad, a la integridad y a la dignidad de los animales, derechos cuya protección debe ser garantizada por el derecho. A partir de esto, se deberán desarrollar y reconocer otros derechos a los animales según características particulares de las especies a las que pertenezcan, en atención a los diferentes intereses y necesidades que tienen las diferentes especies y, en algunos casos, también en consideración al tipo de relación que tengan los animales con los seres humanos.

Asimismo, el reconocimiento de la sintiencia de los animales, y de esta como condición umbral para la inclusión de los animales dentro del ámbito de consideración moral, así como de los derechos mínimos mencionados, debe tener como consecuencia la eliminación o abolición de la explotación animal en todo sentido, y dado que ello no es realizable en un momento determinado o en el corto plazo, deben tomarse medidas tendientes a garantizar en la mayor medida posible estos derechos, y debe avanzarse de forma progresiva en la protección de aquellos, fortaleciendo cada vez más los mecanismos instituidos para el efecto, hasta que pueda alcanzarse el objetivo de la abolición de la explotación animal.

En lo que respecta al tema de la regulación de los animales en el mundo del derecho, es de suma importancia que las personas que abogan por la protección animal asuman un rol activo, de modo que haya peso y presión cada vez mayor ante un sistema esencialmente especista, con miras a que en la regulación que se expida se tengan en cuenta los intereses de los animales. Debe buscarse el reconocimiento de la sintiencia de los animales dentro del derecho, y a partir de esta se debe edificar la protección de los animales. Habrá otros elementos que sean relevantes, que deban ser tenidos en cuenta, pero creo que es este concepto el que provee una base para la protección de los animales.

Asimismo, la protección a los animales no puede limitarse a mejorar las condiciones en las que son explotados y asesinados. El reconocimiento de la sintiencia propiamente dicho debería conllevar el respeto total de la vida de los animales. Como señalé enfáticamente en este estudio, deben abolirse todas las prácticas de explotación animal por parte de los seres humanos, pero soy consciente de que ello no es viable en la práctica en el corto o mediano plazo y es por ello que creo que, siempre teniendo esa meta clara, deben implementarse medidas progresivas que reduzcan el sufrimiento y mejoren las condiciones de los animales, pero nunca teniendo estas medidas como una finalidad, sino como un camino para llegar a la abolición de esta explotación. 
Sin embargo, como señala Favre, es un error común creer que un conjunto de derechos será reconocido a todos los animales con una legislación que incluya todo. El mundo es complejo y hay muchos asuntos humanos, económicos y culturales en conflicto, por lo que este tipo de medidas, conforme a la naturaleza del derecho, se irán tomando poco a poco, por temas, e irán surgiendo derechos, seguramente, por grupos ${ }^{191}$.

A lo largo del trabajo he expuesto por qué debe haber un reconocimiento jurídico de la sintiencia de los animales no humanos que biológicamente ostenten esa calidad, y por qué este debe implicar también, lógicamente, el reconocimiento de derechos básicos inviolables para esos animales. En ese sentido, he señalado que el reconocimiento formal de la sintiencia, si bien es un paso que debe darse, no es suficiente y que se requiere un reconocimiento material, acompañado de una categorización jurídica propia y apropiada para estos animales, y del cual es parte el reconocimiento de los derechos básicos planteados en este trabajo, y muestro cómo un reconocimiento formal de la sintiencia en términos jurídicos, como en el caso de Colombia, de todos modos permite la explotación de los animales, por lo que se trata de un reconocimiento incompleto.

He señalado que el reconocimiento material de la sintiencia de los animales no puede darse de forma inmediata y que, en ese sentido, deben darse pasos y adoptarse mecanismos que paulatinamente lleven a alcanzar este objetivo, que, a su vez, implica la abolición de la explotación de los animales no humanos, por parte del ser humano. Kymlicka señala que la discusión sobre los derechos de los animales está atrapada en el dilema entre la propiedad y la personalidad, que consiste básicamente en que animales están definidos como objetos y, por lo tanto, como propiedad, y mientras eso sea así las reformas tenderán a ser marginales e ineficaces, pero la alternativa principal a esto es llevar a los animales no humanos a la categoría de persona, lo cual parece políticamente inviable ${ }^{192}$.

Encuentro, entonces, una limitación en la posibilidad de alcanzar en la práctica el reconocimiento material de la sintiencia de los animales no humanos en los términos señalados en este trabajo, por lo que opté por plantear algunos mecanismos prácticos que pueden adoptarse, como son la extrapolación de elementos de las relaciones laborales entre humanos a las relaciones entre algunos animales no humanos y los seres humanos que se benefician de sus servicios, y la creación de un sistema de seguridad social que tenga como beneficiarios a estos animales, propuestas que pueden considerarse como mecanismos para desincentivar la explotación de animales por parte de los seres humanos, en la medida en que, como indiqué en el trabajo, un sistema de incentivos y de cargas que desincentiven la explotación de animales es un medio que considero idóneo para avanzar en el reconocimiento de los derechos de los animales no humanos, en cuanto afectaría los intereses económicos de quienes exploten animales y, por el contrario, fomentaría la exploración de mecanismos alternativos para alcanzar los objetivos que se buscan mediante este tipo de explotación.

A modo de cierre, me gustaría presentar algunas consideraciones por Tom Regan, que encuentro bastante acertadas. Regan señaló que las instituciones injustas no se cambian simplemente organizándolas o limpiándolas. Lo que está fundamentalmente mal con la forma en que los animales son tratados no son los detalles de cada caso, es el sistema en sí mismo. Hay varios ejemplos que son desgarradores. El sufrimiento de los animales utilizados para el consumo humano, la agonía de los animales utilizados para experimentación, la muerte tortuosa y lenta de algunos animales, víctimas de trampas de caza, son ejemplos de ello. Pero lo que está mal propiamente no es el dolor, el sufrimiento, o la privación a la que se les somete. Estos aspectos componen, o son parte de lo que está mal, y lo hacen peor, pero no son el mal fundamental.

El mal fundamental es el sistema que nos permite ver a los animales como nuestros recursos, que nos permite pensar que están para nosotros, para ser comidos, manipulados o explotados. Una vez aceptamos esta visión de los animales como recursos, lo que sigue es tan predecible como lamentable. ¿Por qué preocuparnos por su soledad, su dolor, o su muerte? Si los animales existen para nosotros, para beneficiarnos de una forma u otra, lo que les daña en realidad no importa, o importa sólo cuando empieza a molestarnos, o a hacernos sentir incómodos cuando nos comemos nuestro escalope de ternera, por ejemplo. Así que, sí, saquemos las terneras de su confinamiento solitario, démosles algo más de espacio, un poco de paja y unos compañeros. Pero mantengamos nuestro escalope de ternera ${ }^{193}$.

Esto, evidentemente, no puede ser una medida aceptable. No es posible seguir siendo parte de un sistema que utiliza seres sintientes como bienes. Un sistema en que se cambia la vida por dinero, un sistema que nos enseña a matar y explotar por placer, y a justificarlo. Los seres humanos tenemos un deber moral de cambiar ese sistema injusto, de salir de él, y el derecho, como parte inescindible de nuestra sociedad, deberá

191 FAVRE, D. Next Steps for Animal Rights, en dA. Derecho Animal (Forum of Animal Law Studies) 10/1 (2019) 22. https://doi.org/10.5565/rev/da.414

192 KYMLICKA, W. Social Membership: Animal Law Beyond the Property/Personhood Impasse, en Dalhousie Law Journal, 40 (2017) 125.

${ }^{193}$ REGAN, T., The case for animal rights, en Fox M.W. \& Mickley L.D., Advances in animal welfare science. (Washington 1986) 179 
necesariamente dejar de ser una herramienta de explotación, para pasar a ser parte de ese cambio. Como señala Nussbaum ${ }^{194}$, la verdadera justicia global requiere no solo que miremos a través del mundo en busca de otros miembros de nuestra especie que tienen derecho a una vida decente, requiere también mirar alrededor del mundo a los otros seres sintientes, con cuyas vidas están entrelazadas las nuestras, de forma compleja e inextricable.

\section{Bibliografía}

- ALONSO, E. El artículo 13 del Tratado de Funcionamiento de la Unión Europea: Los animales como seres «sensibles [sentientes]» a la luz de la jurisprudencia del Tribunal de Justicia de la Unión Europea, en FAVRE, D., GIMÉNEZ-CANDELA, T. (Eds.), Animales y Derecho (Valencia 2015) 17-59

- CAMACHO RAMÍREZ, A., Tiempo de trabajo y descansos en el ordenamiento de la Unión Europea, En GÓMEZ HOYOS. D. M., Estudios de Derecho del Trabajo y de la Seguridad Social: Origen y perspectivas en los albores del siglo XXI (2014)

- CAPACETE GONZÁlEZ, F. J., La Declaración Universal de los Derechos de los Animales. dA.Derecho Animal (Forum of Animal Law Studies) 9/3 (2018). https://doi.org/10.5565/rev/da.339

- CHAPOUTHIER, G. From Animal Intelligence to Animal Rights. En FAVRE, D., GIMÉNEZCANDELA, T. (Eds.), Animales y Derecho (Valencia 2015) 136-150

- CHARLTON, A. \& FRANCIONE, G. Eat like you care: An examination of the morality of eating animals. Exempla Press (2015)

- DE DAMBORENEA MARTÍN, P. Derecho y bienestar en animales de trabajo, en Derecho Animal (Forum of Animal Law Studies) 10/3 (2019). https://doi.org/10.5565/rev/da.431

- DE LA PAZ, J. La Revolución Vegana: Por qué y cómo avanzamos hacia la próxima etapa de la historia. Ediciones Vitamina Vegana (2015)

- DE SANTANA GORDILHO, H. J. Animal Abolitionism. Habeas Corpus for Great Apes. (Salvador 2017)

- DONALDSON, S., \& KYMLICKA, W. Zoopolis: A political theory of animal rights (New York 2011)

- DONALDSON, S., \& KYMLICKA, W. (2018). Rights. En L. Gruen, Critical Terms for Animal Studies. University of Chicago Press (2018) 320-336

- FAVRE, D. Animals as living property. En HÄNNI. J., KÜHNE. D. \& MICHEL. M., Animal LawTier und Recht (Zürich 2012)

- FAVRE, D., Next Steps for Animal Rights, en dA. Derecho Animal (Forum of Animal Law Studies) 10/1 (2019). https://doi.org/10.5565/rev/da.414

- FERNÁNDEZ RUIZ, J. Personas Jurídicas de Derecho Público en México, en Boletín Mexicano de Derecho Comparado 89 (1997)

- FERRAJOLI, L. Principia iuris - Teoría del derecho y de la democracia (Madrid 2013)

- FRANCIONE, G. Animal Welfare and the Moral Value of nonhuman Animals. Law, Culture and the Humanities (2010)

- GALIANO MARITAN, G. Reflexiones conceptuales sobre las categorías: Persona, Personalidad, Capacidad y Sujeto de Derecho. Derecho y Cambio Social (2013)

- GARCÍA-REBOLLO DEL RÍO, J. J. Hacia un eco-sensocentrismo como postura ética para el derecho animal, en dA.Derecho Animal (Forum of Animal Law Studies) 11/1 (2020). https://doi.org/10.5565/rev/da.477

- GARNER, R. The Animal Rights Debate: Abolition or Regulation? (New York 2010)

- GIMÉNEZ-CANDELA, M. Transición Animal en España (Valencia 2020)

- GIMÉNEZ-CANDELA, M. Persona y Animal: una aproximación sin prejuicios, dA.Derecho Animal (Forum of Animal Law Studies) 10/1 (2019). https://doi.org/10.5565/rev/da.417

- GONZÁLEZ CHARRY, G., Derecho laboral colombiano. Relaciones Individuales (Bogotá 2004)

- GOODLAND, R., \& ANHANG, J., Livestock and climate change: what if the key actors in climate change are... cows, pigs, and chickens? (Washington 2009)

${ }^{194}$ NUSSBAUM, M. C. Beyond “Compassion and Humanity” Justice for Nonhuman Animals. EN NUSSBAUM M. C. \& SUNSTEIN. C. R., Animal Rights: Current Debates and New Directions (Oxford 2012) 21 
- INNERARITY, D., Una teoría de la democracia compleja. Gobernar en el siglo XXI (Barcelona 2020)

- ISSITT, M., The Great Pacific Garbage Patch. Salem Press Encyclopedia (2020)

- KYMLICKA, W. Social Membership: Animal Law Beyond the Property/Personhood Impasse, en Dalhousie Law Journal, 40 (2017)

- LACHANCE, M. Animals as Sentient Beings: Are we Concerned by Animal Suffering in Canada? En FAVRE. D. \& GIMÉNEZ-CANDELA. T., Animales y Derecho (Valencia 2015) 275-294

- LEBRETON, L. S. Evidence that the Great Pacific Garbage Patch is rapidly accumulating plastic, En Scientific Reports, 8 (2018)

- LEYTON, F. Problemas bioéticos de la experimentación con animales no humanos, en dA. Derecho Animal (Forum of animal Law Studies) 1/3 (2010). https://doi.org/10.5565/rev/da.203

- LEYTON, F. Repensando la bioética de la experimentación con animales desde una perspectiva abolicionista. En FAVRE. D, \& GIMÉNEZ-CANDELA. T, Animales y Derecho. (Valencia 2015) 307-328

- LOW, P. Francis Crick Memorial Conference on Consciousness in Human and non-Human Animals. Cambridge Declaration on Consciousness (Cambridge 2012)

- MARGULIS, S., Causes of Deforestation of the Brazilian Amazon. (Washington 2004)

- MOLANO. A \& MURCIA, D. Animales y naturaleza como nuevos sujetos de derecho: un estudio de las decisiones judiciales más relevantes en Colombia (Bogotá 2018)

- NAVA ESCUDERO, C. Los Animales como Sujetos de Derecho. dA. Derecho Animal (Forum of Animal Law Studies). 10/3 (2019). https://doi.org/10.5565/rev/da.444

- NUSSBAUM, M. C., Beyond "Compassion and Humanity" Justice for Nonhuman Animals. En NUSSBAUM M. C. \& C. R. SUNSTEIN, Animal Rights: Current Debates and New Directions. (Oxford 2012)

- OSSORIO, M. Diccionario de ciencias jurídicas, políticas y sociales (Buenos Aires 2015) 715

- PADILlA, A. Animales no humanos: nuevos sujetos de derecho en el constitucionalismo latinoamericano. En ESTUPIÑAN. L, STORINI. C, MARTÍNEZ. R, \& DE CARVALHO DANTAS. F. A., La naturaleza como sujeto de derechos en el constitucionalismo democrático (Bogotá 2019)

- PEZZETA, S. Una teoría del derecho para los animales no humanos. Aportes para la perspectiva interna del Derecho, en Revista Bioética y Derecho 44 (2018)

- POLLO, S. Animal Welfare, Animal Minds, Animal individuality (2007)

- REGAN, T. The case for animal rights, en Fox M.W. \& Mickley L.D., Advances in animal welfare science. (Washington 1986) 179

- REY PÉREZ, J. L. Los Derechos de los Animales en Serio (Madrid 2018)

- SAJARDO MORENO, A. \& SERRA YOLDI. I. La Responsabilidad Social de las Empresas y la Ciudadanñia Corporativa en la Comunitat Valenciana (Valencia 2008)

- SINGER, P. All Animals are Equal, en Philosophic Exchange, 5 (1974)

- SINGER, P. Liberación Animal (Madrid 1999)

- SINGER, P. Ethics beyond species and beyond instincts. En En NUSSBAUM M. C. \& C. R. SUNSTEIN, Animal Rights: Current Debates and New Directions (Oxford 2012) 3

- STEINFELD, H. Livestock's Long Shadow (Roma 2006)

- SUNSTEIN, C. R. The Rights of Animals, en The University of Chicago Law Review 70 (2003)

- TAFAlla, M. La apreciación estética de los animales. Consideraciones estéticas y éticas, en Revista de Bioética y Derecho 28 (2013)

- VALDÉS SÁNCHEZ, G. G., Derecho Laboral Individual (Bogotá 2019) 85

- VIAL CORREA, J. D., \& RODRÍGUEZ GUERRO. Á. La Dignidad de la persona humana. Desde la fecundación hasta su muerte. Acta Bioethica, 15 (2009) 57

- ZUBIRI, X., La Inteligencia Sentiente (Madrid 1980)

\section{Índice de fuentes}

\section{Fuentes jurídicas}

\section{Legislación}




\section{Legislación colombiana}

- Ley 84 de 1873. Código civil de los Estados Unidos de Colombia. Diario oficial no. 2.867 de 31 de mayo de 1873

- Código Sustantivo del Trabajo, con sus modificaciones, ordenada por el artículo 46 del Decreto ley 3743 de 1950, publicada en el diario oficial no 27.622, del 7 de junio de 1951, compilando los decretos 2663 y 3743 de 1950 y 905 de 1951

- Ley 84 de 1989. Estatuto Nacional de Protección de los Animales. Diario oficial 39.120, diciembre 27 de 1989.

- Decreto 2187 de 2001. Diario oficial no. 44.598, 30 de octubre de 2001

- Ley 769 de 2002. Código nacional de tránsito terrestre. Diario oficial no. 44.932 de 13 de septiembre de 2002

- Decreto 1660 de 2003. Diario oficial no. 45.222, de 18 de junio de 2003

- Decreto 616 de 2006. Diario oficial no. 46.196 de 28 de febrero de 2006

- Decreto 1500 de 2007. Diario oficial no.46.618 de 4 de mayo de 2007

- Decreto reglamentario 1070 de 2015. Decreto único reglamentario del sector defensa. Diario oficial 49.523 de 26 de mayo de 2015

- Decreto 1079 de 2015. Decreto único reglamentario del sector transporte.

- diario oficial no. 49.523 de 26 de mayo de 2015

- Ley 1774 de 2016. Diario oficial no. 49.747 de 6 de enero de 2016

- Decreto 2113 de 2017. Diario oficial no. 50.448 de 15 de diciembre de 2017

- Resolución 136 de 2020. 3 de junio de 2020. Ministerio de agricultura y desarrollo rural.

- Ley 2047 de 2020. Diario oficial no. 51.402 de 10 de agosto de 2020.

\section{Otra legislación}

- Código Civil Federal de México. Publicado en el Diario Oficial de la Federación en cuatro partes, los días 26 de mayo, 14 de julio, 3 y 31 de agosto de 1928

- Constitución Federal de la Confederación Suiza, del 18 de abril de 1999.

\section{Jurisprudencia}

\section{Jurisprudencia colombiana}

- Corte Constitucional. (30 de agosto de 2010) Sentencia C-666 de 2010. [Magistrado Ponente: Humberto Antonio Sierra Porto]

- Corte Constitucional. (1 de febrero de 2017) Sentencia C-041 de 2017. [Magistrado Ponente: Gabriel Eduardo Mendoza Martelo, Jorge Iván Palacio Palacio]

- Corte Suprema De Justicia, Sala De Casación Civil. (26 de julio de 2017) Sentencia ahc4806-2017. [Magistrado Ponente Luis Armando Tolosa Villabona]

- Corte Suprema De Justicia, Sala De Casación Laboral. (16 de agosto de 2017) Sentencia STL126512017. [Magistrado Ponente Fernando Castillo Cadena]

- Corte Suprema De Justicia, Sala De Casación Penal. (10 de octubre de 2017) Sentencia STP165972017. [Magistrado Ponente Fernando León Bolaños]

- Corte Constitucional. (6 de febrero de 2019) Sentencia C-045 de 2019. [Magistrado Ponente Antonio José Lizarazo Ocampo]

- Corte Constitucional. (23 de enero de 2020) comunicado No. 03, sobre la Sentencia SU-016 de 2020.

- Juzgado Primero Penal del Circuito con funciones de conocimiento. (26 de junio de 2020). Sentencia 2020-0047. [Jueza: Isabel Indira Molina]

\section{Otra jurisprudencia}

- Corte Provincial de Loja, Ecuador, Sala Penal. (30 de marzo de 2011) Sentencia 11121-2011-0010. [Juez Ponente: Luis Sempértegui Valdivieso]

- Cámara Federal de Casación Penal, de la Ciudad Autónoma de Buenos Aires, Argentina, Sala II. (18 de diciembre de 2014) Causa CCC68831/2014/CFCI. [Jueces: Alejandro W. Slokar y Ángela E. 
Ledesma]

- Tercer Juzgado de Garantías del Poder Judicial de Mendoza, Argentina. (03 de noviembre de 2016) Expediente 72.254/15. [Jueza María Alejandra Mauricio]

- Alta Corte de Islamabad, Pakistán. (25 de abril de 2020) Petición: 1155/2019. [Juez Athar Minallah]

\section{Instrumentos internacionales y jurisprudencia de órganos internacionales}

- Declaración Universal de los Derechos Humanos de la Organización de Naciones Unidas, Adoptada y proclamada por la Asamblea General en su resolución 217 A (III), de 10 de diciembre de 1948

- Convenio Europeo Sobre Protección de Animales de Compañía, aprobado en Estrasburgo el 13 de noviembre de 1987

- Corte Interamericana de Derechos Humanos. (Sentencia de 17 de septiembre de 1997) Caso Loayza Tamayo vs. Perú.

- Corte Interamericana de Derechos Humanos. (15 de noviembre de 2017). Opinión Consultiva OC23-17

\section{Otras fuentes}

- AMERICAN DIETETIC ASSOCIATION, Position of the American Dietetic Association and Dietitians of Canada: Vegetarian diets, en Journal of THE AMERICAN DIETETIC ASSOCIATION 103 (2003) 748-765

- AMIR. M. Canadian Paediatric Society, Community Paediatrics Committee. Vegetarian diets in children and adolescents. Paediatr Child Health 15 (2010) 303-314

- APPLEBY, P., \& KEY, T. The long-term health of vegetarians and vegans. The future of animal products in the human diet, en Proceedings of the Nutrition Society. Doi:10.1017/S0029665115004334 (2016)

- HUMANE SOCIETY OF THE UNITED STATES., An HSUS Report: The Impact of Industrialized Animal Agriculture on World Hunger, en. Environment and human health 6 (2009)

- BRACKEN, M. \& POUND. P., Is animal research sufficiently evidence based to be a cornerstone of biomedical research?. En British Medical Journal, (2014). Doi: 10.1136/bmj.g3387

- BUTTLER. R., en https://news.mongabay.com/2011/09/62-of-deforested-amazon-land-ends-upas-cattle-pasture/ (última consulta: 26 de septiembre de 2021) 